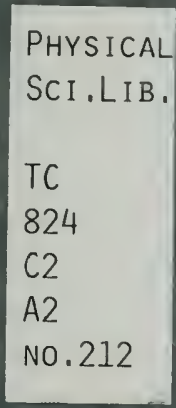



PHISIEAL SCI. IIS.

12
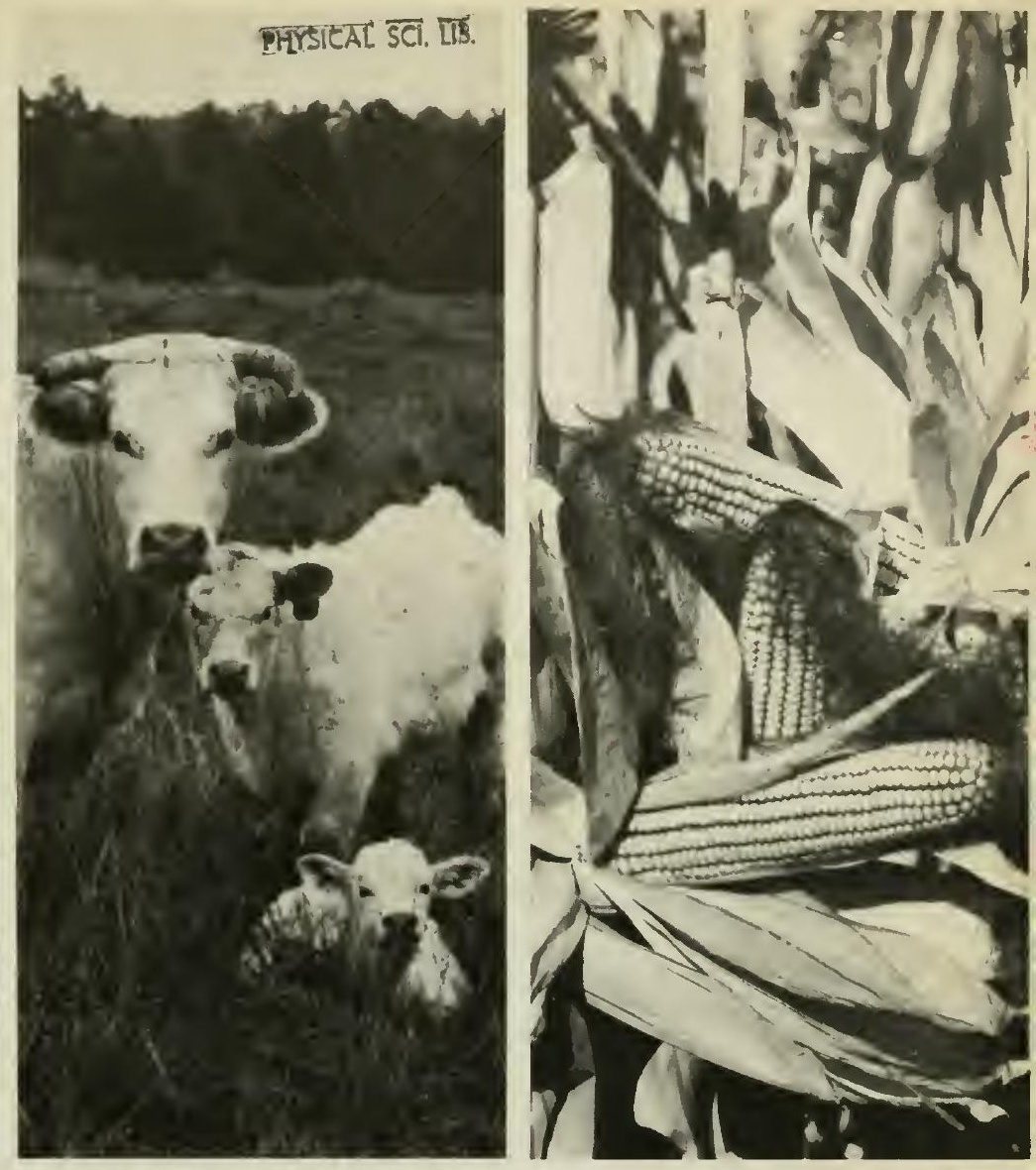

ate of California e Resources Agency

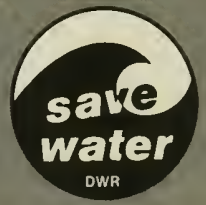

utlook for Water Consumption by talifornia's Feed and Forage ndustry Through 2010 


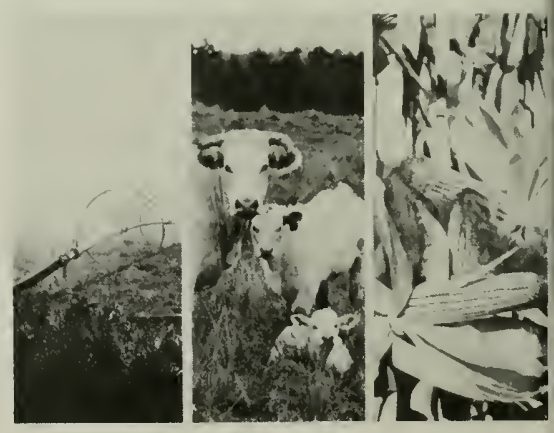

ON THE COVER: Trends in California's livestock and poulfry production will greatly influence the future need for agricultural water in the State. The feed and forage crops grown to feed beef cattle, dairy cows, and poultry require substantial quantities of water. Forecasting this need accurately will require the fullest possible knowledge of the complex interrelationships of crop and animal production. 
Department of

Water Resources

Bulletin 212

\section{Outlook for \\ Water Consumption by California's Feed and Forage Industry Through 2010}

February 1982

Jey D. Johnson

cretary for Resources

ie Resources

yency
Edmund G. Brown Jr. Governor

State of

California
Ronald B. Robie

Director

Department of

Water Resources 



\section{FOREWORD}

California's livestock and poultry production is very closely linked to the consumption of water in California. Raising these animals consumes feed and forage crops that require significant quantities of irrigation water. In the past, the complexities inherent in the physical and economic relationships among livestock production, crop production, and water use have prevented a systematic economic analysis of these factors. A lack of data has been another serious handicap.

In the study reported on here, the Department of Water Resources has developed a simple model that captures some of these complex relationships. Although it is only a beginning, the model provides an approach whereby economic relationships may be quantified.

To serve as a useful analytical tool, a model has certain requirements that must be satisfied. It needs an accurate data set; it must facilitate understanding of the relationships modeled; and it must be confirmed by the expert judgment of others. Ideally, the model should also be verified and cross-checked with independently-produced results derived from other analytical techniques.

In developing the model, the Department made extensive use of outside experts to derive a set of conclusions, using model results as a guide. The study took several approaches to provide methodological and organizational balance. The University of California provided data estimates and analyses, emphasizing feed consumption by animal type, regional costs of production, transportation, processing, and marketing. Independent projections were made by several methods: past production and consumption trends, a balance of likely long-term consumption and animal inventories, and simulation of likely future conditions, based on a mathematical programming model.

At each stage of this study, data and results were reviewed by industry and public representatives who formed an advisory committee. The committee made a fresh assessment of likely future meat and poultry consumption projections developed in the study. In assessing them, the committee took into account changing consumer tastes towards convenience foods; new poultry products recently introduced by grocers, such as turkey ham and turkey 
rolls; and the recent addition of chicken to the menus of many fast food restaurants. Also assessed were possible technological changes in production and marketing that could take place and alter the competitive position of California producers. Thus, significant expert knowledge from many viewpoints helped ensure that the data used, the assumptions made, and the analyses performed were methodologically correct and the results were realistic and reasonable.

We hope that the framework and results presented here will provide the background necessary to understand the relationships involved and to reliably forecast the amounts of water needed to support California's livestock and poultry industries. We also hope that the balanced approach taken in this study will provide an example for future studies of this type.

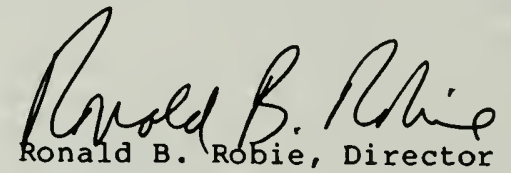

Department of Water Resources The Resources Agency

State of California 
Foreword

Organization, Department of Water Resources

Organization, California Water Commission .

CHAPTER I . STUDY OBJECTIVES AND DESIGN . . . . . . . . . . 1

Introduction. . . . . . . . . . . . . . . . . . . . . 1

Summary of Findings . . . . . . . . . . . . . . . . . . . . . 2

Summary of Recent Conditions . . . . . . . . . . . 2

Land and Water . . . . . . . . . . . . . . . 2

Feed Concentrates. . . . . . . . . . . . . . . 3

Hay and Pasture. . . . . . . . . . . . . . . 3

Livestock and Poultry Products . . . . . . . . . . 4

Summary of Projections . . . . . . . . . . . . 4

Components of the Study . . . . . . . . . . . . . . . 5

Study I. . . . . . . . . . . . . . . . . 5

Study II . . . . . . . . . . . . . . . . . . 6

Study III. . . . . . . . . . . . . . . . . . . 6

Livestock Study Advisory Committee . . . . . . . . 6

CHAPTER II. LITERATURE REVIEW AND METHODOLOGY. • • • • • . 9

Literature Review . . . . . . . . . . . . . . . . . 9 9

Worldwide Crop and Livestock Projection Studies. . . . 9

U. S. Crop and Livestock Projections . . . . . . . . 10

U. S. Livestock Projections. . . . . . . . . . . . 11

California Crop and Livestock Studies. . . . . . . . 11

Methodology . . . . . . . . . . . . 13

CHAPTER III. CURRENT CONSUMPTION AND PRODUCTION TRENDS

AND THEIR RELATIONSHIP TO CALIFORNIA'S WATER

RESOURCES • • • • . . . . . . . .

U. S. Per Capita Consumption. . . . . . . . . . . . . 17

California Animal Numbers and Feed and Forage Crop

Acreage: 1961-1978 . . . . . . . . . . . . . . . .

Feed and Forage Crop Acreage and Water Sources, by Region.

Regions. . . . . . . . . . . . . . . . . . 35

1978 Acreage Percentages by Region . . . . . . . . 35

Acreage and Water Sources by Region. . . . . . . . . 37

Estimated Water Use by Feed and Forage Crops . . . . 39

Crop Water Use Embodied in Feeding Livestock and Poultry. . 
CHAPTER IV. THE LINEAR PROGRAMMING LIVESTOCK MODEL OF THE DEPARTMENT OF WATER RESOURCES . . . . . . .

Purposes of the Complex Model . . . . . . . . . . . . . 43 The Model . . . . . . . . . . . . . . . . . . . . 44

Regions. . . . . . . . . . . . . . . . . . 4 44

Assumptions and Relationships of Major Model Activities, the Objective Function, and the Constraints. Assumptions and Relationships of Activities, the Objective Function, and Constraints Specific to

Land and Water Resources . . . . . . . . . .

1978 Base Run Results . . . . . . . . . . . . . .

CHAPTER V. PROJECTED ASSUMPTIONS AND RESULTS AND SENSITIVITY OF RESULTS FOR 1990, 2000, and 2010 .

Projection Assumptions.

Water Costs. . . . . . . . . . . . . . . 58

Water Conservation . . . . . . . . . . . . . 61

Transportation Costs.................. . 61

Per Capita Consumption . . . . . . . . . . . 62

Projection Results for 1990, 2000, and 2010 . . . . . . 62

Feed Crops . . . . . . . . . . . . . . . . . 64

Forage Crops . . . . . . . . . . . . . . . . 64

Applied Water Use. . . . . . . . . . . . . . 65

Livestock and Poultry Production . . . . . . . . 65

Sensitivity of Projections to Transportation and

Water Costs . . . . . . . . . . . . . . . .

CHAPTER VI. CONCLUDING ASSESSMENT OF STUDY RESULTS • • • . 69

Projections of Applied Water Use. . . . . . . . . . . . . 70

Projections of Livestock and Poultry Production . . . . . . 72

Beef Cattle. . . . . . . . . . . . . . 73

Dairy Cattle... . . . . . . . . . . . . . . . . 74

Poultry. . . . . . . . . . . . . . . . . 75

Projections of Feed and Forage Crop Production. . . . . . . 76

Feed Grains. . . . . . . . . . . . . . . 76

Hay Production . . . . . . . . . . . . . . . . 77

Irrigated Pasture and Rangeland. . . . . . . . . . 77

Factors to Consider in Making Future studies. . . . . . . 79 


\section{Appendixes}

$\underline{\text { Page }}$

A Detailed Model Assumptions and Relationships . . . . 95

Objective Function Costs . . . . . . . . . . 95

Activities in the Matrix . . . . . . . . . . . 95

Constraints. . . . . . . . . . . . . . 100

B The DWR Livestock Model. . . . . . . . . . 101

Tables

11978 Percentages of Selected Feed and Forage Crops

by Region. . . . . . . . . . . . . . . .

Percentages of Selected Feed and Forage Crop Acreage Grown in California in 1975, by water Source....

3 Estimated water Use for Livestock Feed and Forage Crop Production, 1978............... 40

4 Comparison of the 1978 Linear Programming Model Base Run with Reference 1978 Data......... 54

5 Current and Projected Real Typical Water Costs for Linear Programming Model . . . . . . 59 Actual and Projected California Per Capita Demand Levels for Meat, Milk, Poultry and Eggs ... Actual and Projected Feed and Forage Crop Production in California. . . . . . . . . . . . . . Actual and Projected Livestock and Poultry Production in California. . . . . . . . . . . . . . . .

9 Projected Percentage Changes in Feed and Forage Crops from the 1978 Model Base Run . . . . . . . . .

10 Projected Percentage Changes in Livestock and Poultry Production from the 1978 Model Base Run. . . . .

11 California Livestock and Poultry Consumption and Production Projections . . . . . . . . . . . 70

12 Present and Projected Feed and Forage Crops. . . . . 13 Applied Water Use Projections for Feed and Forage Crops ................. . . 72

14 Comparisons of the Linear Programming Model with Trend Extrapolations for California Production .. . . .

151978 Feed and Forage Crop Relationships in the

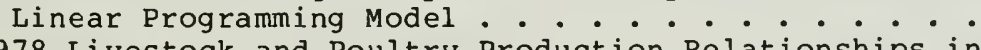

161978 Livestock and Poultry Production Relationships in

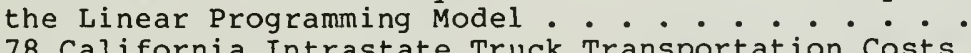

171978 California Intrastate Truck Transportation Costs in the Linear Programming Model. . . . . . . . .

181978 Interstate Truck Transportation Costs in the Linear Programming Model 
1 Livestock and Poultry Feed Crop study Demand and

Supply Projections . . . . . . . . . . . . . . 7

Annual U. S. Per Capita Red Meat Consumption . . . .

Annual U. S. Per Capita Turkey and Chicken Consumption

Annual U. S. Per Capita Meat and Poultry Consumption.

Annual U. S. Per Capita Milk and Egg Consumption . .

Average Annual California Milk Cow Numbers

California Milk production $\quad$.

California Milk Production Per Cow.

California Beef Cow Numbers, January

Annual California Feedlot Marketings

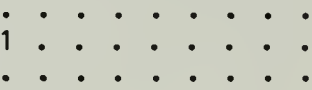

\section{Produced} Annual California Egg Production . . . . . . . . . .

Livestock Industry $\dot{\text { p }} \dot{\text { production and consumption }}$

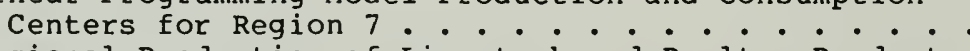

\section{CONTRACT INFORMATION}

Portions of this report were prepared with the assistance of:

\section{Contractor}

U. S. Department of Energy

U. S. Department of Energy University of California
Contract No.

B53139

X51599

B53127
Amount (\$)

$\$ 1,964$

2,000

TOTAL $\frac{18,550}{\$ 22,514}$ 


\author{
STATE OF CALIFORNIA \\ Edmund G. Brown Jr., Governor \\ THE RESOURCES AGENCY \\ Huey D. Johnson, Secretary for Resources \\ DEPARTMENT OF WATER RESOURCES \\ Ronald B. Robie, Director
}

CHARLES R. SHOEMAKER

Deputy Director

MARY ANNE MARK

Deputy Director
M. CATHARINE BERGREN Assistant Director
ROBERT $W$. JAMES

Deputy Director

GERALD H. MERAL Deputy Director

\title{
DIVISION OF PLANNING
}

Donald E. Owen . . . . . . . . . . . . . . . . . Chief

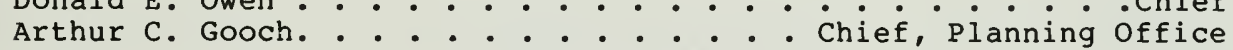
James U. MCDaniel. . . . . Chief, Statewide Planning Branch

This report was prepared by

Joseph C. Fitz . . . . . . Associate Resource Economist

with major assistance from

C. Melvin Warner . . . . . Associate Resource Economist Jeffrey S. Newton. . . . . . . Graduate Student Assistant

and further assistance from

Glenn Sawyer . . . Chief, Water Conservation and Use Section James Wardlow. . . . . . . Senior Land and Water Use Analyst Kenneth Turner. . . . . . Senior Land and Water Use Analyst Paulyne Joe. . . . . . . . . . . . . . . Senior Delineator Travis Latham. . . . . . . . . . . . . Research Writer 


\section{STATE OF CALIFORNIA \\ Department of Water Resources \\ CALIFORNIA WATER COMMISSION}

SCOTT E. FRANKLIN, Chairperson, Newhall THOMAS K. BEARD, Vice Chairperson, Stockton

Roy E. Dodson. . . . . . . . . . . . . San Diego

Alexandra C. Fairless. . . . . . . . . Arcata

Daniel S. Frost. . . . . . . . . . Redding

Merrill R. Goodall . . . . . . . . . . Claremont

Donald L. Hayashi. . . . . . . . . . . . San Franciscc

Charlene H. Orszag . . . . . . . . . . . Sherman Oaks

James E. Shekoyan. . . . . . . . . . . . Fresno

Orville L. Abbott

Executive Officer and Chief Engineer

Tom Y. Fujimoto

Assistant Executive officer

The California Water Commission serves as a policy advisory body body to the Director of Water Resources on all California water resources matters. The nine-member citizen Commission provides a water resources forum for the people of the State, acts as a liaison between the legislative and executive branches of state Government and coordinates Federal, State, and local water resources efforts. 


\section{ACKNOWLEDGMENTS}

The Department of water Resources wishes to express its appreciation for the invaluable assistance granted by many persons during the course of this study. These include several members of the faculty and staff of the University of California, who were particularly instrumental in providing information that was essential to the completion of the study. Charles Goodman and Ed Yeary supplied data on typical crop budgets for regions of California; Donald Bath, John Dunbar, and Dr. Tony Bywater provided data on livestock and poultry production; and Dr. Richard Howitt assisted in the development of the mathematical model used in the study.

Further support from the University came from Dr. Gordon King and Dr. James Cothern, who contributed considerable economic analysis that proved to be of great value to this effort.

Very special recognition is due the members of the Livestock Advisory Committee, whose expert opinions and logical analyses played a key role in projecting many study variables and whose judgments were significant in validating the reasonableness of the study results. These committee members were:

Henry Turner, Chairperson, California Turkey Industry Board

George DeMederios, Dairyman's Cooperative Creamery Association

Dr. Richard Howitt, University of California, Davis

Fran Simpson, California Cattle Feeders Association

William Staiger, California Cattlemen's Association

Hans Van Nes, California Department of Food and Agriculture

Dr. Zachary willey, Environmental Defense Fund

Although the foregoing contributions were of very great value to the Department of Water Resources, the conclusions derived from the findings of this study are those of the Department. 


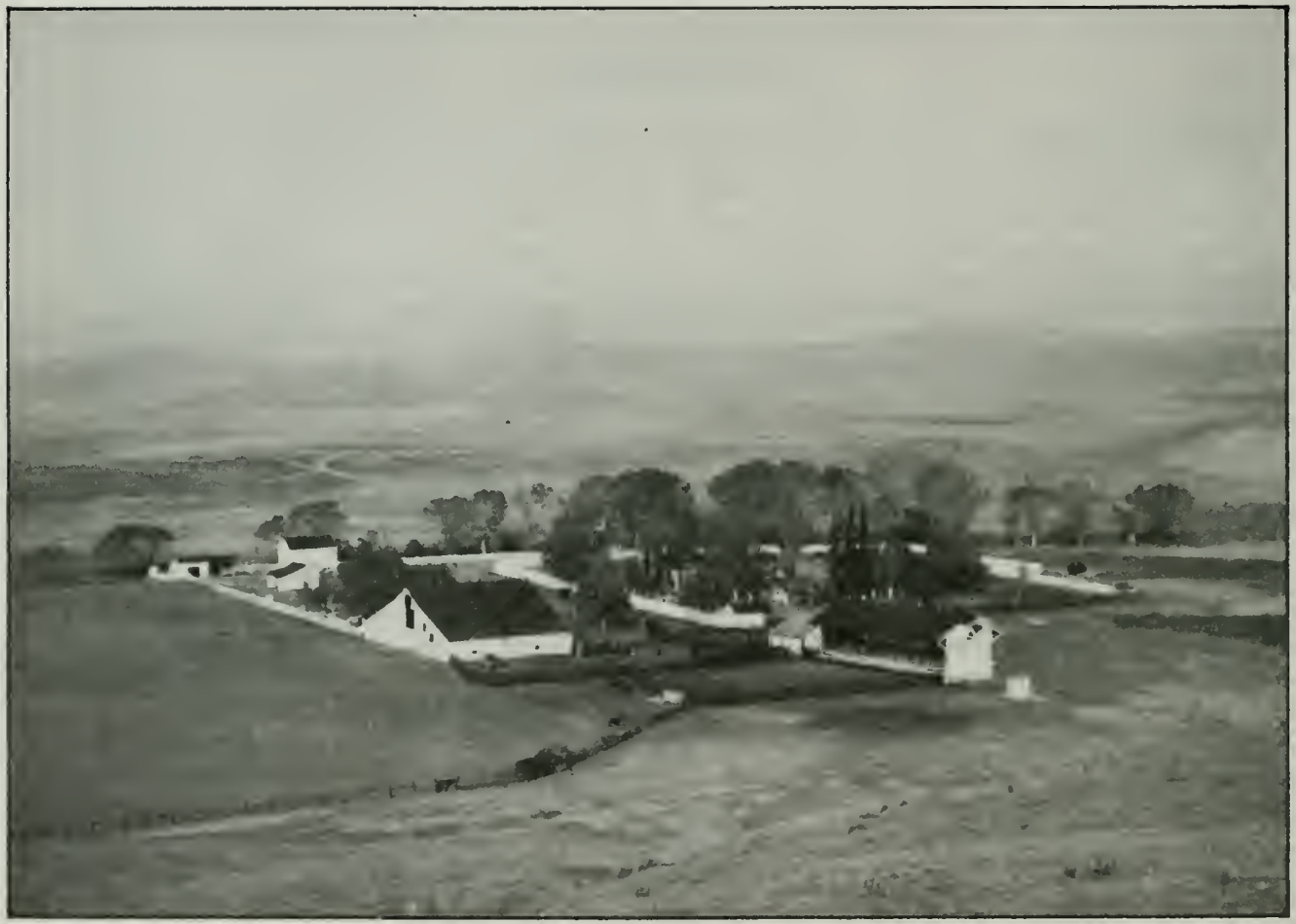

xii 


\section{CHAPTER I \\ STUDY OBJECTIVES AND DESIGN}

\section{Introduction}

California has been long known as a major producer of specialty fruits, nuts, and vegetables. While much attention has been given to these crops in the past, statistics on California production for the past 30 years have revealed that:

- Harvested acres of field crops have consistently represented more than two-thirds of all acreage harvested [26].

- Feed and forage crops have accounted for about 50 percent of these field crop acreages from 1968-78 [18].

- Water use by feed and forage crops was estimated to account for about 42 percent of the total irrigation water applied in 1975 [68].

- Cattle and calf production and milk production have been the two leading commodities in terms of gross income in California for more than 30 years [26].

Given these figures, it is apparent that livestock and poultry and related feed and forage crop production not only figure significantly in California's agricultural economy, but also represent significant quantities of water consumption.

Although the value of California production of cattle and calves is still quite high, in recent years, an increasing proportion of the beef consumed in California has been shipped in from other states. Furthermore, increases in energy costs are likely to increase water and transportation costs in the future more rapidly than the rate at which the overall cost of living

Bracketed numerals identify references listed in the Bibliography. 
increases. These changes, coupled with possible future changes in consumer tastes or a slowdown in the growth rate of beef consumption per capita, may influence future acreages of feed and forage crops and numbers of livestock and poultry produced in California in the future.

The importance of these potential impacts, particularly energy cost increases, on water consumption projections by the Department of Water Resources (DWR) was recognized by DWR in 1977,- at which time the Department pointed out the importance of studying the effects of energy costs on the livestock and feed and forage industries.

The purpose of this study is to estimate projections of likely numbers of livestock and poultry to be produced in 1990, 2000 , and 2010 in California and their resulting land and water requirements, in view of:

- California's competitive position in livestock, poultry, and grain production, with respect to other states.

- Estimated future water costs in California and other states.

- Estimated future transportation costs in California and other states.

- Estimated future consumer tastes and preferences in California and other states.

\section{Summary of Findings}

\section{Summary of Recent Conditions}

The complex relationships between livestock and poultry production and 1 and and water use are summarized in the following section. These relationships are detailed in a University of California publication (68) from which much of the data used in the study reported here were obtained.

\section{Land and water}

(1) In 1975, a total of about $39.1 \mathrm{million}$ cubic dekametres 31.7 million acre-feet) of water was used for irrigated agriculture. Of this amount, about $16.6 \cdot \mathrm{million}$ cubic dekametres (13.5 million acre-feet), or 42 percent, was used to produce livestock feed, including grain ( 8 percent), hay (18 percent), and irrigated pasture (16 percent).

1/ Kenneth M. Turner, Feed and Forage Crop projections: Review and Analysis, Office Report, Department of Water Resources, 1977. 
(2) Land allocated to production of livestock feed in 1975 included 674,800 hectares $(1,665,000$ acres) of grain; 667,800 hectares $(1,650,000$ acres) of hay; 485,600 hectares $(1,200,000$ acres) of irrigated pasture; and 14,555,900 hectares $(35,968,000$ acres $)$ of rangeland.

(3) The 1975 irrigated acreage for livestock feed is estimated at $1,469,800$ hectares $(3,632,000$ acres $)$, or 41 percent of the total irrigated area in the state.

Feed Concentrates

(1) Livestock and poultry used an average of 7.8 million megagrams ( 8.7 million tons) of feed concentrates annually from 1974 through 1976 and $6.3 \mathrm{million}$ megagrams $(7.0 \mathrm{million}$ tons) annually from 1961 through 1965, an increase of 24 percent that was made up about equally of grain and by-product feeds.

(2) Shipments of feed grain concentrates into California and local statewide production in the 1974-1976 period each contributed about 50 percent of California's total feed grain supply.

(3) By-product feed production has increased during the past two decades, as have in-shipments of such feeds as soybean meal and molasses.

(4) In the 1974-1976 period, beef cattle and poultry each consumed about 2.7 million megagrams $(3.0$ million tons) of feed concentrates and dairy cattle, about 2.2 million megagrams (2.4 million tons). Only minor amounts were used for hog and sheep production.

Hay and Pasture

(1) Alfalfa hay production averaged 6.1 million megagrams ( 6.7 million tons) from 1974 through 1976, and production of other hay, $0.6 \mathrm{million}$ megagrams $(0.7 \mathrm{million}$ tons). This demonstrates a three-percent increase in total hay production since the 1961-1965 period.

(2) In the 1974-1976 period, irrigated pasture and alfalfa hay used about 75 percent of the irrigation water applied to california crops grown to feed poultry and livestock.

(3) In 1975 about one percent of the State's pasture and alfalfa acreage was irrigated with state Water Project water. Fourteen percent was grown with water from the U. S. Bureau of Reclamation; 31 percent, with local surface water; and 54 percent, with ground water [62].

(4) Dairy cattle used 5.4 million megagrams $(5.9$ million tons) of hay annually ( 66 percent); beef cattle, 1.8 million megagrams 
( 2.0 million tons), ( 22 percent); and horses, about $0.9 \mathrm{mil}-$ lion megagrams ( $1.0 \mathrm{million}$ tons), ( 11 percent). Only minor amounts of hay were used for sheep and lambs.

(5) Dairy cows consumed approximately 75 percent of the alfalfa produced from 1974 through 1976.

(6) Irrigated pasture and rangeland contributed an estimated 26.5 million animal unit months of grazing in the 1974-1976 period. Beef cattle represent 74 percent; dairy cattle, 16 percent; and sheep and lambs, 10 percent.

(7) Of the $26.5 \mathrm{million}$ animal unit months of grazing produced in California in the 1974-1976 period, about half were produced from rangeland and about half from irrigated pasture.

\section{Livestock and Poultry Products}

(1) U. S. consumers presently allocate almost half their at-home food expenditures for 1 ivestock and poultry products. Expenditures on individual commodities may vary over time, as changes take place in prices, real income levels, and personal tastes and preferences.

(2) California production of lamb, eggs, and turkey meets or exceeds local consumption of these products. Other regions, however, provide an estimated 42 percent of beef consumed in the state, 98 percent of the pork, and about 60 percent of the poultry meat. Some dairy products, such as cheese, may be shipped into California, but consumption of most dairy products is met from local production.

Summary of Projections

Forecasts of levels of production of livestock and poultry products and associated 1 and and water use, presented in Tables 11,13 and 14 of Chapter VI, are summarized as follows:

(1) The rate of increase in beef consumption per capita will gradually taper off; consumption per capita in 2010 is projected to be only 8 percent higher than 1975-1977 levels.

(2) Poultry production and consumption in California are projected to increase rapidly, roughly doubling 1976-1978 levels by 2010 .

(3) Feedlot marketings in California appear likely to continue their downward trend, although the trend will level off. Feedlot marketings in 2010 are projected to be close to 1976-1978 levels. An increasing portion of beef consumed in California will continue to come from other states. 
(4) Milk production per cow will probably continue to increase, but not at the levels of recent years. Milk cow numbers in 2010 are expected to be 95 percent of 1976-1978 levels.

(5) Results of the study indicate that alfalfa hay, irrigated pasture, and feed grain acreage in 2010 will about equal 1976-1978 levels. The shifts to more corn and wheat production and less barley and sorghum production are expected to continue in the feed grains group.

(6) Improved irrigation management will probably reduce applied water use per crop by 10 percent in 2010. Overall applied water use for feed crops is projected to decline by 10 percent from 1976-1978 levels by 2010, principally as a result of the improved irrigation management.

These projections represent our best estimates of what most probably will happen under assumed future economic, institutional, or other conditions. Any major changes in these conditions could have a major impact on the foregoing projections.

Components of the study

Three separate investigations were conducted for this study. They covered (1) trends of feed and forage crop and livestock production, (2) California's likely comparative advantage and livestock and poultry production projections to 1990 and 2000 , and (3) crop and livestock and associated water use projections to 1990,2000 , and 2010 . The performance and results of the third investigation compose this report.

In 1977, DWR economists interviewed a number of representatives of the livestock, poultry, and feed and forage crop industries, as well as consumer and environmental groups. Tabulation and summary of the information obtained in these interviews provided:

- A description of the problems the interviewees felt were facing California producers and what the future would hold for the producers.

- Ways in which DWR should conduct this study [29].

Based on this information and the Department's views on the best use of its resources and staff, the plan for the study was outlined in the following manner:

Study I

Study I would be conducted jointly by DWR economists and University of California's agricultural economists and animal scientists, whose combined expertise would produce an updated feed balance study and assess trends in livestock, poultry, and feed and forage crop production. Accordingly, in the fall of 1978, a 
letter of agreement was signed between the University of California and the Department of Water Resources. A final report on this has been published [68].

Study II

A second study to be conducted by the Cooperative Extension Service of the University of California, Davis, would look closely at California's likely comparative position with respect to other states, using the most recent data available, and assess a recent set of 1985 California projections [67], and project meat and poultry consumption and production to 2000 . Study II would also consider likely impacts of energy cost increases on California's competitive position, with respect to other states. The University and the Department signed a contract for this study in December 1978, and a draft report containing the results of the work was submitted to the Department in July 1980.

Study III

Study III, the investigation reported in this bulletin, was to be conducted by the Department of Water Resources.

In carrying out this study, a literature search was made first to determine the appropriate methodology to use in making projections. Next, relying heavily on data assembled in the two preceding studies and given population projections, a linear programming model was developed to assess the likely impacts to California producers on changes in production, transportation, and water costs in meeting estimated future consumption levels. Using the model results, the conclusions of the first two studies, and the judgment of the Advisory Committee (formed in 1978), a set of likely production and consumption patterns was projected to 1990 , 2000, and 2010. These projections were made independently of those in Study II. The model generated optimal production locations, given costs of production, costs of transportation and resource and market constraints. Costs of land, water, feed and forage crop production, livestock and poultry production, transportation, and slaughter were considered. Figure 1 shows the major components of the study.

\section{Livestock Study Advisory Committee}

An Advisory Committee formed in the fall of 1978 to guide these three studies met several times during the course of the work. (The members are listed in the Acknowledgements, page xi.)

The committee assessed the historical data compiled and provided guidance for the projections. The final set of projections summarized in this study considers the projections made in Study II, the linear programming model projections of Study III, and the professional judgment of the committee. 


\section{Figure 1. LIVESTOCK AND POULTRY CROP STUDY DEMAND AND SUPPLY PROJECTIONS}
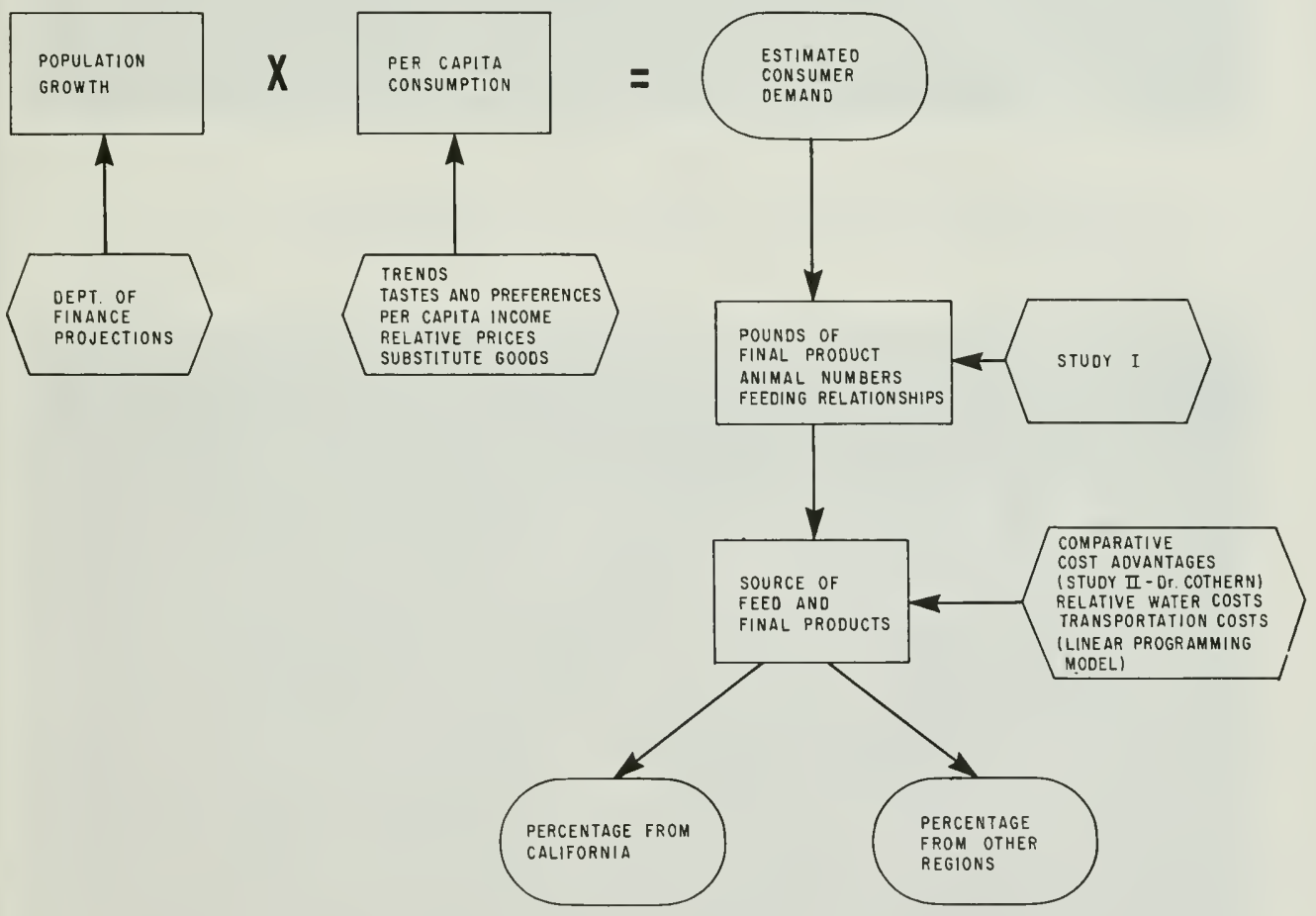


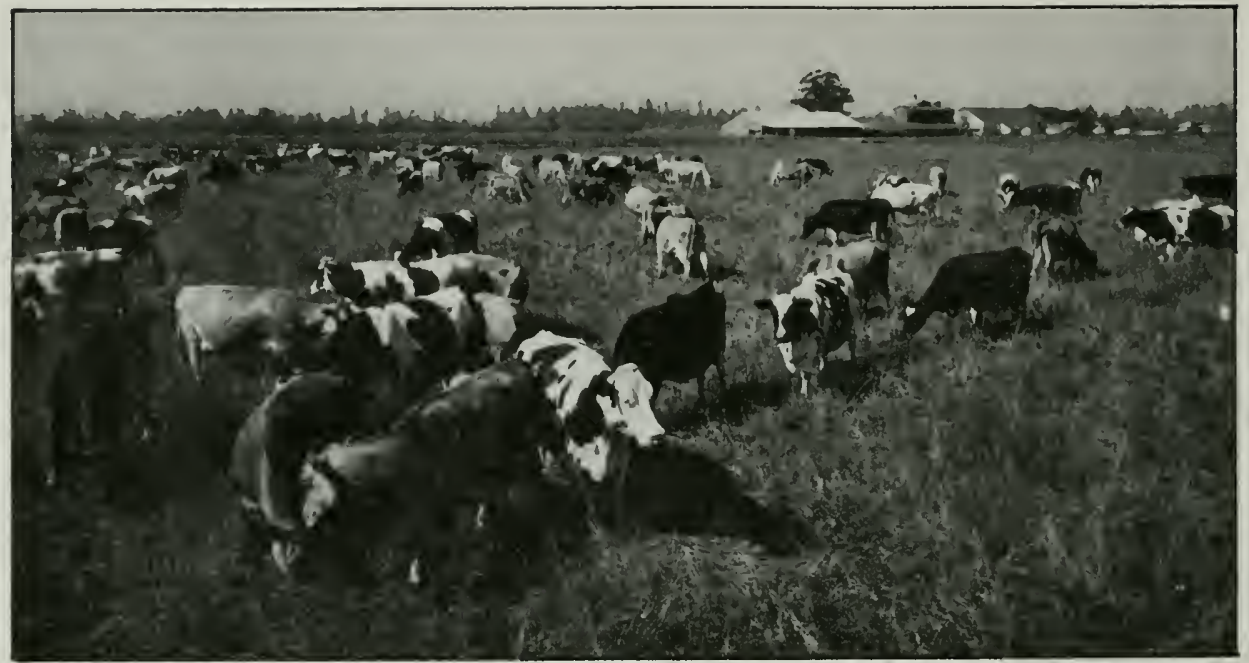

The dairy industry in California is an indirect user of important amounts of water. Dairy cows are the major consumers of irrigated pasture and eat about three-fourths of the alfalfa hay grown in the state.

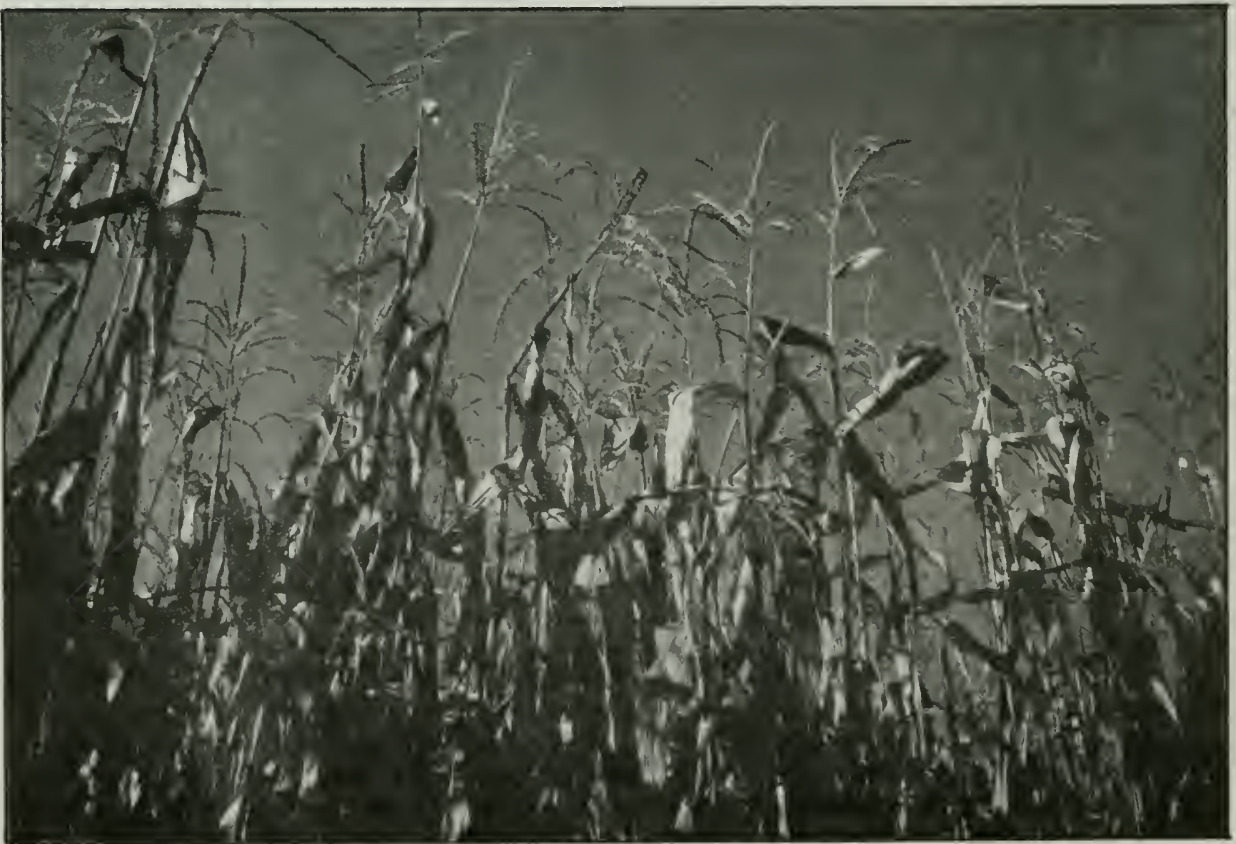

Acreages of corn to feed cattle, both as grain and as silage, are increasing significantly in California. 
CHAPTER II

LITERATURE REVIEW AND METHODOLOGY

\section{Literature Review}

The methodologies and results of agricultural projections studies for the world, the United States, and California are reviewed in this chapter to give a broad view of work done by others in this field. In preparing this material, methodologies were examined to provide ideas on the conduct of this study, and results of worldwide and U. S. projections were reviewed to provide a context for California projections, based on the growing interdependence of world trade. Results of older studies were closely surveyed to see how well the projections made for 1980 fared. Results of more recent studies will serve as a general guideline to crosscheck the results of this study.

Worldwide Crop and Livestock Projection Studies

Several analyses have recently been made of world food production and prospects for the future. The Development and Resources Corporation reviewed several recent works in this area [50]. Two general conclusions common to these were: (1) U. S. food exports generally will increase and (2) a substantial portion of this increased output will come from the addition of new cropland to production.

The Economics, Statistics, and Cooperatives Service (ESCS) of the U. S. Department of Agriculture (USDA) published 1985 projections derived from its World Grains - Oilseed - Livestock (GOL) model [99]. The GoL model is a comprehensive econometric model that solves several hundred equations in an attempt to reflect the complexity of worldwide supply and demand conditions for 12 commodities in 28 regions of the world. The model places heavy emphasis on livestock, with livestock products making up 7 of the 12 commodities. The GOL model forecasts regional and worldwide supply and demand of grain. 
The strength of such a modeling effort is that it specifies the complex worldwide conditions involved in feed-livestock interrelationships in a very detailed and sophisticated manner. However, the fact that a worldwide model must aggregate production regions and production function relationships makes it of little value in accurately analyzing livestock-feed grain parameters for California. This model is useful, however, for identifying the economic relationships involved in supply and demand of livestock and feed grains.

\section{U. S. Crop and Livestock Projections}

ESCS has also done extensive work in projecting U. S. crop and livestock production. The National Inter-Regional Agricultural projections (NIRAP) computer model was used in the early and mid-1970s to prepare a series of projections for the $U$. S. Water Resources Council [120]. These projections are primarily demandoriented; they are based on projected Gross National product and population. (Earlier projections by OBERS relied heavily on historical trends.) The more recent NIRAP projections for 1985, 1990, and 2000 are more sophisticated, simulating the farm production sector and major linkages to the natural resource base, the food consumption sector, the general economy, the farm inputs sector, and world trade [95]. The GOL model results are a major world trade component of the NIRAP model.

Other U. S. projection studies use linear programming models that have been developed at Iowa State University. Those studies analyze a variety of problems facing U. S. agriculture and project their impact on production. The studies that analyze the most relevant problems concerning california's agriculture are discussed in the following paragraphs.

Iowa State University's Center for Agricultural and Rural Development (CARD) Report 40T [53] analyzes the regional impact of increasing water costs in the western states on production in the United States. The model minimizes costs of meeting U. S. food and fiber demands, subject to production costs and land and water resource availability, by region. The objective function of cost minimization is solved for varying water prices. From these solutions, the elasticity of demand for water is estimated. Water prices are varied from 1972 levels to minimums of $\$ 15.00, \$ 22.50$, and $\$ 30.00$ per acre-foot. At higher water costs, significant amounts of irrigated acreage shift from irrigated to nonirrigated status, and some production shifts from the western states to eastern states.

Iowa State University's CARD Report 69 performs a similar analysis for energy prices, using the same basic L. P. model [54]. The model solves for a least cost solution for several high-energy price scenarios. In addition, the model also solves for a scenario that minimizes agricultural energy use. Higher energy prices (up to two times the 1974 levels) result in fewer irrigated acres. Unused cropland comes into production as a substitute for 
energy in agricultural production. toward less energy-efficient crops with higher energy prices as it is agricultural energy uses.
The shifts in production is not nearly as significant in a scenario that minimizes

One weakness of these models is that they do not reflect California's crop production technology as accurately as they might. This is because crop production techniques in the Southwest differ from those in the rest of the country. For most basic commodities, much of the production and acreage are situated east of the Rocky Mountains, and, consequently, the NIRAP and Iowa State models pay more attention to the basic crops grown in that section of the country [8] than to those grown in California.

The USDA - ESCS has combined its NIRAP projections model with the Iowa state University model in making projections for the water Resources Council (WRC) in its report, Second National Water Assessment [120]. Results in this report show that irrigation water withdrawals in California will increase about eight percent between 1975 and 2000 .

\section{U. S. Livestock Projections}

A transshipment linear programming model was used by Texas A\&M University to analyze U. S. interregional competition in the cattle feeding industry in 1971 [51]. The results indicate that California faces a major competitive disadvantage, compared to other states, in costs of feeding cattle. Feed grains and feeder cattle comprise approximately 90 percent of the total variable cost of cattle feeding, and California must import substantial quantities of both. It is important to keep in mind that this study, as well as the following studies, do not reflect changes in real energy costs occurring during the decade of the $1970 \mathrm{~s}$.

The USDA Economic Research Service used a survey of experts to project U. S. beef cattle numbers for 1980 by region. Nearly three-fourths of the growth was predicted to occur in areas other than the Pacific Coast states. California was expected to add about 79,000 beef cows between 1970 and 1980 [97].

This forecast has turned out to be somewhat high. Rather than increasing by this amount, California's beef cattle inventory numbers on January 1 had declined by 77,000 head between 1970 and 1980. Milk cow numbers, however, were underestimated. The USDA had projected that California would have $711,000 \mathrm{milk}$ cows. The number was actually 878,000 .

\section{California Crop and Livestock Studies}

A study done in 1970 by the University of California at Davis projected 1980 and 2000 California crop and livestock production [49]. The results for broad crop groups were quite reasonable, when compared to actual 1978 figures; the 1980 total acreage projection is 5 percent higher than the 1978 actual data. 
It is interesting to note that the 1980 projected field crop acreage was only 6 percent less than actual 1978 field crop acreage. Researchers took into account the fact that the increased livestock feeding would likely decline in the future.

In addition to this work, U. C. Davis made a more recent set of projections in 1977 for 1985, using a methodology similar to the earlier work. The crop projections for 2000 are lower than those made earlier, reflecting slower population growth and changes in per capita consumption [67].

As a part of its Bulletin 160 series, the Department of Water Resources makes projections of major crops, including feed and forage crops approximately every four years [30]. The latest set, completed in 1974, has acreage projections for seven differing conditions of population, per capita consumption, yield, and export. The most likely alternative chosen in 1975 projects that field crops will increase from $5.9 \mathrm{million}$ acres to about 6.3 million between 1972 and 1980. In 1979,6.7 million acres were harvested, 5 percent more than projected. Crop projections varied for specified crops within this broad crop group. In this same most likely alternative, California cattle and calf production for 1980 was projected to be 1.3 million tons (live weight). Actual 1978 data show 1.4 million tons, a close estimate [15].

A review of interregional competition studies in 1972 by U. C. Davis [41] with respect to California for poultry and livestock production led to the conclusion that California will face continued difficulties competing with other U. S. regions in cattle feeding.

Turkey and broiler production will be sensitive to production and transportation costs, while california will be likely to continue near-selfsufficiency in egg and milk production.

The main conclusions drawn from this literature review are:

(1) Demand is growing for U. S. agricultural exports of feed grains and other crops.

(2) California faces a very competitive situation with respect to livestock production in other states.

(3) The long-term projections methodology used in these studies is generally quite elementary in comparison to short-term projections methodology used in other studies [2].

(4) Regardless of the method used, the projections rely heavily on recent trends and also, either implicitly or explicitly, on judgments made by the researchers. 
Earlier long-term projections made for specific California commodities for 1980 have had a mixed degree of accuracy.

\section{Methodology}

From this literature review, three main types of methodologies used in making projections are illustrated: time series analyses, econometric models, and mathematical programming models.

Time series analysis and variants of it analyze trends in the specific parameters to be projected, subjectively taking into account causality relationships of underlying factors. Time series analyses, although widely criticized as simplistic, have some definite advantages, and they often provide a place from which to start making projections. First, changes that occur in trends do not generally occur suddenly but take time to develop. For example, the United States generally became aware of the need for energy conservation in 1974. Agricultural energy technology has changed gradually in the years since then, but crop production patterns are still reasonably similar to those of ten years ago. Nor have crop acreages in California undergone any radical change during this period [12].

In the short term, adjustments often come slowly because of fixed capital investment and because of the fact that adopted production technologies are often the ones producers are reluctant to change. Consumers also tend to change habits slowly because their tastes and preferences are often solidly established.

Another aspect of time series analysis of production location is that it implicitly captures comparative regional advantages. The occurrence of trends can be logically explained by economic variables, such as cost of production or relative prices, although these variables are not always immediately evident. The reason production of a particular crop is increasing in a given region is usually because that region has lower unit production costs than other competing regions.

Although looking at trends has these strengths, the fact that they are void of causality relationships is a serious handicap. Furthermore, while trends may be fine for short-term analyses, they can easily be far off the mark for long-term analyses. Trend extrapolation can become meaningless, once there is a random shock to the economic system large enough to change the behavior of producer or consumer. Droughts, famines, wars, and more recently, higher energy costs, have had significant impacts on the economy.

Econometric studies attempt to look at causality factors in the behavior of producer and consumer. Quantitative estimation of supply and demand curves lies at the heart of most econometric studies. Supply curves consider such variables as product prices, 
resource costs, technological advance, and input substitution and demand curves consider such variables as price, income, substitute products, and consumer tastes and preferences.

The advantages of such a method are:

(1) The model can respond to changes in costs, prices, consumer tastes, or technology that simple time series analysis does not consider.

(2) The model can be verified by prediction. This can be done by using estimated supply and demand equations to determine parameters for a recent year. The results of this calculation can then be compared with actual data obtained for the same year.

To obtain enough detail to validate them, such studies often need large quantities of data and can thus be quite costly in use of computer time. Livestock and feed grain relationships are complex, and would be expensive to analyze by econometric methods. Moreover, the results of econometric studies are often mixed.

Mathematical programming, the last methodology considered, is based on the assumption that producers are profit maximizers. Controversy is present in the literature of economics regarding the reasonableness of this assumption [48]. However, mathematical programming as a technique has the flexibility to constrain the results of profit maximization. As in econometric approaches, model results predicted by underlying technical and economic relationships can be compared to historical data for verification. With good use of economic judgment, constraints can be developed on the basis of logical assumptions that will provide results reasonably comparable to the data. Although this use of constraints can be overdone, justification often exists for some use of them to compensate for some of the misspecification of causality factors inherent in a profit-maximizing type of model. (Economics generally assumes that farmers are rational persons who at all times seek to achieve maximum profit from their operations. However, economics is often unable to consider such factors as individual preferences or other personal reasons for choosing to grow a particular crop.)

Programming models have constant costs, prices, and technological relationships. However, these can be estimated by other models, using econometric techniques or judgment. A wellconstructed model can be easily changed to reflect alterations in prices, costs, or technology. Thus, the main advantages of mathematical programming models are that they can be verified and changed easily. The disadvantages are the profit-maximizing nature of the model and the fact that price, costs, and technical relationships are fixed. 
The approach taken in this study is to combine the expertise of the researchers, the Advisory Committee, interviews with representatives of relevant interests, and economic modeling. A solid data base was developed from the first and second studies referred to in Chapter I, and the Advisory Committee and others were sought to verify the results. The assumptions made and conclusions reached were reviewed by the committee, and changes made where applicable.

After the various methodologies outlined in the first section of this chapter had been examined, it was decided that a linear mathematical programming model would be developed and used in conjunction with trend analysis and counsel from the committee. In this way a number of cross checks on the projections were provided. Although no set of projections will please everyone, it was felt that the use of several approaches and diverse expert opinion should increase the chances of achieving a reliable set of projections. 


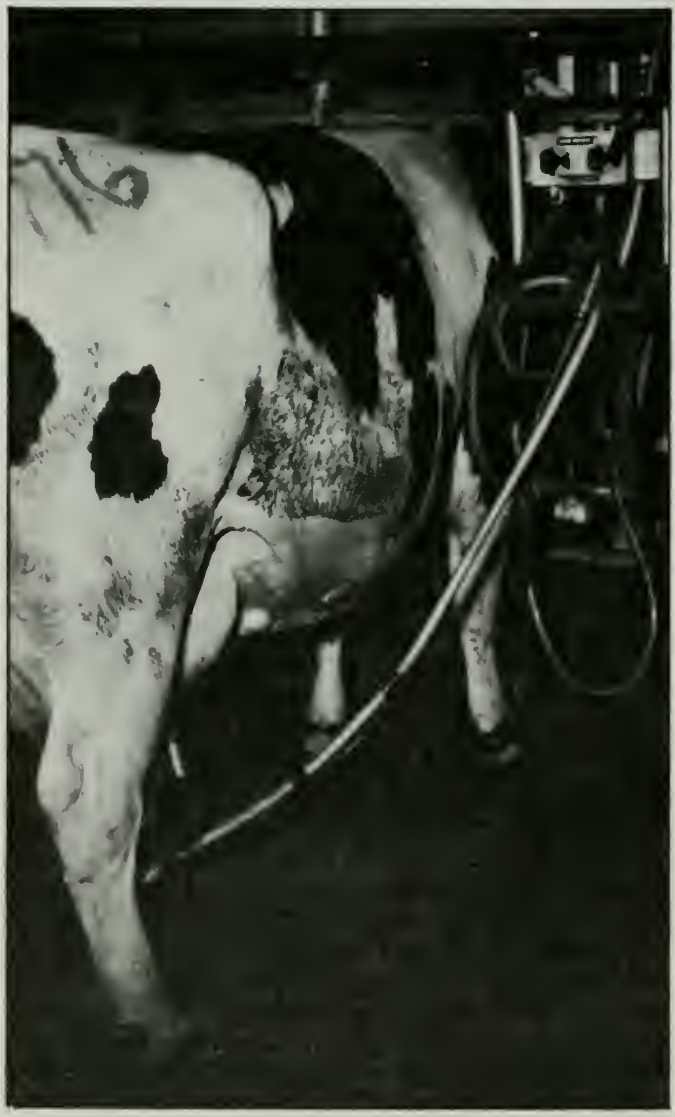

California's milk cows are, on the average, among the top milk producers in the nation. Their output has been increased greatly in recent years by genetic improvements and advances in dairy management and production methods. 


\section{CURRENT CONSUMPTION AND PRODUCTION TRENDS AND THEIR RELATIONSHIP TO CALIFORNIA'S WATER RESOURCES}

The purposes of this chapter are to provide background information for this study and to answer some basic questions. First, what are the trends in U. S. per capita consumption of livestock and poultry commodities? Second, what trends are occurring in California livestock, poultry, and feed and forage crop production? Third, where, within California, is this production taking place, and what sources of water are being used?

\section{U. S. Per Capita Consumption}

For the last 100 years, U. S. beef production and consumption have tended to follow very closely what has been commonly called the beef cattle cycle. This is a 10-14 year period in which cattle production decisions, based on the current year's prices, tend to cause over-production or under-production and, subsequently, low or high beef prices three to four years later. This is due to the physical relationships in beef production; three to four years elapse from the time a cattle producer decides to increase his/her herd until the beef from those extra cows comes on to the market. The cycle is defined by the time it takes for gestation, weaning, and fattening to be completed. As a result, beef consumption fluctuates up and down over time because of the lag time between high or low prices and production decisions made on the basis of these prices. Therefore, in comparing consumption in two different time periods, it is best to take an average value, rather than to compare any two particular years.

Figures 2 through 5 show trends in U. S. per capita consumption from 1961-1979. Beef consumption, following the cattle cycle, has increased from a 1961-65 average of 42.8 kilograms

( 95 pounds) per capita to 54.7 kilograms (121 pounds) in 1975-1979 (Figure 2). This change represents a 27 -percent increase in per capita consumption over the 19-year period. 


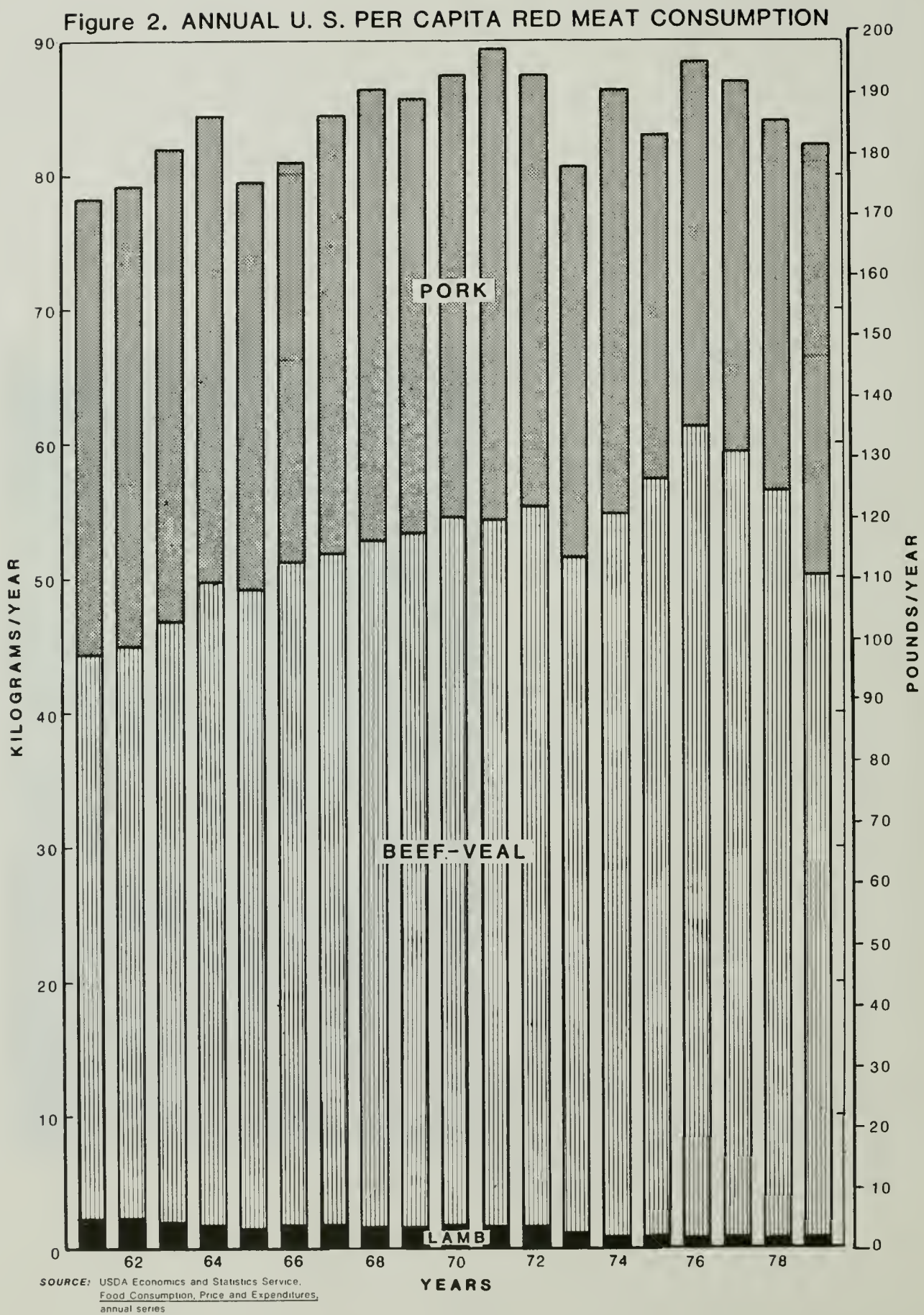


Although consumption trends for 1976-1979 are downward, such shifts have occurred at other times, although not as dramatically. Per capita beef consumption declined in 1971 and 1973; it stayed constant in 1965. Consumption in 1976 and 1977 was quite high; beef prices were relatively low during these years in relation to other alternatives [91]. Whether this recent trend downward is due mainly to the cattle cycle price effects or perhaps to changes in tastes and preferences is difficult to sort out.

Veal consumption has traditionally been very small in relation to beef consumption, representing only one to six percent of beef consumption. For that reason, veal and beef data combined show trends largely as a function of beef (Figure 2).

Pork consumption (Figure 2) has generally declined from an average of 33.4 kilograms ( 74 pounds) per capita in 1961-65 to an average of 28 kilograms (62 pounds) per capita during 1974-79. The high level for 1979,32 kilograms (70 pounds), may be largely due to the greater relative price differences between beef and pork.

Lamb consumption has never been very large in relation to beef or pork. Average levels for recent years are less than a kilogram per capita (Figure 2).

Total red meat consumption -- beef, veal, lamb and pork, (Figure 2) -- is significant because it captures some of the changes taking place among consumption of these meats. Levels have generally increased, largely reflecting changes in beef consumption, the largest component. The 1961-1965 per capita average is $81 \mathrm{kilograms}$ ( 178 pounds) and the 1975-1979 per capita average is $85 \mathrm{kilograms} \mathrm{(187} \mathrm{pounds).}$

Figure 3 shows chicken and turkey consumption increasing noticeably. Chicken consumption in particular has increased greatly, from about 14 kilograms ( 31 pounds) per capita in the early $1960 \mathrm{~s}$ to a high of around $23 \mathrm{kilograms}$ ( 51 pounds) in 1978 and 1979. Some of the chicken consumed in 1978 and 1979 represents a change from beef to poultry since chicken consumption was quite a bit lower in 1976, the peak beef consumption year. Chicken consumption in 1976 was 20 kilograms (43 pounds) per capita.

Turkey consumption has also increased since the early $1960 \mathrm{~s}$, though not as dramatically as chicken. The 1961-1965 average for turkey was $3.3 \mathrm{kilograms} \mathrm{(} 7.2$ pounds); it moved up in 1975-1979 to 4.2 kilograms ( 9 pounds). Turkey consumption is small in relation to most other meats, including chicken, its closest alternative.

The meat and poultry trends shown in Figure 4 suggest that much substitution was taking place, depending largely on relative prices. Total meat and poultry consumption declined only 2 percent from 1976-79. The peak year for beef consumption was 1976; 
Figure 3. ANNUAL U.S. PER CAPITA

TURKEY \& CHICKEN CONSUMPTION

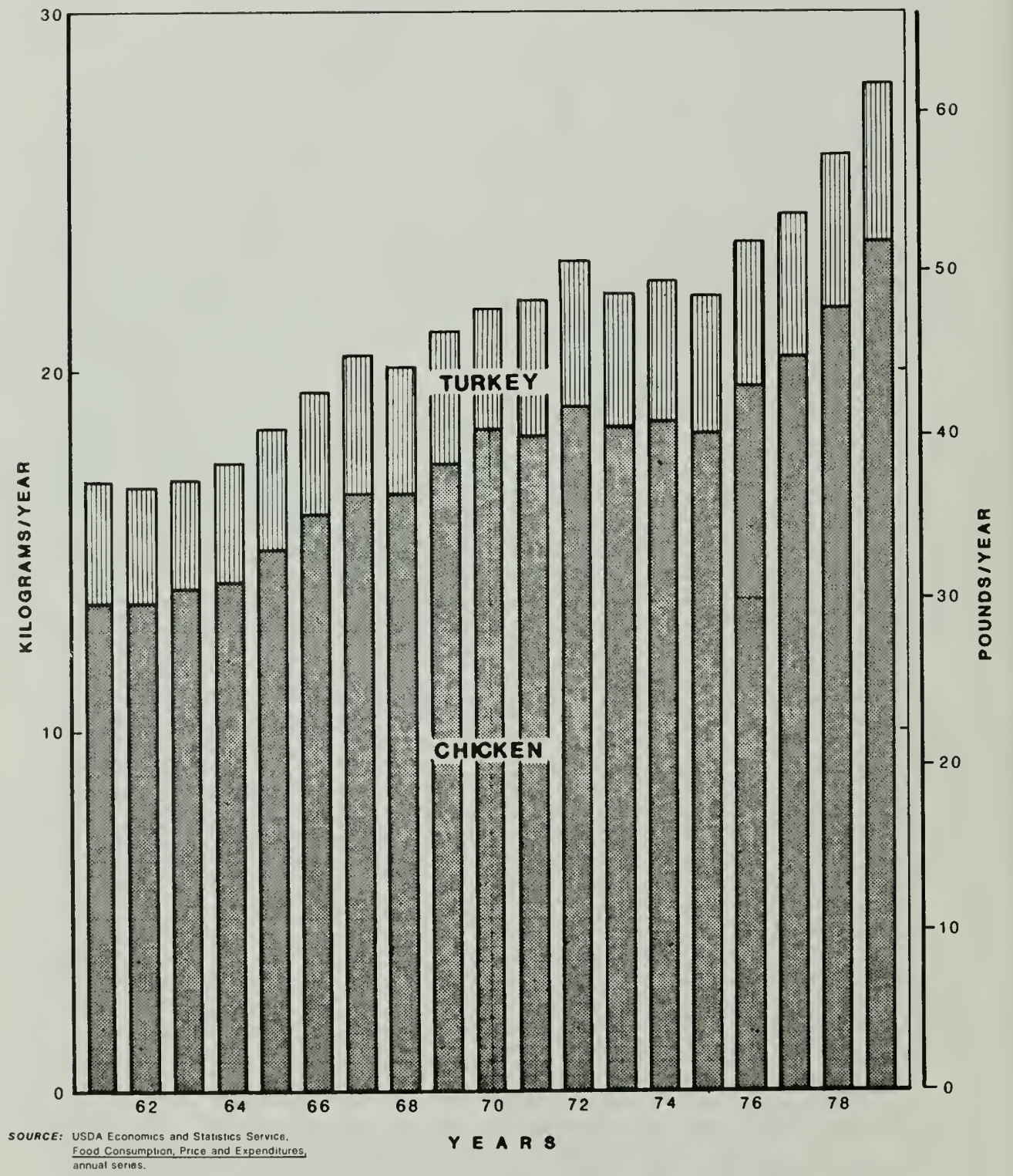


Figure 4. ANNUAL U.S. PER CAPITA MEAT AND POULTRY CONSUMPTION

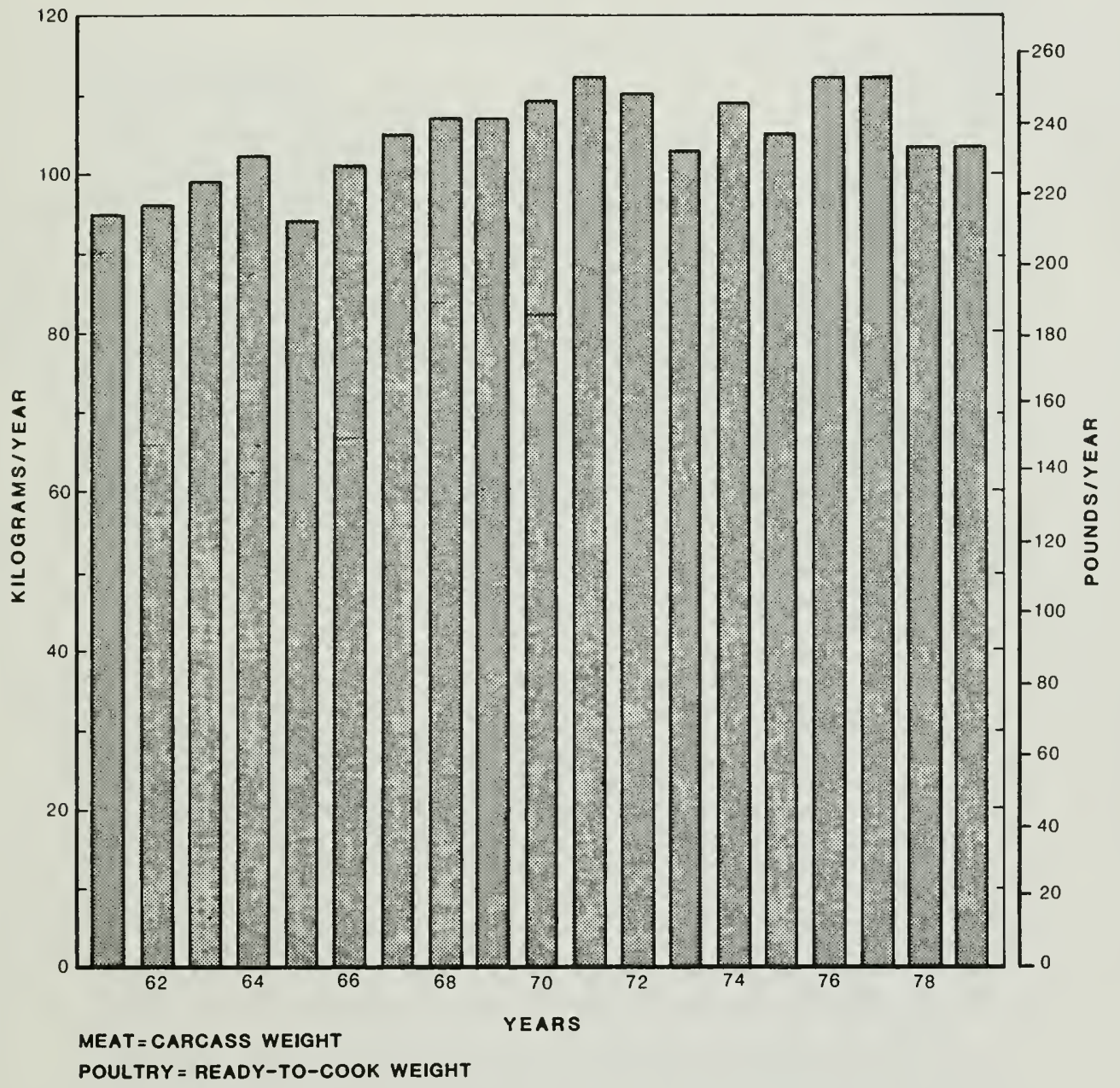

SOURCE: USDA Economics and Statistics Service. Food Consum 
it declined 16 percent during the cattle cycle downturn that occurred during this period. Average beef consumption for 1975-1979 was 12 percent higher than in 1961-1965.

U. S. per capita egg and milk consumption have both been declining generally from the levels of the 1960 s (Figure 5). The 1975-1979 level of egg consumption is 14 percent less than in 1961-1965. Milk consumption declined 13 percent during this period (on a fresh-equivalent basis). Both milk and egg consumption increased from 1978 to 1979. Whether these represent turnaround points or fluctuations in the data is difficult to say at this time.

Many of these U. S. per capita consumption figures are likely to differ markedly for California. Beef, milk, and egg consumption are likely to be higher than the U. S. average [65]. Other commodities may also show patterns different from these presented because the tastes and preferences of Californians differ somewhat from those elsewhere in this country. The per capita income is also higher than the U. S. average. The beef, milk, and egg estimates of future California per capita consumption, shown in Chapter VI, take into account these differences, using the basic methodology as outlined by the University of California Cooperative Extension Service [67].

These trends provide a rough picture of the direction in which per capita consumption has been moving in recent years. Brewster and Jacobson [7] present a longer historical perspective that traces many of these trends since 1910. The statistics compiled in this publication show trends very similar to those presented here but over a much longer period.

These trends derived from this present study are presented to provide a background with which to make per capita estimates for the future. Another perspective with a particular relationship to California consumption was presented by the Livestock Advisory Committee. Committee members generally felt that beef and poultry per capita consumption would probably increase slightly. The only opinion that countered the U. S. per capita consumption statistics are those for milk and milk product consumption, which is expected to remain constant. However, this projection seems quite reasonable in light of California's milk consumption pattern, which differs from that of the rest of the country, and the likelihood that cheese and yogurt consumption will increase to offset the declining consumption of fluid milk.

Per capita consumption projections, which take into account these past trends, other studies [98, 120], California's unique consumption statistics, and the committee's opinions, are discussed in more detail in Chapter $V$. 
Figure 5. ANNUAL U.S. PER CAPITA MILK AND EGG CONSUMPTION
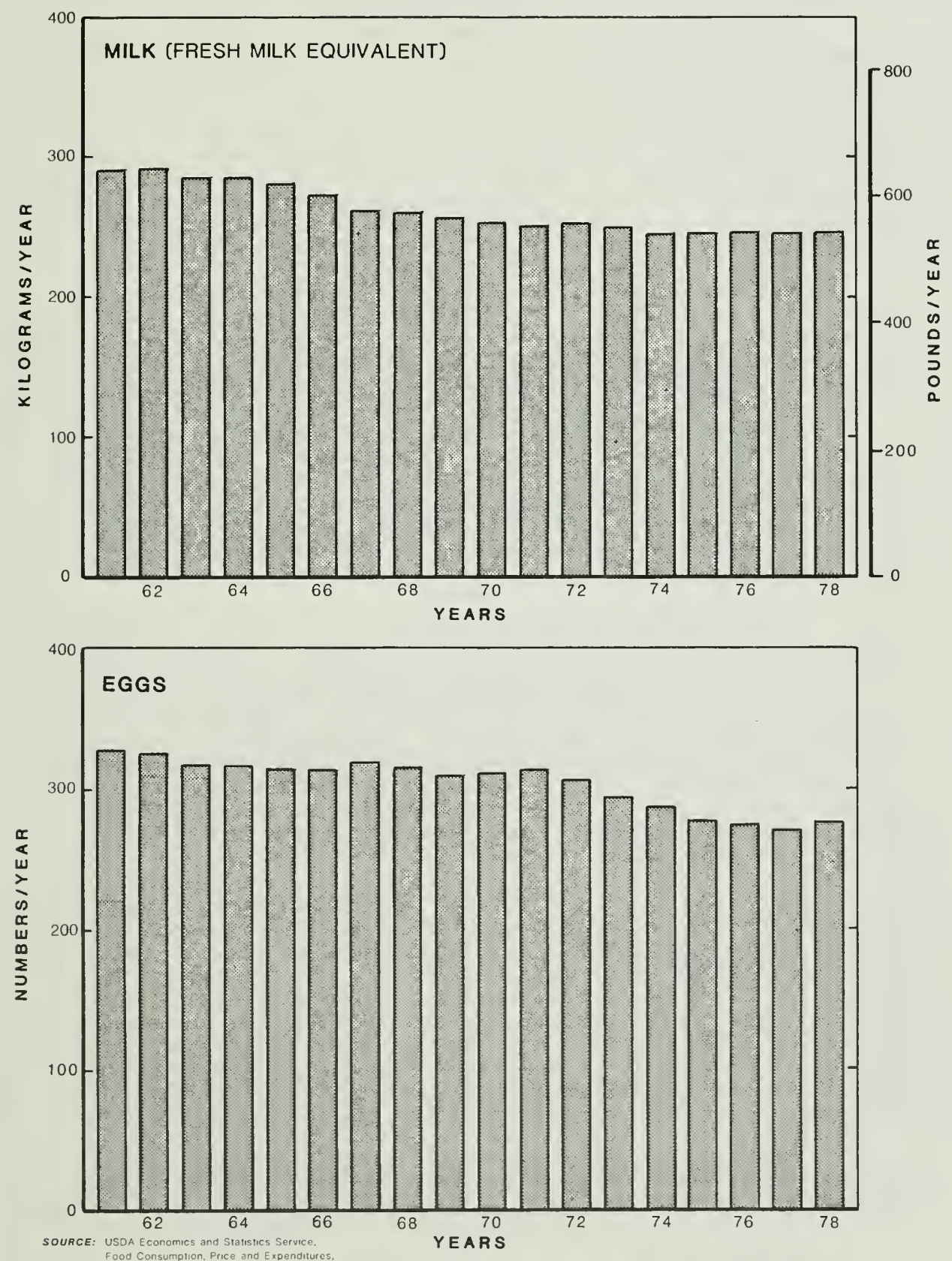
Figures 6 through 23 show trends in California animal numbers, commodity production, and feed and forage crop acreage for 1961-1978. A mathematical description is also shown of the statistically significant linear trend lines. These are fitted by means of ordinary least squares, where the dependent variable is a function of time. Extrapolations from trends shown in these graphs are presented in numerical form in Chapter VIII. These extrapolations are not our final projections. However, they do quantify the directions in which trends are headed, and serve to help evaluate projections made later in this report.

The coefficients of determination $\left(R^{2}\right)$ are given for most of the trend lines. They indicate how well the trend lines fit the data. The standard error of the estimate, given in parentheses under the intercept and coefficient values, indicates the degree of variability of the constant and the slope coefficients.

Numbers of California milk cows declined in the 1960s, but increased in the 1970s. Because of this shift, the trend line fitted is not statistically significant; the average number of milk cows is pictured instead (Figure 6). Total California milk production (Figure 7 ) shows a strong positive slope, the $\mathrm{R}^{2}=.92$. Milk production per cow is also quite well-fitted over time (Figure 8 ).

There are two distinct sectors in the beef industry: the feeder cattle and the feedlot cattle sectors. Feeder cattle on range or pasture land are raised principally on grass until they are large enough to enter feedlots, where they are then fed principally on grain. These two beef industry sectors are showing opposite trends: beef cow numbers (representative of feeder cattle) are increasing, and feedlot marketings are decreasing (Figures 9 and 10 ). In neither case is the trend particularly strong, the $\mathrm{R}^{2}$ being .36 for the beef cow trend and .21 for the feedlot marketings trend. The cyclical nature of the cattle industry is particularly evident for beef cow numbers.

California broiler chicken production shows a strong positive statistical trend, with an $\mathrm{R}^{2}$ of .95 (Figure 11). Egg production is also positively sloped, but the statistical fit is much poorer at an $\mathrm{R}^{2}$ of .32 (Figure 12). In the $1970 \mathrm{~s}$, egg production leveled off considerably, no doubt reflecting the declining per capita egg consumption discussed in the previous section of this chapter. Average egg layer numbers increased generally, especially in the 1960 s (Figure 13). Turkeys raised in California show an extremely weak upward trend, with an $\mathrm{R}^{2}$ of only .02, indicating wide fluctuation (Figure 14).

The crop acreage trends also show quite variable relationships. Alfalfa hay shows a declining acreage over the recent 18-year period that was examined, but the relationship is a weak 
Figure 6. AVERAGE ANNUAL CALIFORNIA MILK COW NUMBERS (1961-1978)

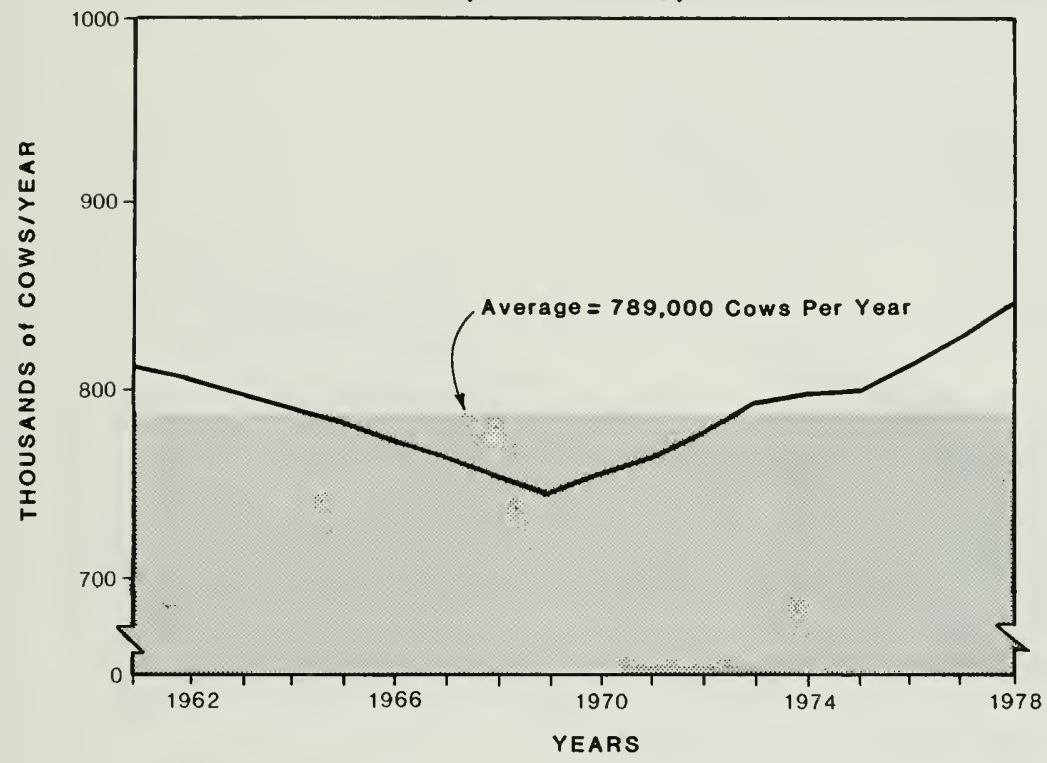

Figure 7. CALIFORNIA MILK PRODUCTION

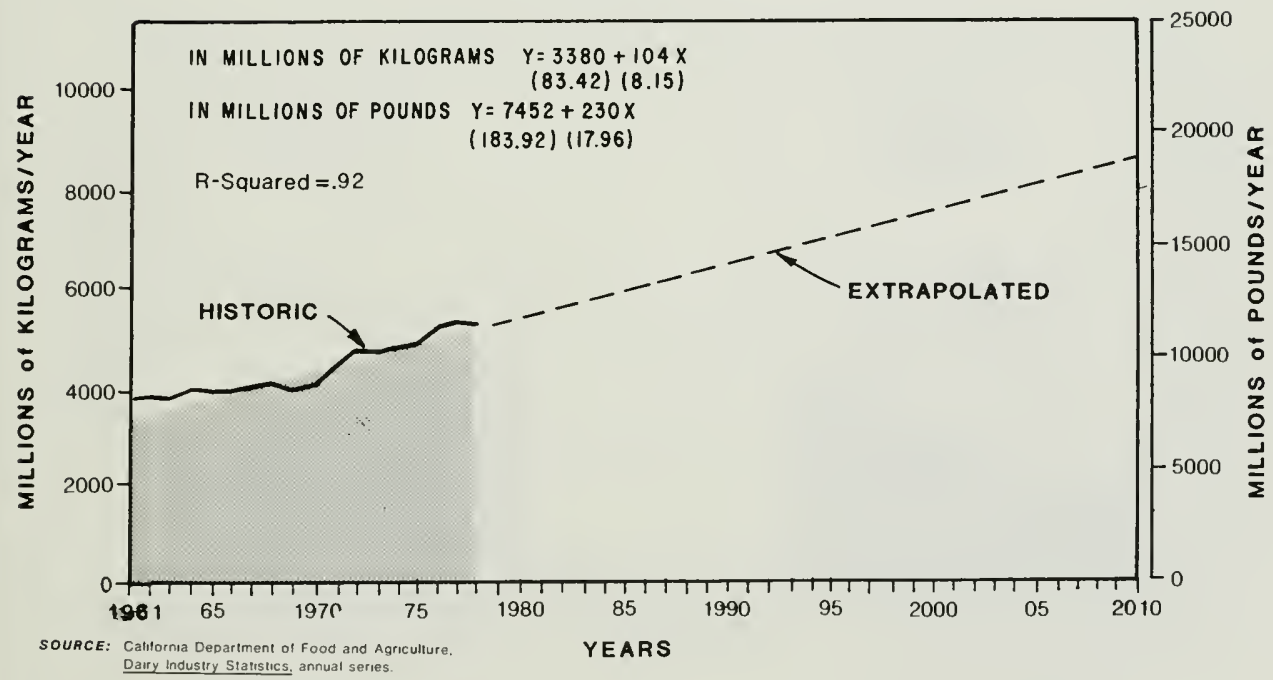


Figure 8. CALIFORNIA MILK PRODUCTION PER COW

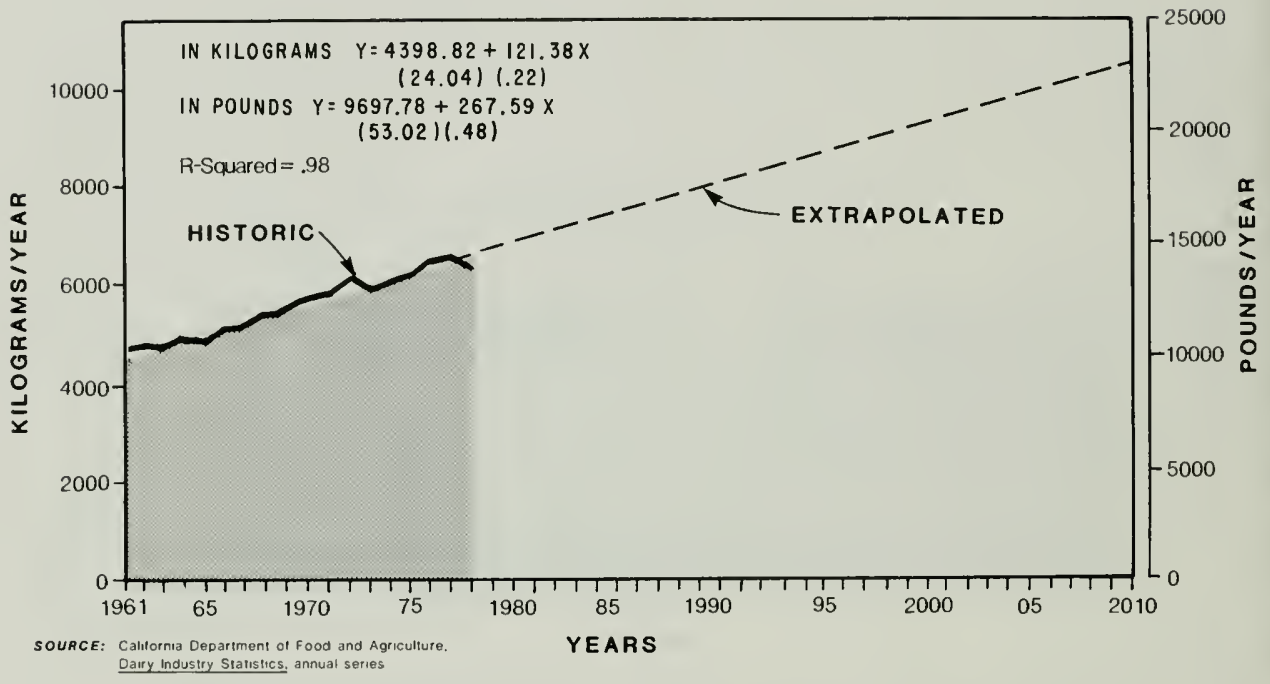

Figure 9. CALIFORNIA BEEF COW NUMBERS JANUARY 1

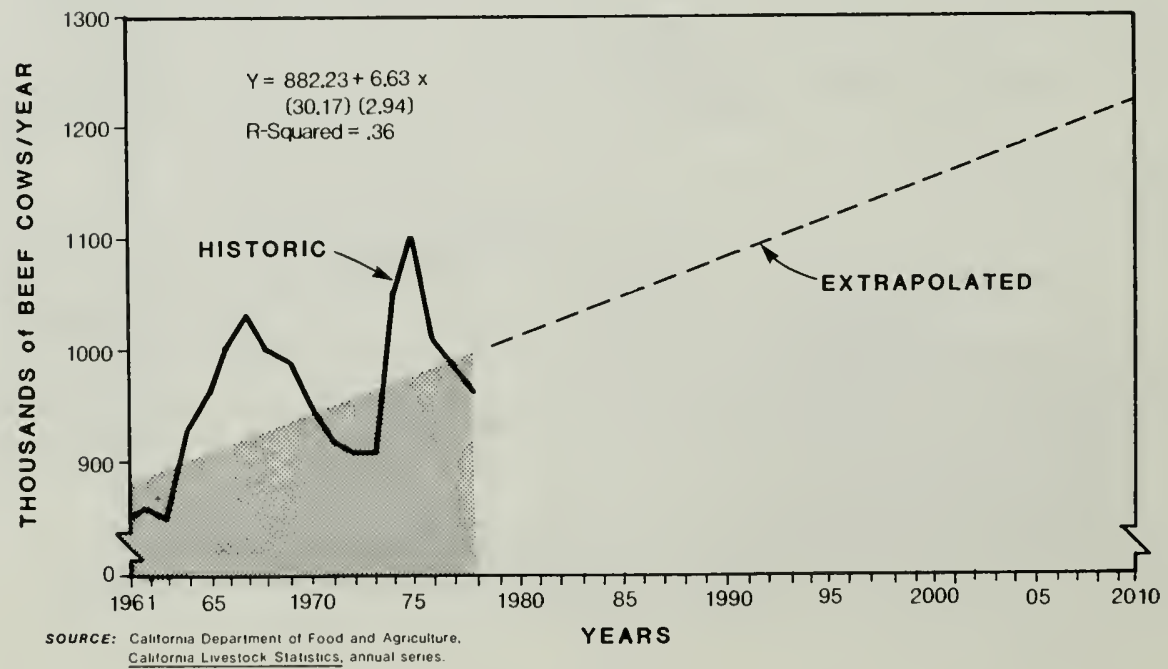


Figure 10. ANNUAL CALIFORNIA FEEDLOT MARKETINGS

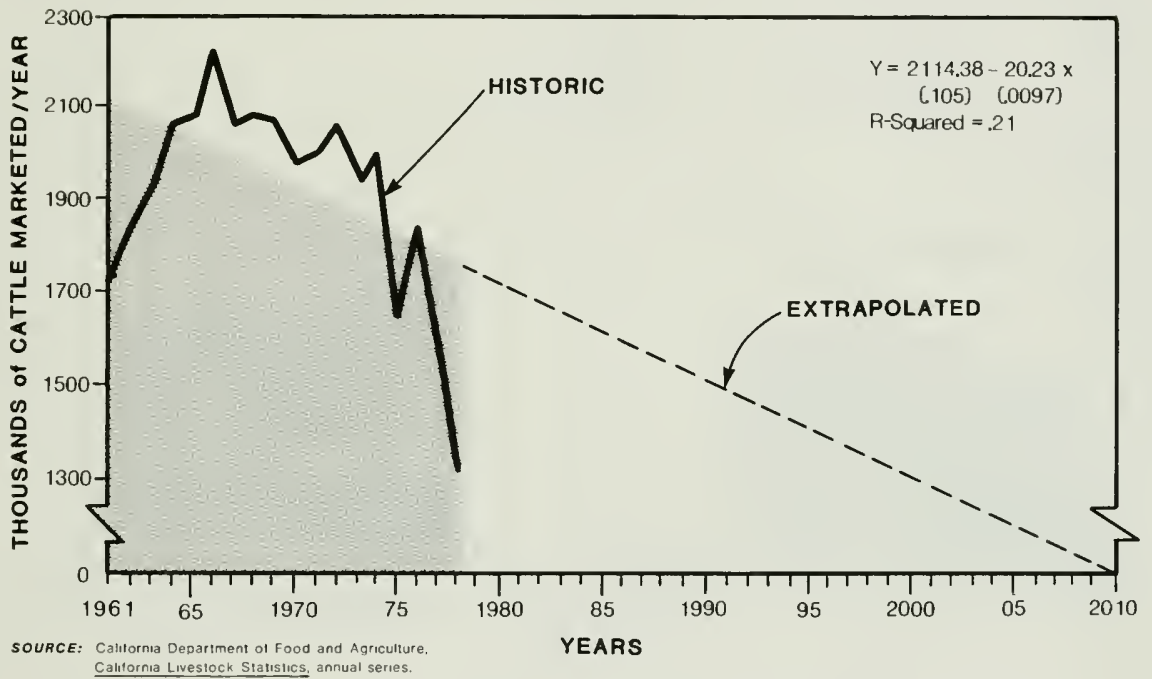

Figure 11. ANNUAL NUMBER OF CALIFORNIA BROILERS \& FRYERS PRODUCED

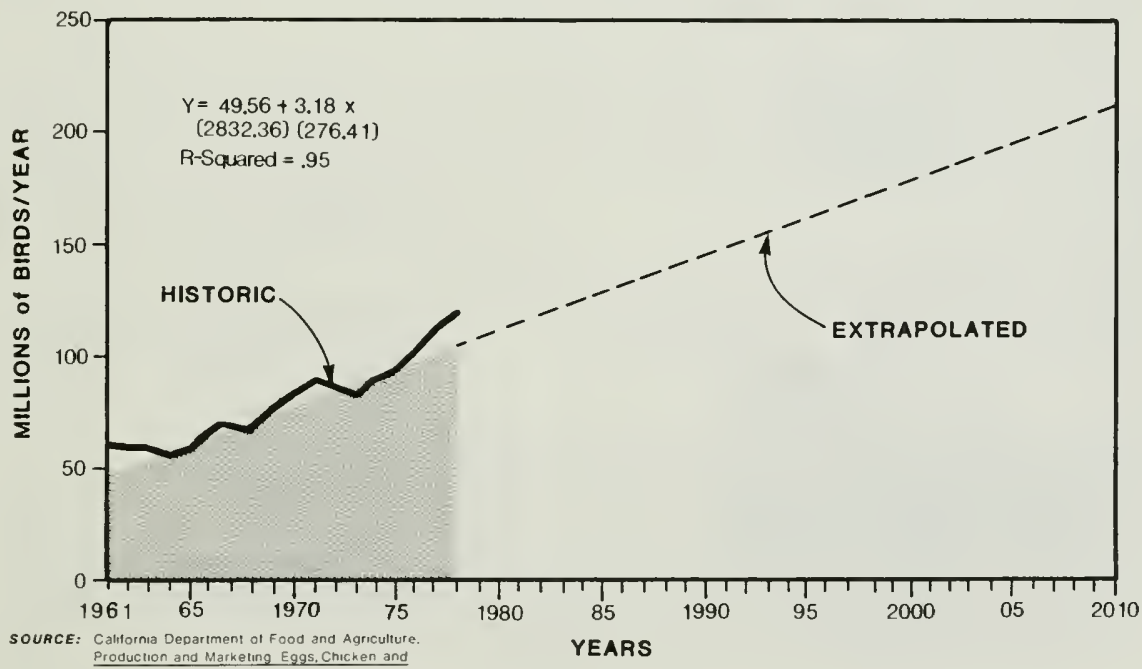


Figure 12. ANNUAL CALIFORNIA EGG PRODUCTION

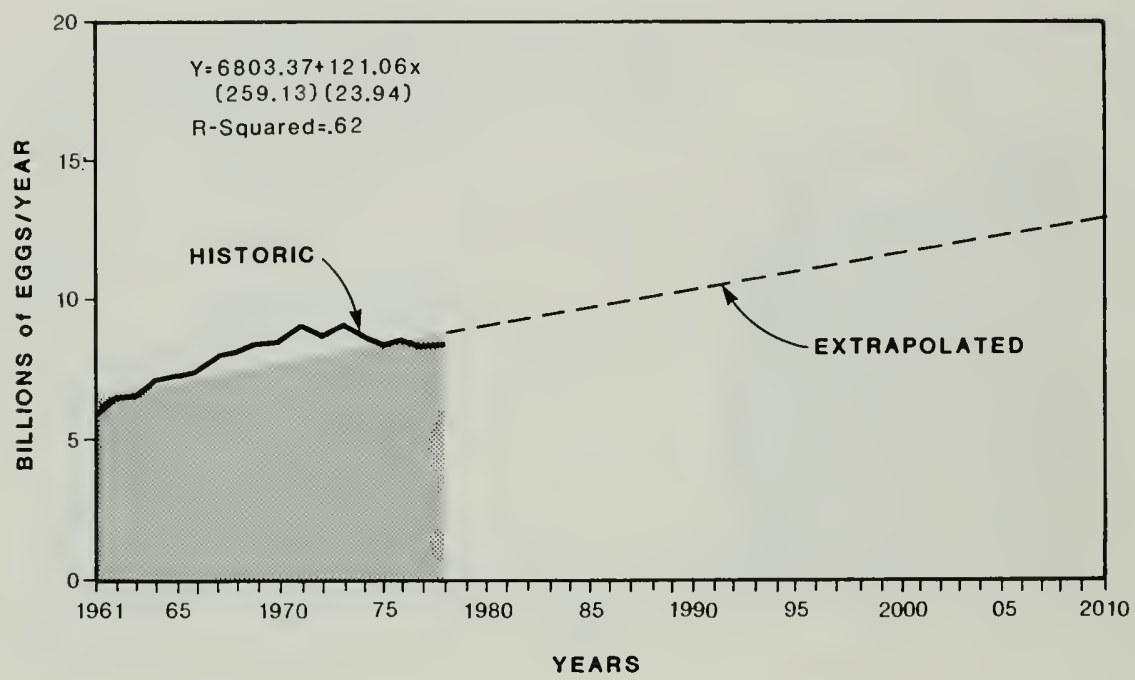

Figure 13, AVERAGE NUMBER OF CALIFORNIA EGG LAYERS

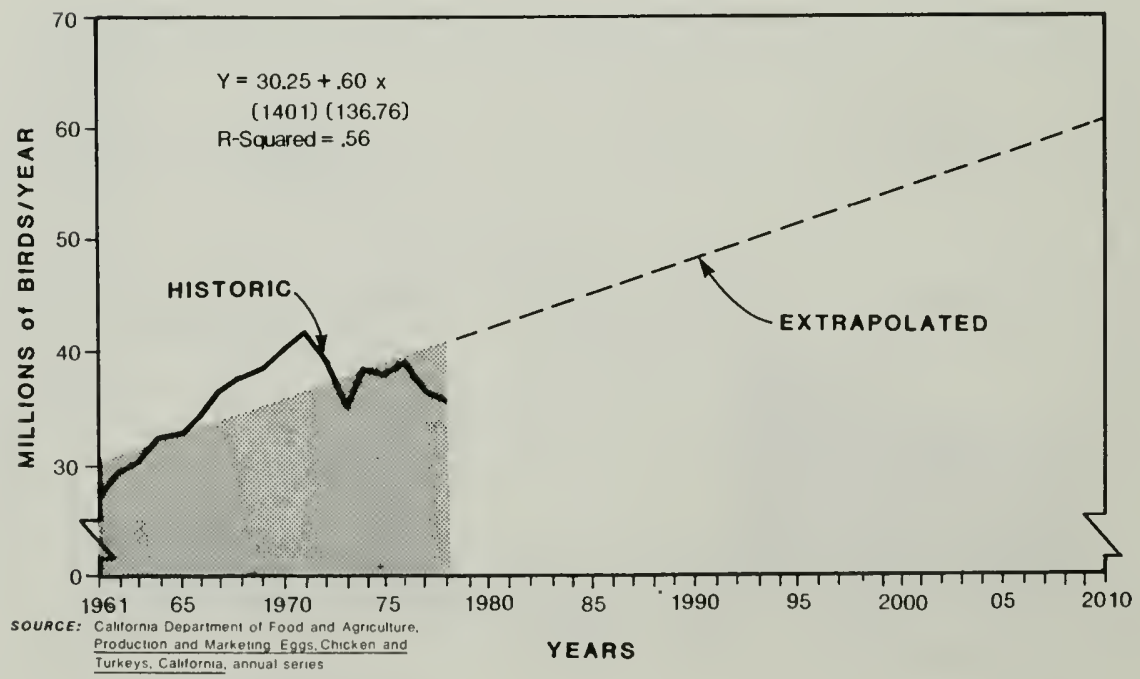


Figure 14. CALIFORNIA TURKEYS RAISED

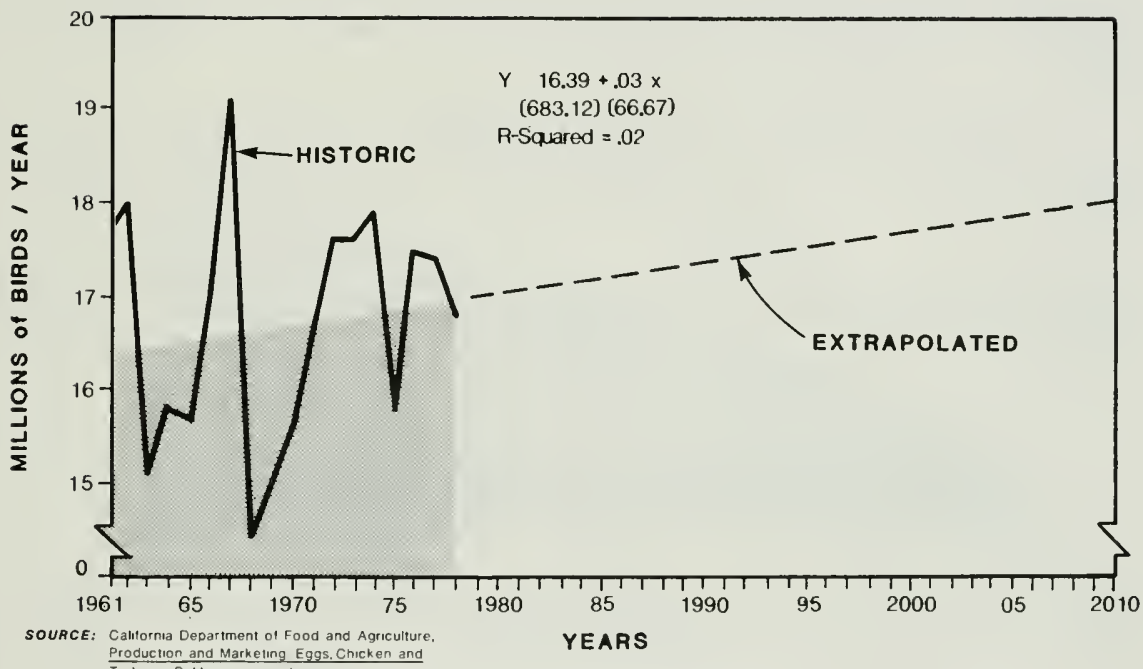

Production and Markeling Eggs. Chicken and

Turkeys, Callornia, annual series.

one (Figure 15). Other types of hay show a stronger downward trend (Figure 16), with a very sharp drop occurring in the late $1960 \mathrm{~s}$. Since then, other hay acreage has remained nearly constant at around 200 thousand hectares (500 thousand acres).

Barley acreage is also declining, and the fitted trend shows a much stronger relationship than that of hay (Figure 17). From levels of 550-602 hectares $(1,200-1,300$ thousand acres) in the early 1960s, production declined in the late 1970s to levels of around 350-400 thousand hectares (900-950 thousand acres). The $\mathrm{R}^{2}$ is a fairly respectable .83 .

Like barley, California sorghum production is showing a generally declining trend. However, the relationship is an extremely weak one (Figure 18). Oat acreage shows a similar pattern (Figure 19).

In contrast to barley, sorghum, and oats acreage, corn (for grain and silage) and wheat acreage are increasing significantly, and their coefficients of determination are fairly high, $.86, .91$ and .75 respectively (Eigures 20-22). Corn for grain has increased from 32-40 thousand hectares (80-100 thousand acres) to 101 to 120 thousand hectares (250-300 thousand acres) in recent years. Corn for silage acreage has roughly doubled during this 
period, and wheat acreage has generally more than doubled. Significantly, feed crop acreage as a group has remained fairly constant (Figure 23).

About 50 percent of the wheat and barley in the state is irrigated, according to the 1974 U. S. Census of Agriculture [123] estimates. Wheat tends to use more water per acre than barley, however.

Corn acreage, nearly all of which is irrigated, is increasing significantly in recent years, implying an increase in total water use for annual feed crops (all other things being equal).

A trend line was not fitted to statewide irrigated pasture acreage because the statewide data are not tabulated in published reports.

Figure 15. CALIFORNIA ALFALFA HAY ACREAGE

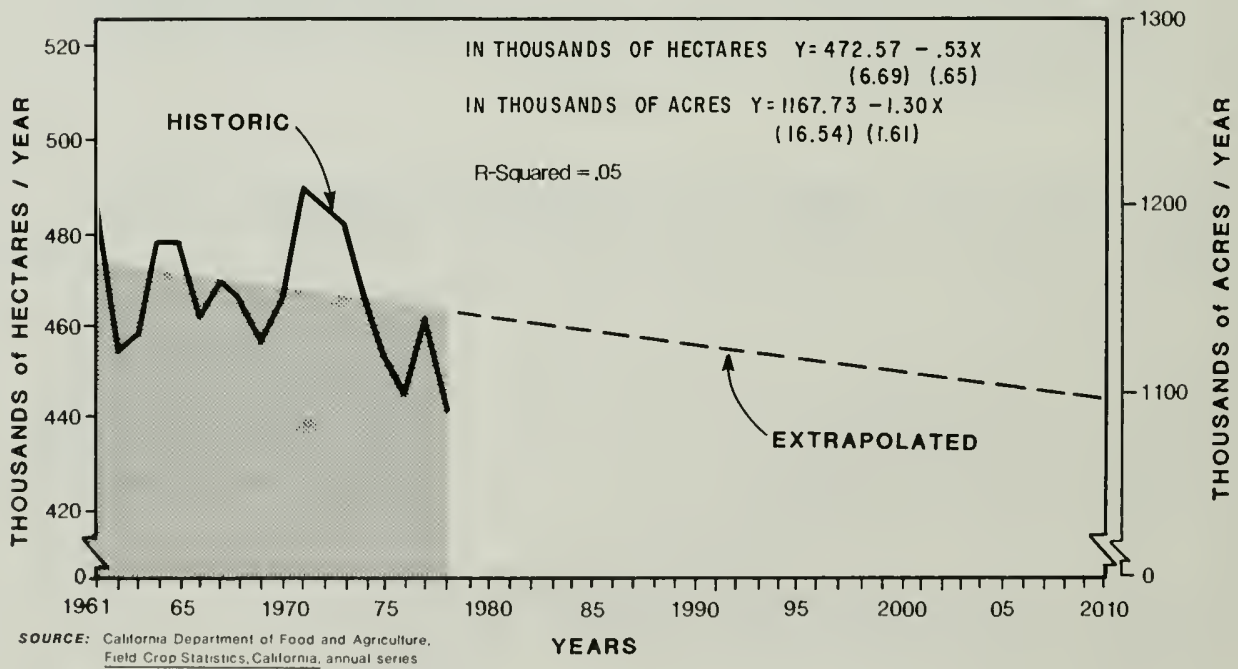


Figure 16. CALIFORNIA HAY (OTHER THAN ALFALFA) ACREAGE (1961-1978)

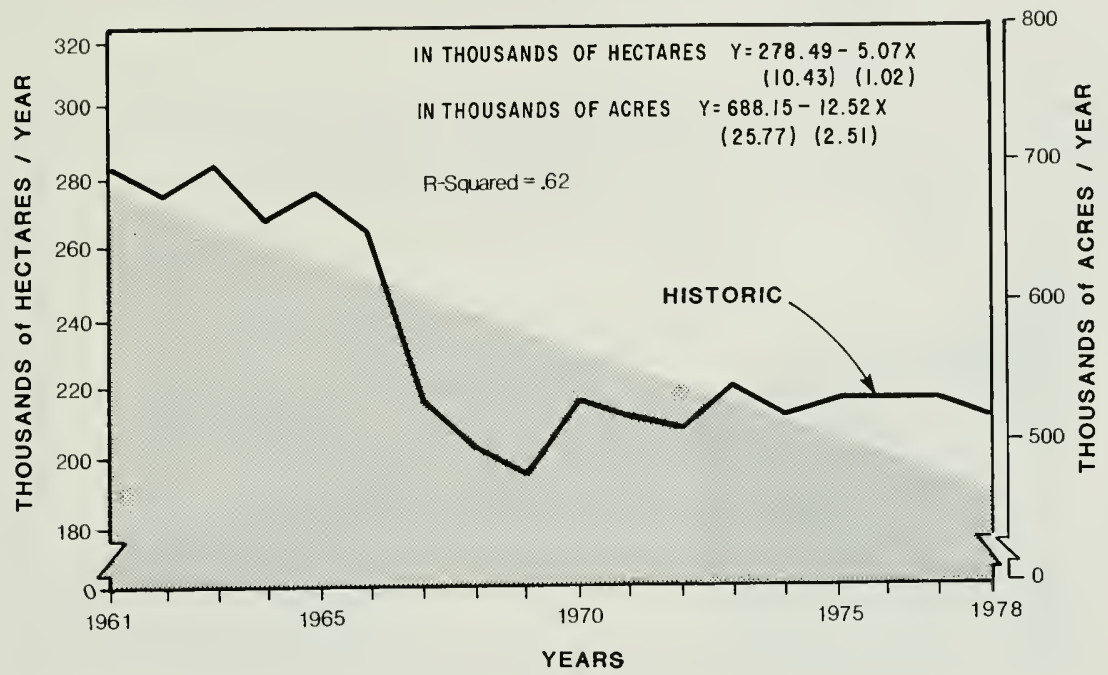

Figure 17. CALIFORNIA BARLEY ACREAGE (1961-1978)

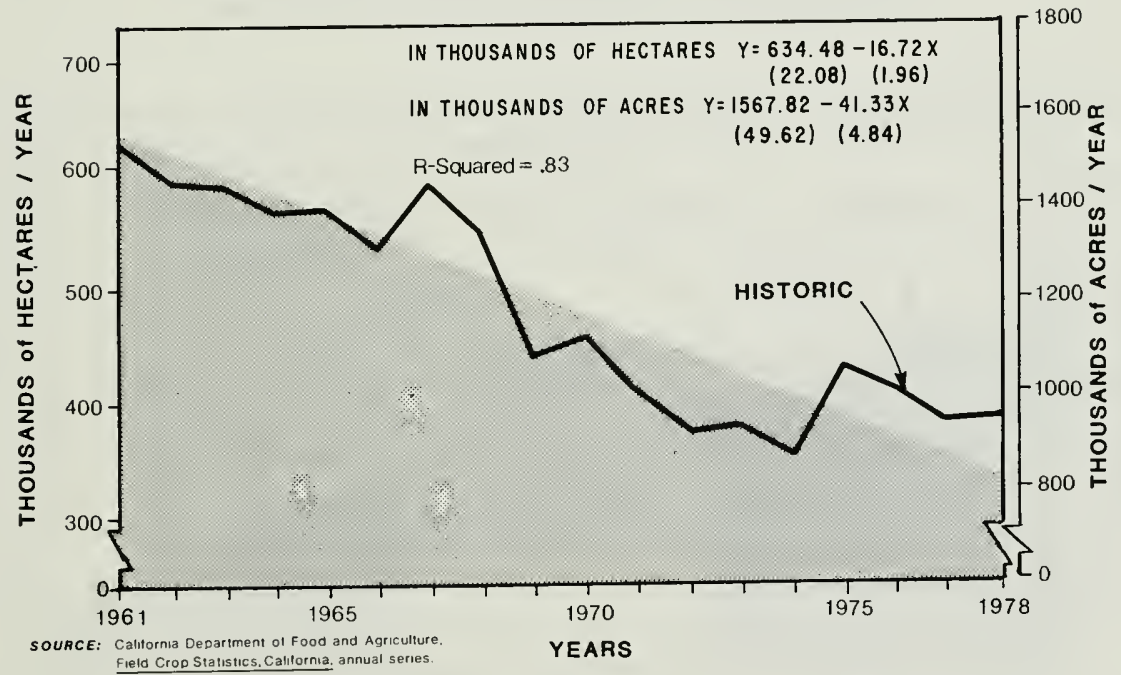


Figure 18. CALIFORNIA SORGHUM ACREAGE

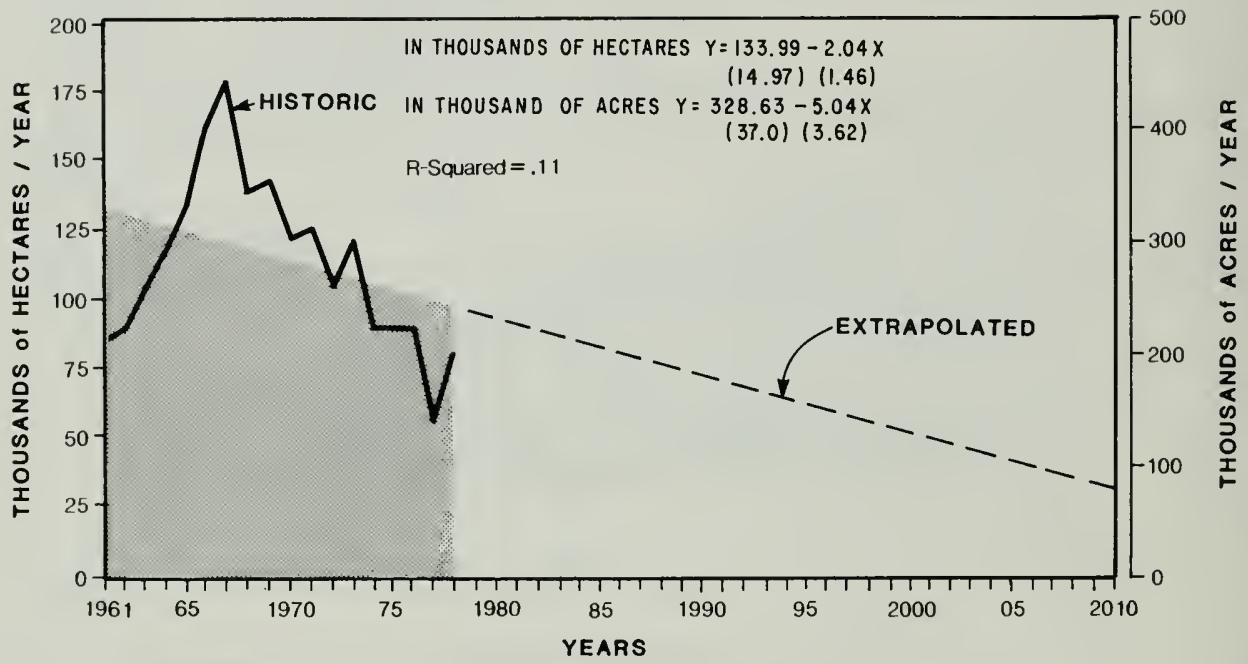

Figure 19. CALIFORNIA OATS ACREAGE

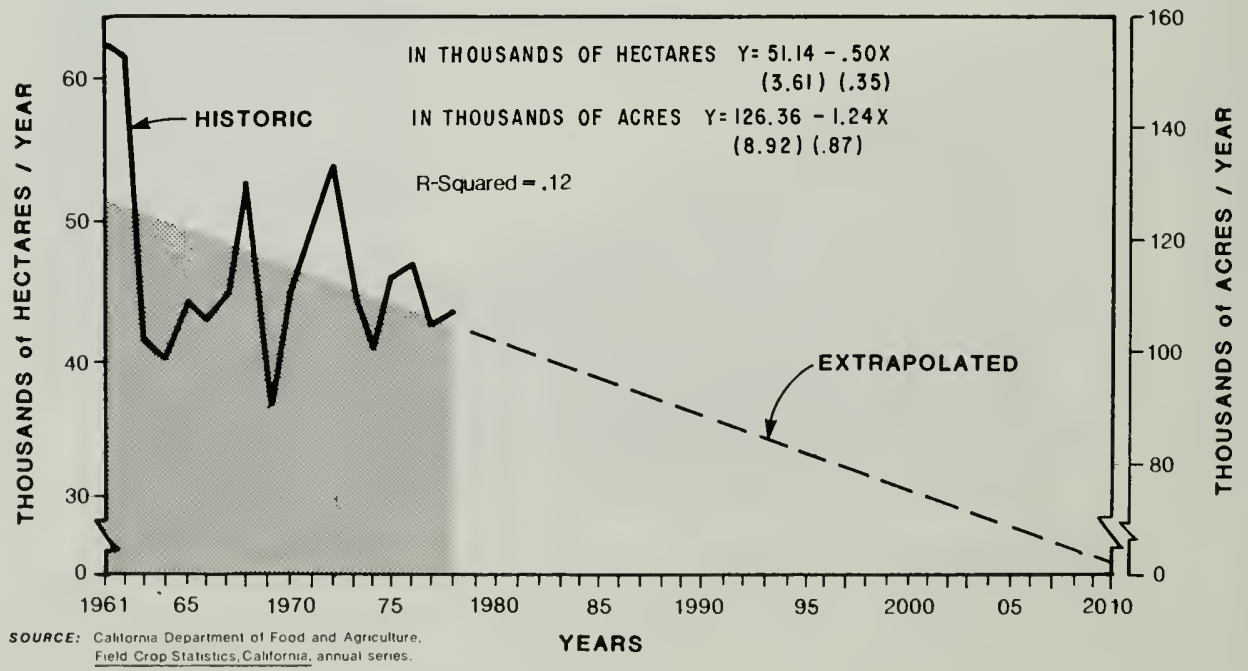


Figure 20. CALIFORNIA CORN SILAGE

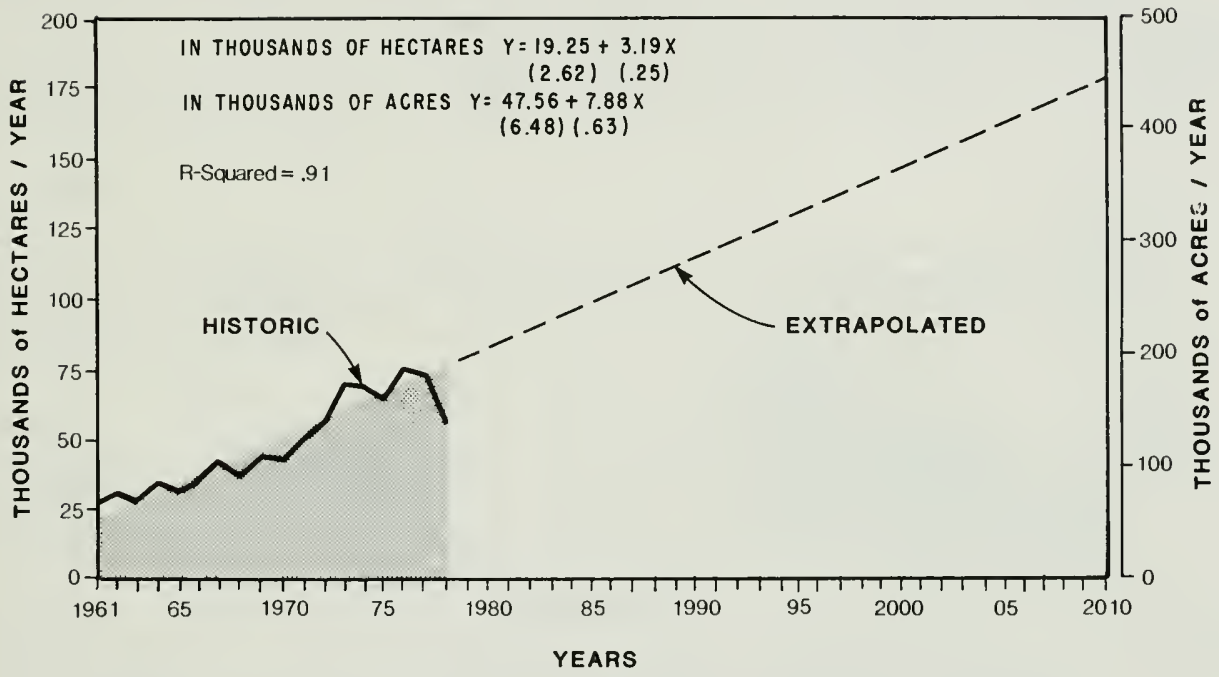

Figure 21. CALIFORNIA CORN GRAIN ACREAGE

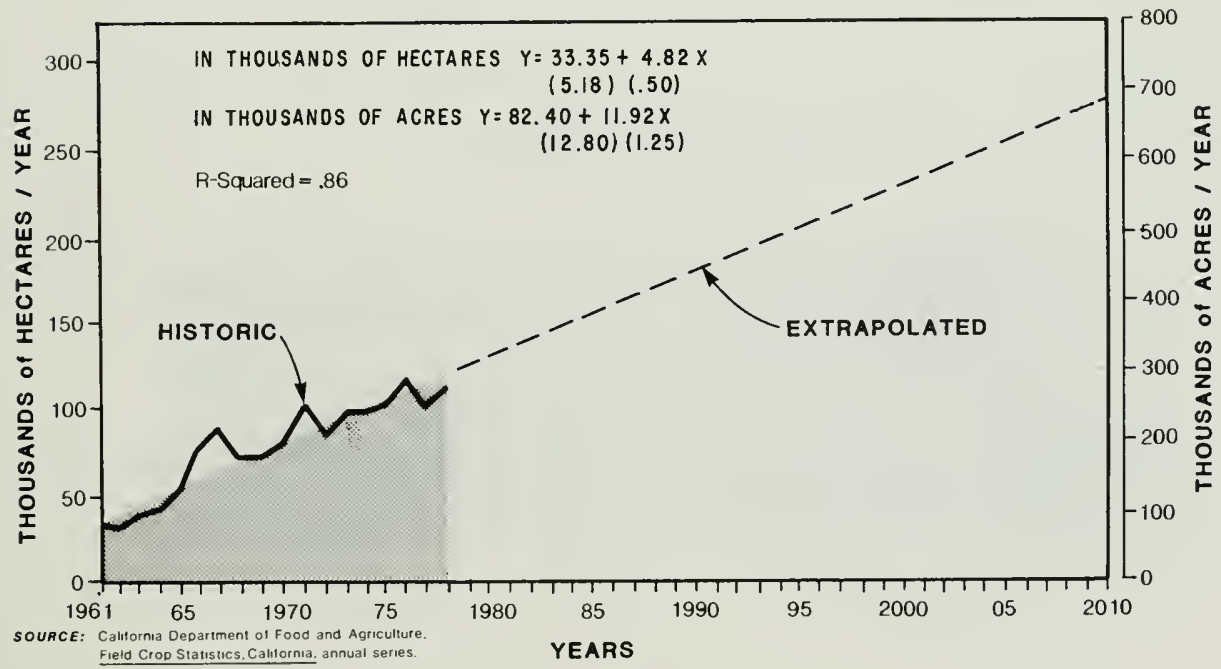


Figure 22. CALIFORNIA WHEAT ACREAGE

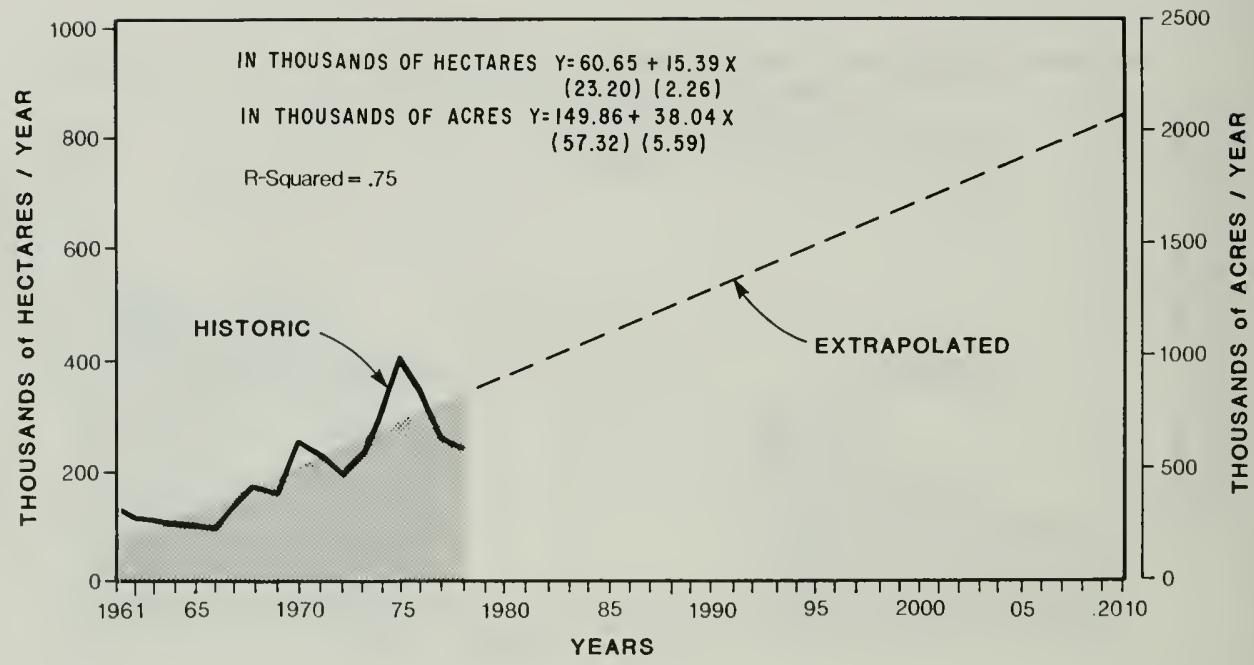

Figure 23. ANNUAL FEED CROP ACREAGE (1961-1978)

(BARLEY, CORN, OATS, SORGHUM, and WHEAT)

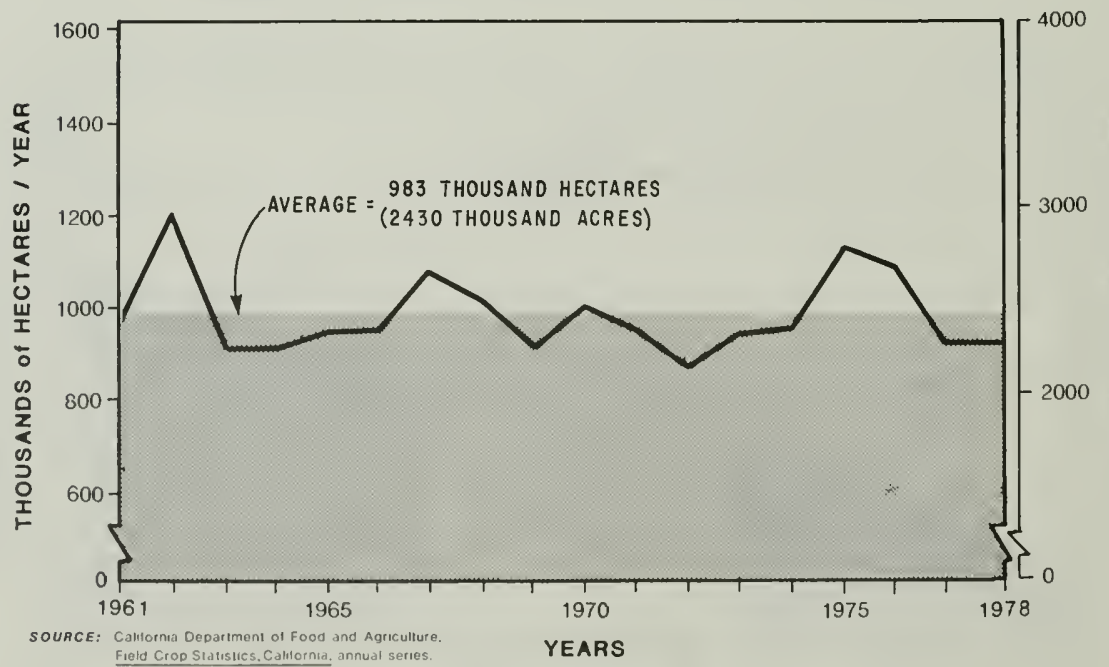


Knowing where feed and forage crops are currently grown in California is an important consideration in making a reliable set of projections. Knowledge of regional production is important because of regional variation in water costs and availability, soils and climate, proximity to markets, and opportunities to grow alternative crops. Therefore, data tabulated from reports of each county's Agricultural Commissioner were used to obtain a picture of feed and forage crop acreage by region.

\section{Regions}

The regions chosen for examination are shown in Figure 24 . They were selected principally to meet the requirements of the linear programming model described in Chapter $V$. The regions are delineated by county boundaries to facilitate data collection.

Region 1, Southern Tulare Lake, made up roughly of the southern portion of the Tulare Lake Hydrologic Basin, primarily is an area of high-cost water where significant quantities of ground water from deep wells and state water Project (SWP) water are used.

Region 2, Northern Tulare Lake, the valley's northern portion, typically has lower water costs than does Region 1. Region 3, San Joaquin-Sacramento River, represents the rest of the San Joaquin Valley, plus the Sacramento Valley, and Region 4 is the Imperial Valley. Region 5, Southern Coastal and Desert, covers the large Southern California consuming region. Scattered areas of agriculture exist in the Central Coast area and Southern California. Region 6, Northern California Bay and Mountain, covers the San Francisco Bay consuming region and northern mountain area agriculture.

\section{Acreage Percentages By Region}

Table 1 shows the percentages of specified feed and forage crops grown in each of these regions and typical water costs. These costs are not statistical averages but are derived from typical water costs by region developed at the University of California [58]. They provide at least an approximation of relative regional water costs in California. (Costs within a given region often vary considerably from these typical costs.)

Alfalfa is grown throughout the state under extremely variable conditions. It is also grown in locations at some distance from point of consumption and must therefore be shipped to centers of dairy activity (Table 1). Moreover, the commodity often fits diverse crop rotations. It may also be a region's best crop to grow in relation to other crops suitable for that region. 


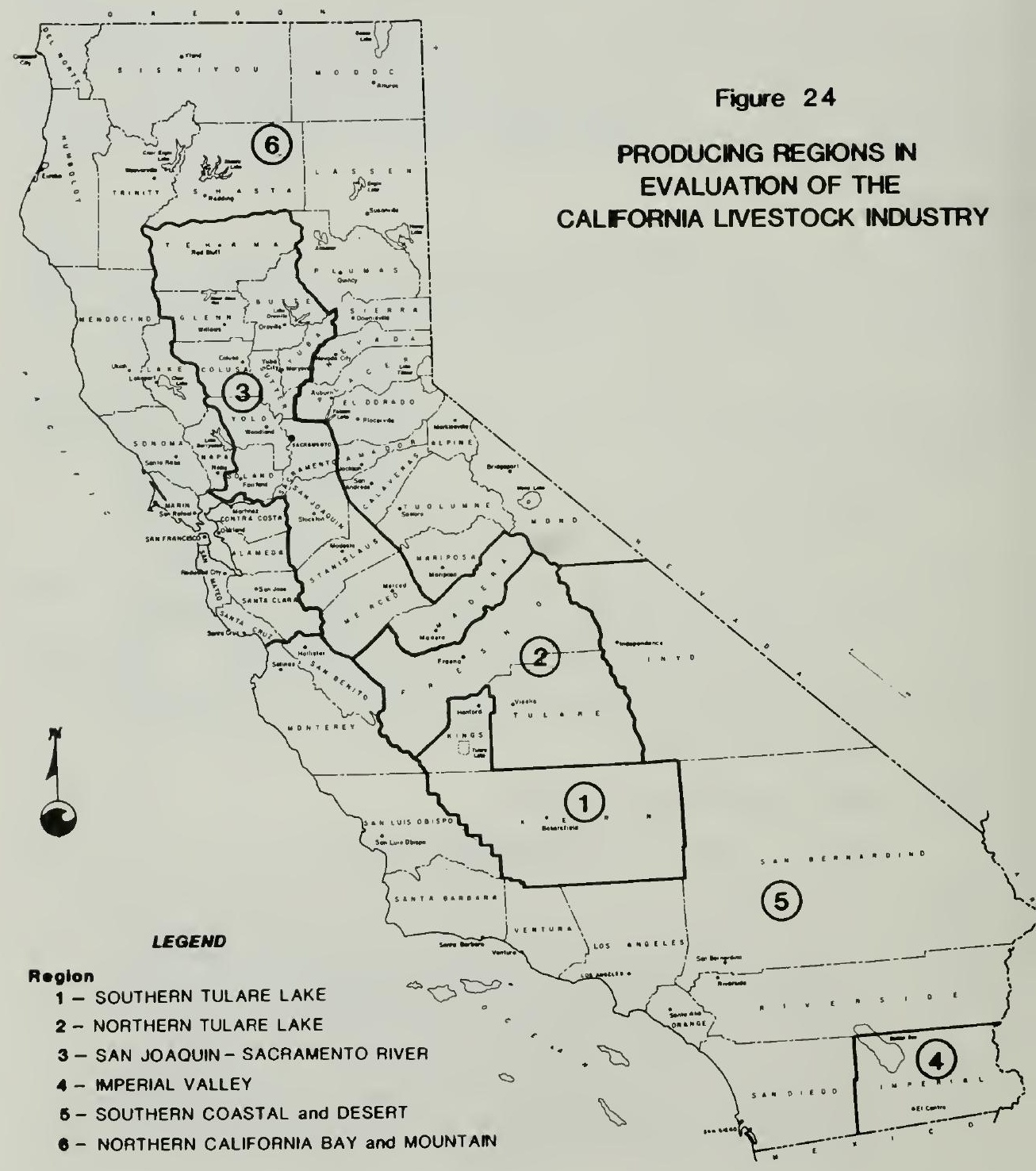




\begin{tabular}{|c|c|c|c|c|c|c|c|c|c|c|c|c|}
\hline & Regions & $\begin{array}{c}\text { Alfalfa } \\
\text { Hay }\end{array}$ & $\begin{array}{c}\text { Grain } \\
\text { Hay }\end{array}$ & $\begin{array}{c}\text { Othet } \\
\text { Hay }\end{array}$ & $\begin{array}{c}\text { Irrigated } \\
\text { Pasture }\end{array}$ & Barley & $\begin{array}{l}\text { Corn } \\
\text { (Crain) }\end{array}$ & $\begin{array}{c}\text { Corn } \\
\text { (Silage) }\end{array}$ & Oats & Sorghum & Wheat & $\begin{array}{l}\text { Typical } 1978 \\
\text { Water Cost, in } \\
\text { dollars per } \\
\text { cubic dekametres } \\
\text { (acre-feet) }\end{array}$ \\
\hline 1 & Southern Tulate Lake & 13 & 3 & 0 & 2 & 21 & 3 & 11 & 5 & 23 & 8 & $\begin{array}{c}19 \\
(23)\end{array}$ \\
\hline 2 & Northern Tulate Lake & 16 & 3 & 4 & 5 & 29 & 7 & 23 & 1 & 13 & 5 & $\begin{array}{l}10 \\
(12)\end{array}$ \\
\hline 3 & San Joaquin - Sacramento River & 25 & 30 & 20 & 48 & 28 & 88 & 60 & 54 & 50 & 49 & $\stackrel{6}{(7)}$ \\
\hline 4 & Imperial Valley & 19 & 0 & 0 & 0 & 1 & 0 & 0 & 0 & 11 & 22 & $\begin{array}{l}5 \\
(6)\end{array}$ \\
\hline 5 & Southern Coastal and Desert & 12 & 36 & 3 & 5 & 15 & 0 & 3 & 17 & 2 & 12 & $\begin{array}{l}11 \\
(13)\end{array}$ \\
\hline 6 & $\begin{array}{l}\text { Northern California Bay } \\
\text { and Mountain }\end{array}$ & 15 & 28 & 73 & 40 & 6 & 2 & 3 & 23 & 1 & 4 & $\begin{array}{l}7 \\
(9)\end{array}$ \\
\hline \multicolumn{2}{|c|}{ California } & 100 & 100 & 100 & 100 & 100 & 100 & 100 & 100 & 100 & 100 & \\
\hline
\end{tabular}

Source: [11].

The occurrence of other types of hay-producing lands is more concentrated, either in Northern California (Regions 3 and 6) or near the large riding horse population of Region 5 (grain hay). Irrigated pasture is concentrated in Northern California; 87 percent is located in Regions 3 and 6 .

More than three-fourths of the main feed grains (corn for grain, sorghum, and barley) are produced in the central valley in Regions 1, 2, and 3. These areas grow 87 percent of California's barley, 98 percent of corn for grain, 93 percent of corn for silage, 60 percent of oats, 86 percent of sorghum, and 62 percent of wheat. Eighty-eight percent of the corn for grain and nearly half the oats, sorghum, and wheat are grown in the San JoaquinSacramento River Region (Region 3 ).

Feed grain crops tend to fit in well with existing crop rotations and existing soil and water conditions in these areas. In addition, continuing upward trends in the international demand for all cereals have made growing these crops more profitable in relation to other crop options.

Acreage and water Sources by Region

Most of the water used to irrigate feed and forage crops is not newly-developed water (Table 2). Ninety-six percent of irrigated pasture uses either ground water or locally-developed surface water. No significant amount is supported by water from the state water Project. 
PERCENTAGES OF SELECTED FEED AND FORAGE CROP ACREAGE GROWN IN CALIFORNIA IN 1975, BY WATER SOURCE

\begin{tabular}{|c|c|c|c|c|c|}
\hline Crop & $\begin{array}{l}\text { SwP a/ } \\
\text { water }\end{array}$ & $\begin{array}{l}\text { USBR }- \text { / } \\
\text { Water }\end{array}$ & $\begin{array}{c}\text { Other } \\
\text { Surface }\end{array}$ & $\begin{array}{l}\text { Ground } \\
\text { Water }\end{array}$ & Total \\
\hline Irrigated Pasture & 0 & 4 & 41 & 55 & 100 \\
\hline Alfalfa Hay & 1 & 25 & 20 & 54 & 100 \\
\hline Feed Grains c/ & 10 & 36 & 20 & 34 & 100 \\
\hline \multicolumn{6}{|c|}{ 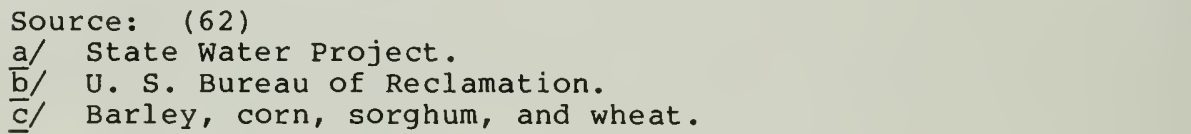 } \\
\hline
\end{tabular}

Given the extent of major producing regions of irrigated pasture and the typical water costs by region (Table 1) [62], 87 percent of pasture is grown with water costing less than $\$ 7.00$ a cubic dekametre $(\$ 9.00$ an acre-foot). This table also shows that these are among the lowest water costs in the state. Newly developed water in all regions is likely to be more costly than existing supplies because the lowest-cost supplies have already been tapped. Therefore, based on current irrigated pasture production patterns, it seems unlikely that much pasture will be grown with new water supplies. Little current pasture production uses water supplied by either the federal or state water projects.

Alfalfa, another high water-using crop, is also often produced with water that is relatively inexpensive. Table 2 shows that only 1 percent of alfalfa grown uses swP water. The major supply of water ( 54 percent) is ground water. The U. S. Bureau of Reclamation (USBR) supplies 25 percent of the water for alfalfa and only 4 percent for irrigated pasture. About 60 percent of the alfalfa hay grown uses water costing less than $\$ 7.00$ a cubic dekametre $(\$ 9.00$ an acre-foot) (Table 1$)$.

Major irrigated feed grains (barley, corn, sorghum, and wheat) are grown with water from a wider variety of sources than are alfalfa or pasture [62]. The sources that supply the greatest amount for feed grains are ground water and water from the federal Central Valley project - each nearly 35 percent of the total. Nearly 90 percent of corn for grain and 60 percent of corn for 
silage are grown in the San Joaquin-Sacramento River Region (Region 3), an area in which water typically costs less than in other regions (Table 1). Fifty percent of the sorghum grown in California is also grown in this region. Statewide average applied water-use coefficients for corn and sorghum of 9.8 and 7.6 cubic dekametres per hectare are generally higher than those for barley and oats, the other major feed grains. Barley and oats both have average applied coefficients of 4.3 cubic dekametres per hectare. (The comparison of statewide average applied water-use coefficients in English units of measurement is corn, 3.2 acrefeet per acre; sorghum, 2.5 acre-feet per acre; and barley and oats, each 1.4 acre-feet per acre.) Wheat has a higher water-use coefficient than barley in some areas, but less than 10 percent of wheat grown in California is used for animal feeding.

Estimated Water Use by Feed and Forage crops

Table 3 shows estimated water use and percentages of each for various groups of feed and forage crops for 1976-78. A three-year average was chosen to avoid yearly fluctuations in crop plantings. About $17.1 \mathrm{million}$ cubic dekametres (13.8 million acre-feet) of water are used to produce all feed and forage crops. This is slightly less than half ( 45 percent) the Department of Water Resources' 1972 estimate of 39.1 million cubic dekametres (31.7 million acre-feet) of estimated total irrigation water applied in 1972. Allowing for the fact that total applied water may have increased between 1972 and 1978 , it seems reasonable to estimate that somewhat less than 45 percent of the irrigation water presently applied is used for feed and forage crops.

Crops in Table 3 are categorized in three major groups: feed grains, hay, and pasture. Feed grains as a group use less total water than either alfalfa hay or pasture. This is partly because they use less water per acre than alfalfa hay or pasture, many acres of barley and wheat are dry farmed. Feed grains use 28 percent of water applied to feed crops and used for animal feeding. The remaining 72 percent of water use associated with animal feeding is divided between hay (40 percent) and irrigated pasture (32 percent).

\section{Crop Water Use Embodied in Feeding Livestock and Poultry}

A key concept to keep in mind for the purpose of this study is the analysis of the amount of applied water livestock and poultry consume indirectly through consumption of feed and forage crops. Water consumed directly by poultry and livestock for watering and cleaning is insignificant in relation to such indirect use [33]. 


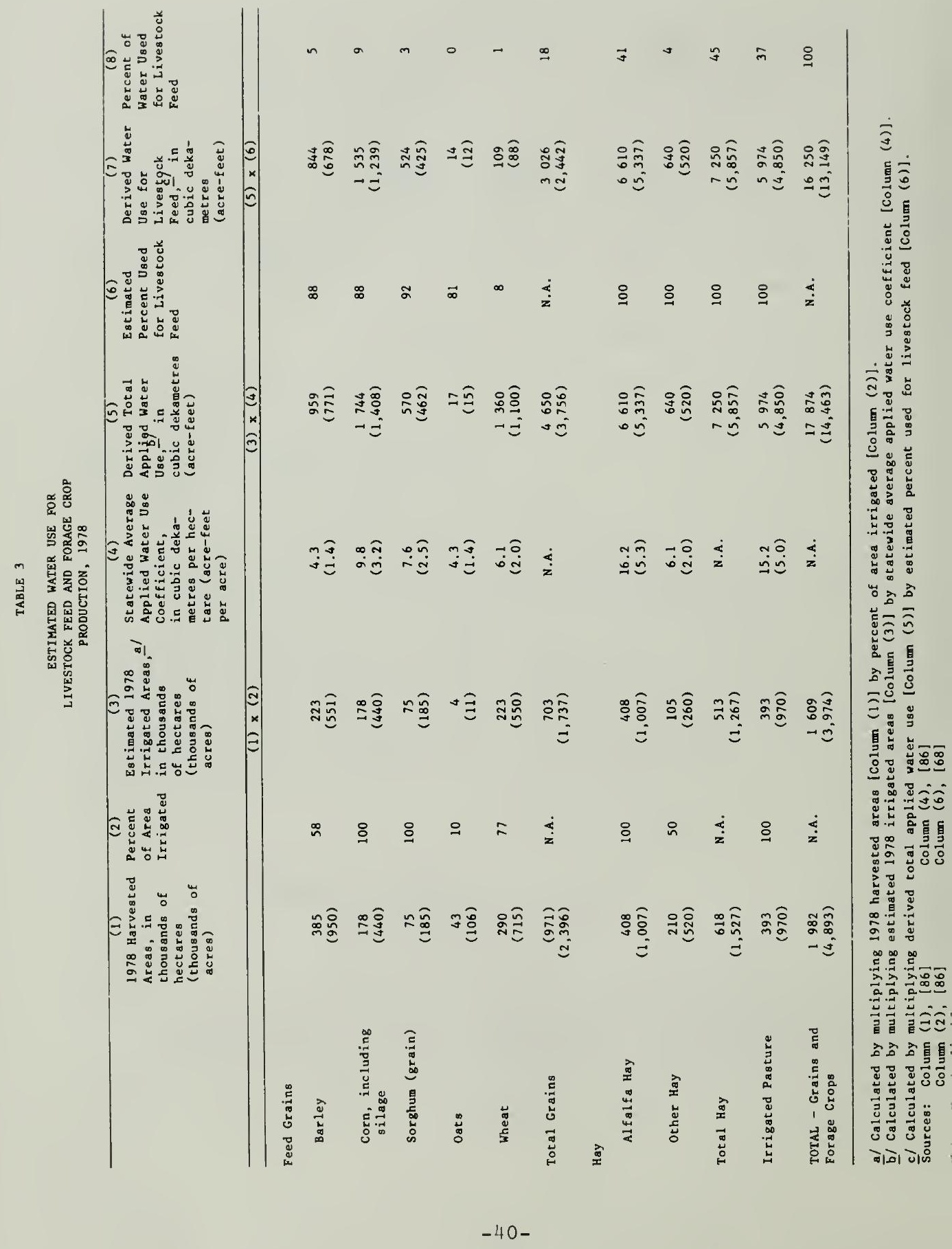


To better explain indirect water consumption by livestock and poultry, it is necessary to briefly describe the types of feed and forage consumed and the animals associated with these types of feed or forage use and water consumption. Animals consume four main types of feed and forage: range, pasture, hay, and feed concentrates. Each of these has varying applied water use coefficients and is used by different animals as major consumers.

Rangeland receives no irrigation water and, consequently, tends to be very seasonal in its use, depending on the land elevation, water conditions in the area, and surrounding habitat, among other factors. Pasture, on the other hand, is a high water-using crop in California (Table 3). Both pasture and range can provide forage for livestock, but pasture tends to be much more productive, with an average statewide annual yield of 25.7 animal unit months (AUM) per hectare (10.4 AUM per acre). The production average for rangeland has been estimated to be 1.0 AUM per hectare (.39 AUM per acre).

Both alfalfa hay and other types of hay are produced in California. Alfalfa represents the largest in both acreage and production (Table 3). Nearly all alfalfa is irrigated, while only about half of other types of hay require water (Table 3). Alfalfa hay also has a much higher average statewide applied water use coefficient -- 16.2 cubic dekametres per hectare ( 5.3 acre-feet per acre), compared with 6.1 cubic dekametres per hectare ( 2 acrefeet per acre) for other types of hay.

All hay and pasture are generally consumed by livestock; little, if any, production is used for human or industrial purposes.

Beef cattle and sheep are the primary consumers of rangeland forage. California produced $26.5 \mathrm{million}$ AUM per year in the three-year period from 1974 to 1976. Of this total, rangeland grazing provided about $14.0 \mathrm{million}$ AUM per year. Irrigated pasture provided the remainder, $12.5 \mathrm{million}$ AUM per year. Roughly one half the weight gain of California beef cattle is derived from rangeland, which uses no significant quantities of water [68]. The grazing requirement for the rest is provided by irrigated pasture. Often pasture is used seasonally in combination with rangeland because rangeland cannot support many cattle during dry summer months.

Dairy cows are the major consumers of irrigated pasture, but exactly what percentage of the total they consume is unknown. Dairy cows also consume an estimated three-fourths of all alfalfa hay produced in California [68]. Given the estimate stated earlier in this report that 72 percent of applied water use associated with livestock is used for hay and pasture production, significant quantities of water are indirectly consumed by the dairy industry and smaller amounts are indirectly consumed by the beef industry. 
Both dairy and beef cattle also consume large quantities of feed concentrates. Feed concentrates consist of either feed grains -- such as corn, sorghum, barley, oats, and wheat -- or crop by-products -- such as cottonseed and soybean meal, meat scraps and meal, sugar beet pulp, and wheat and rice mill by-products.

California livestock and poultry producers, in 1974-1976, fed an estimated yearly average of $3.1 \mathrm{million}$ megagrams ( 3.4 million tons) of crop by-products and $4.7 \mathrm{mill}$ ion megagrams ( 5.1 million tons) of feed grains. During this same period, more feed grains were consumed by poultry -- $1.9 \mathrm{mill}$ ion megagrams (2.1 million tons) -- than by either beef or dairy animals [68]. Beef cows were fed $1.8 \mathrm{million}$ megagrams ( $2.0 \mathrm{million}$ tons), and dairy cows were fed $0.8 \mathrm{million}$ megagrams $(0.9 \mathrm{mj}$ llion tons). In terms of water use, feed grains used for feeding- account for only 28 percent of the California applied water indirectly consumed by livestock and poultry. About 50 percent of feed grains used in California feeding operations are shipped in from other states. These in-shipped grains use no California water in their production, and thus the indirect California water use associated with them is zero. Also, most barley, corn, and sorghum grown in major producing areas outside California, received very little or no applied irrigation water [102].

Dairy cows are the major consumers of crop by-products in California, consuming an estimated 1.4 million megagrams (1.5 million tons) in 1974-1976 [68]. Beef cattle and poultry each consumed about $0.9 \mathrm{million}$ megagrams ( $1.0 \mathrm{mill}$ ion tons) during this period. Crop by-products represent insignificant amounts of indirect water use because the crops they are derived from are grown for other purposes.

In summary, the dairy industry appears to be the greatest indirect user of California water associated with feed and forage crops, with beef cattle second. However, the exact magnitudes of this indirect applied water use are unknown. Nearly three-fourths of applied water used to grow livestock and poultry feed and forage crops are accounted for by hay and pasture; the remaining fourth is used to grow feed grains. In addition to consuming feed grains that use California irrigation water, the livestock and poultry industries used significant quantities of in-shipped feed grains and crop by-products, neither of which account for any indirect applied water use.

More details on water use by crop and feed and forage consumption by type of animal can be found in study I, from which most of the statistics cited in this section were taken [68].

1/ Some amounts of barley, corn, and sorghum and significant quantities of wheat are used for human or industrial purposes rather than for feeding livestock and poultry (Table 3 ). 


\section{CHAPTER IV}

THE LINEAR PROGRAMMING LIVESTOCK MODEL OF THE DEPARTMENT OF WATER RESOURCES

This chapter describes the linear programming model developed in this study. First, the purposes for developing the model and a general description of the model are briefly outlined and then both a simplified and complex model are described. The simplified model, which was developed and run to clarify the logic of the complex model, provides a general idea of the manner in which the complex model works.

The complex model, the one used to predict the economic behavior, is described next. This second model uses the same logic as does the simplified model and gives more detailed data on the regions, data sources and specified assumptions, and relationships actually used. These categories of data are organized in three sections: (1) the model regions, production and consumption centers; (2) a general description of the assumptions and relationships specified in the model objective function, activities and constraints; and (3) relationships and assumptions that apply specifically to the water and land resources aspects of the model.

At the conclusion of the chapter, the base run model results for 1978 are discussed and compared to actual 1976-78 and 1978 data.

\section{Purposes of the Complex Model}

The livestock linear programing model has been developed for two purposes:

- To project livestock feed crop acreage and feed crop water demand.

- To determine the sensitivity of feed crop acreage to changes in the costs of water and transportation. 
The objective of the model is cost minimization. Costs of crop and livestock production are minimized, subject to meeting consumer demand and resource constraint levels.

Common to all such linear programming models is an objective function row and activity columns. The inequality relationships between resources available and the activities required make up the body of the matrix, known in linear programming language as a tableau. The tableau mathematically ties together the activity costs, the physical input-output activity relationships, and the activity resource levels available and the marketing levels to be met. Another way to describe the tableau is that it is a set of linear simultaneous equations.

The tableau in the livestock model specifies crop and livestock production and transportation activities. The model attempts to capture much of the reality of the livestock picture in California by incorporating the major feed and livestock activities and allowing these activities to be transported from producing regions to consuming regions. One of the main strengths of the model is that it can capture both intrastate and interstate transportation. This feed and livestock mobility allows for a whole array of possibilities. For instance, beef can be grazed in one region, shipped to another region for fattening and slaughter, and shipped back to the first region for consumption. similarly, feeds produced in one region can be shipped to another region for consumption by livestock. These model relationships are mathematically described in much more detail in Appendix $B$, the simplified tableau at the back of this bulletin.

\section{The Model}

The model used to predict the economic behavior of California crop, livestock, and poultry producers uses logic that is very similar to that of this simplified model. However, it is much larger, with 560 rows and 435 columns, and has more intricate features. (The simplified model has 34 rows and 30 columns.) The following section describes the regions, the major features of the objective function, the activities, and the constraints. Because of their importance in this study, the crop rotational constraints and water-related features of the model are discussed in a subsequent section. Following that discussion, some of the other important aspects of the objective function, activities, and constraints are briefly outlined.

\section{Regions}

The model divides California into six regions (Figure 24) and places the rest of the United States into a seventh region (Figure 25). The rationale for determining these six regions is a result of tailoring the model's design to best address the water resources problem the model is attempting to answer: 1 and and water resource use associated with livestock and poultry production. 


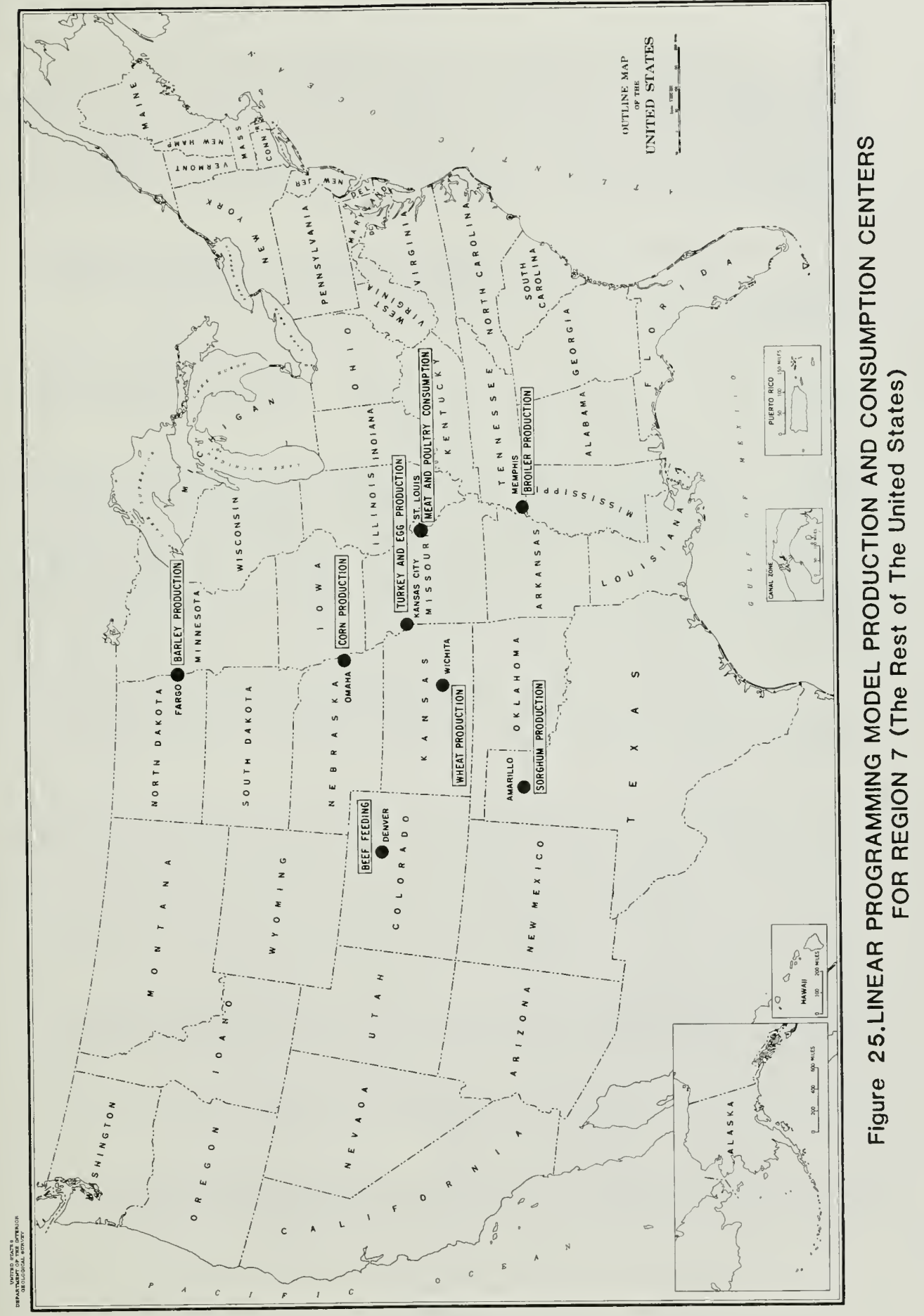


The Southern Tulare Lake, Northern Tulare Lake, and San Joaquin-Sacramento River Regions (Regions 1, 2, and 3) are crop-producing areas. These regions include most California feed and forage crop acreage. The Imperial Valley (Region 4) is a cattle-feeding region, and the southern Coastal and Desert (Region 5) and Northern California Bay and Mountain (Region 6) are large consuming areas. All regions were determined by county boundaries to facilitate data collection.

Region 1, Southern Tulare Lake, is a high-cost water region. Much of the water used for irrigation is relatively expensive. The 1978 typical water cost was $\$ 19.00$ per cubic dekametre (\$23.00 per acre-foot).

Region 2, Northern Tulare Lake, generally faces lower water costs and different growing conditions than does Region 1. Region 3, San Joaquin-Sacramento River, faces yet another set of growing conditions and water costs.

Regions 4, 5, and 6, Imperial Valley, Southern Coastal and Desert, and Northern California Bay and Mountain, are cattle feeding and consuming regions. Region 7 , the rest of the United states, is quite critical to the model results because this region specifies California's competitors in livestock and feed crop production. Because of this fact and the vast geographical size of Region 7, each model activity has a different geographic center of production (Figure 25).

The model is based on the assumption that cattle feeding is taking place in Denver, on the western rim of the southern and western plains cattle-feeding areas. Denver was chosen because it is roughly equidistant from the Texas, Kansas, and Nebraska feeding regions.

Kansas City, Missouri, was chosen as a production center in the model for turkey and egg production. Turkey production is concentrated in the northern and central plains and the Southeast but no one region truly dominates egg production in the U. S. outside California. Therefore, Kansas City was chosen as a center of turkey and egg production in the rest of the United states. Broiler production is centered in Memphis, Tennessee, because of the dominance of the southeast in U. S. broiler production.

Feed crop centers of production for Region 7 were also chosen on the basis of proximity to California and the major production regions. These are:

Barley - Fargo, North Dakota
Corn - Omaha, Nebraska
Sorghum - Amarillo, Texas
Wheat - Wichita, Kansas

These regions lie generally in the western parts of the principal producing areas of the United states. 
The consumption center for the entire United States is St. Louis, Missouri. This city was chosen for the model on the basis of U. S. Bureau of Census data, which currently show the U. S. center of population slightly southeast of St. Louis. The southwestern shift taking place in U. S. population would suggest that the center of population is moving to a point just south of st. Louis.

Assumptions and Relationships of Major Model Activities, the objective Function, and the Constraints

The regions and the activities taking place in these regions are shown in Figures 26 and 27 . The model looks at seven livestock activities (Figure 26), eleven feed activities (including four feed concentrate activities and four by-product supplement activities), (Figure 27 ).

The linear programming livestock model takes the perspective of a single integrated firm that controls all crop and livestock production. The firm's objective is to minimize the cost of providing final livestock products to consumers. The objective function activities are grouped into eight major categories:

- Grass production and conversion to Animal Unit Months (AUM)

- Feed crop/feed by-product supplement production and conversion to Total Digestible Nutrients (TDN)

- Livestock AUM consumption

- Livestock TDN consumption

- Water

- Feed transportation

- Intermediate 1 ivestock product transportation

- Final livestock product transportation

Transportation activities account for most of the model activities. The large number of possible transportation activities pose a computational problem because they result in a matrix that is expensive to invert, in terms of computer time. Consideration of all possible transportation alternatives could result in an unnecessary and expensive set of analyses. To mitigate this problem, a simplifying set of assumptions was made, reflecting the existing institutional and economic situation. These assumptions are:

- No grain was shipped from California to the rest of the United States. 


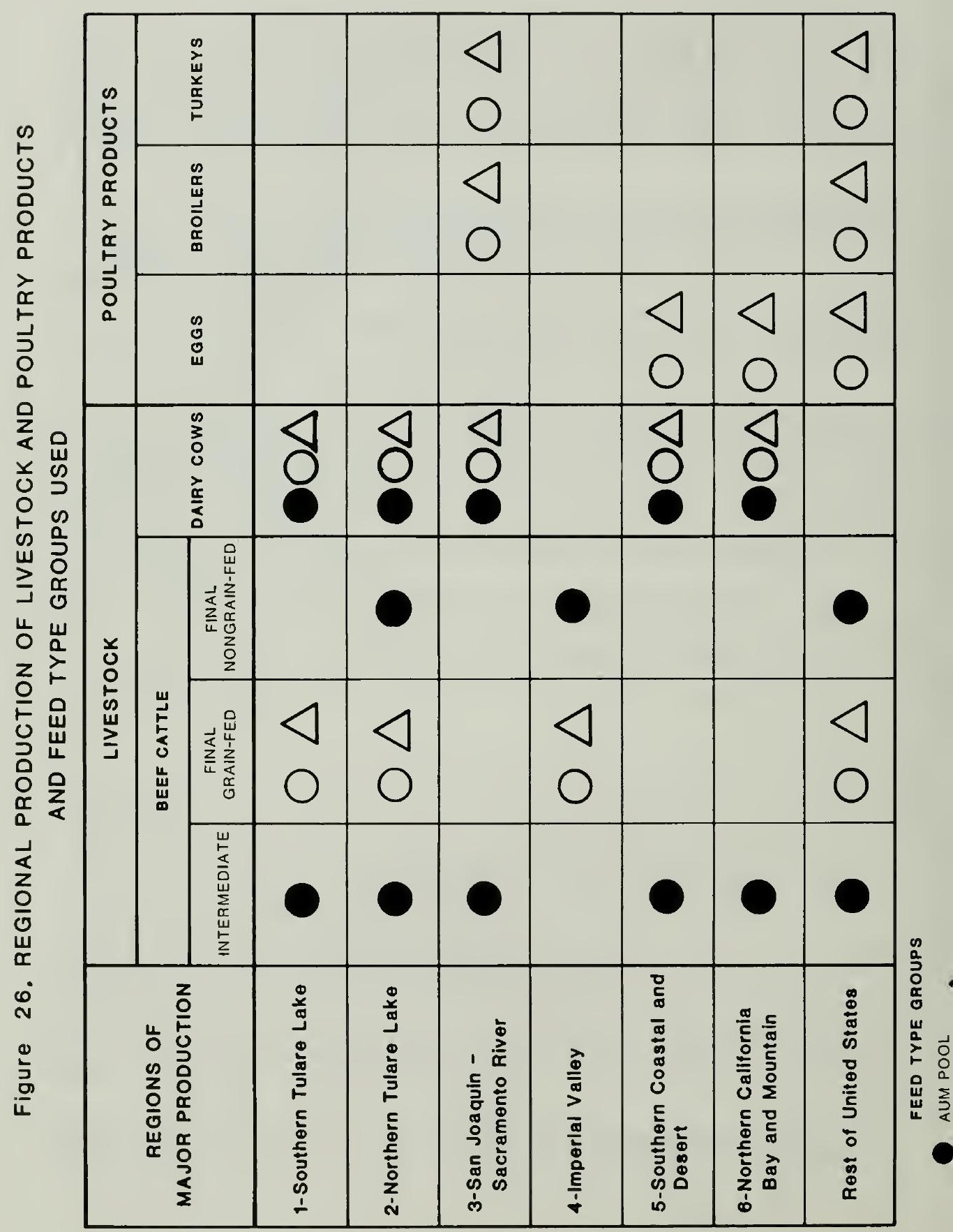




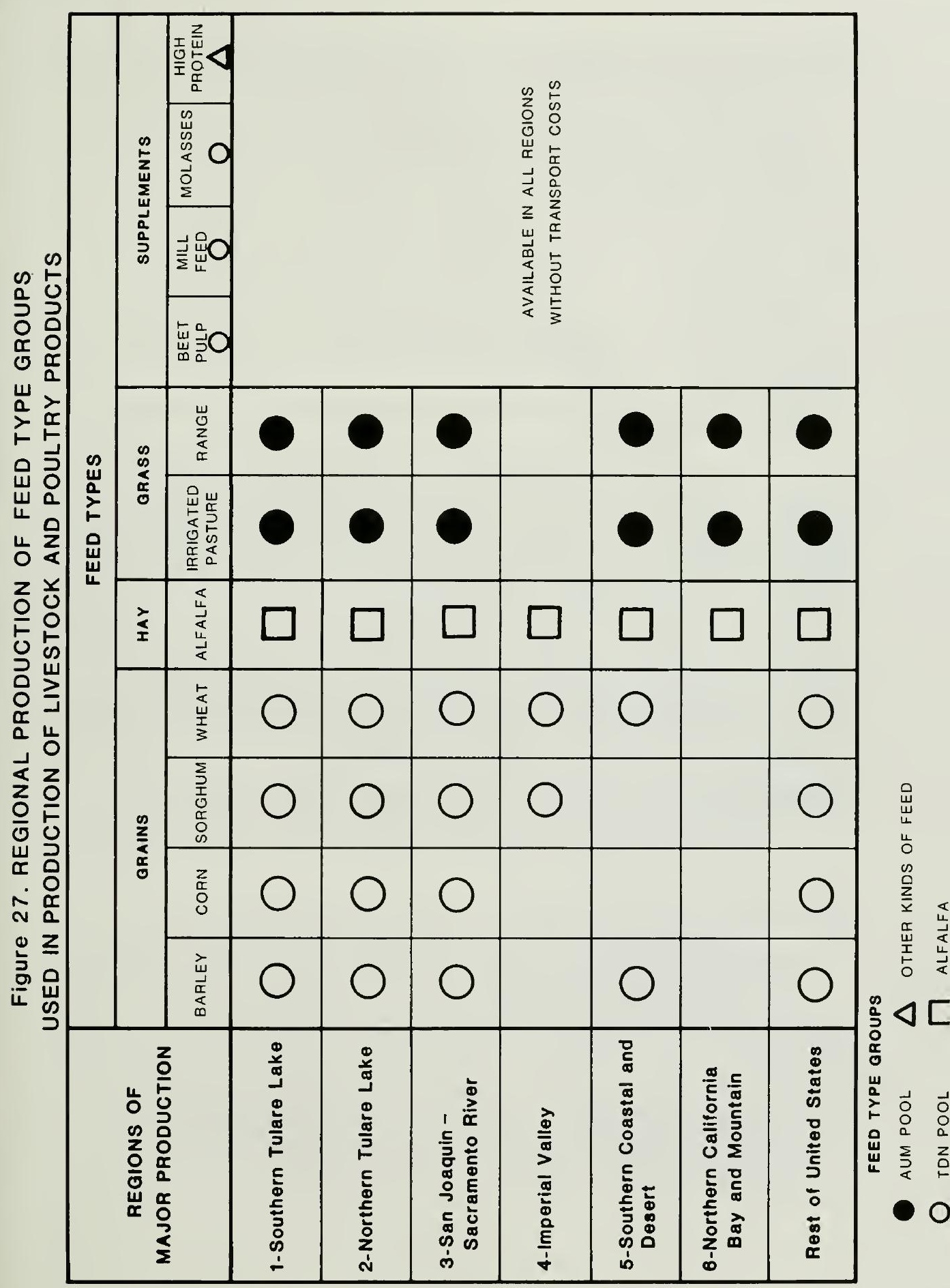


- No finished slaughtered beef was shipped from California to the rest of the United States.

- California's supply of milk satisfies California's demand for milk (that is, no milk was shipped from the rest of the United States to California and none from California to the rest of the United States.)

- No eggs were shipped from the rest of the United States to California.

- No turkeys were shipped from the rest of the United States to California.

- No broilers were shipped from California to the rest of the United states.

- No alfalfa was shipped from California to the rest of the United states.

The linear programming model includes a variety of constraints. Resource constraints for water and soil indicate the availability of these two resources. Feed crop acreage constraints reflect both crop rotation and crop market conditions. other constraints indicate the demand for resources and livestock products. The model also contains several special right-hand-side features. For instance, AUM and TDN "pools" are established. Irrigated pasture and range contribute to the AUM pool from which intermediate beef and dairy can feed. Grains and crop by-products contribute to the TDN pool from which all livestock can feed. Another special right-hand- side feature is "balancing" in the transportation sector. This balancing forces the supply of transportation to equal the demand for transportation for feed and intermediate and final livestock products.

Assumptions and Relationships of Activities, the Objective Function, and Constraints Specific to Land and water Resources costs are:

Specific assumptions relating to water activities and

(1) Water costs are typical. They were developed for the California Agricultural Resources Model (CARM). Differences between CARM and the Department of Water Resources' regions were adjusted for, according to reasonable judgment [58].

(2) Applied water use coefficients by crop were developed by DWR [37].

(3) The irrigated and nonirrigated portions of the barley and wheat acreages were provided by the California crop and Livestock Reporting Service and verified by the Department of Water Resources 1 and use survey data [86]. 
Water availability is assumed to be unlimited. Applied water is only limited by crop acreage maximum constraints. Water availability was not limited because it is possible to transfer water from other crops to grow feed grains.

Maximum and minimum acreage constraints on California crops are of special importance in the model, because they are crucial determinants of the optimal model solution.

Maximum rangeland constraints depend on the availability of such land. Rangeland is a fixed resource. About $14.6 \mathrm{mill}$ ion hectares (36 million acres) of rangeland exist in California. A very small amount of the total is used for second-home subdivisions, but nearly all rangeland has few alternative economic uses, other than cattle and sheep grazing. Therefore, owners of rangeland will continue to use it for grazing, even if the productivity is relatively low, because the next best alternative is to allow the land to stand idle and to receive no income from it.

Since rangeland is a fixed resource and has so few alternative economic uses besides cattle grazing, there is a strong probability that it will continue to be used for cattle grazing at levels similar to present land use patterns. Therefore, rangeland minimum and maximum acreage levels close to those observed presently are established in the model. Range maximums and minimums are derived by adjusting county rangeland data [85] 10 percent up and down to reflect (1) fluctuations in use and (2) the low opportunity cost of rangeland.

Other feed and forage crops also face maximum and minimum acreage limitations. These constraints are determined by market conditions, institutional factors, soil types, rotational requirements, and other considerations. For example, the amount of irrigated pasture produced is limited by the relative price of animals or animal products derived from grazing on this land, in relation to the number and value of competing uses for land of that type. Maximum and minimum irrigated pasture acreage constraints were set that attempted to take these factors into account.

As another example, only so much barley will be grown in the short run, even if barley prices are high and demand is relatively limitless. One reason for this maximum barley acreage is because the relative prices of other crops affect the barley supply curve; an amount less than that which is economically possible will be grown, even with high prices, because barley traditionally has been a relatively low-value crop in comparison to fruit and vegetable crops. This same sort of reasoning applies to the other feed and forage crops.

At the other extreme, there will also always be minimum acreage levels for feed and forage crops. Wheat and barley are relatively easy crops to grow. They need relatively little nitrogen. Crop rotational needs are very important, and feed 
crops, particularly barley, wheat, and alfalfa have traditionally been very important in crop rotations. Rotation of low-value feed crops is a necessary production input for higher value crops over a 3-year to 4-year planning period. Logically, without rotational constraint minimums for low-value feed crops and marketing constraint maximums for high-value crops, a rational producer would not produce feed crops at all, if climate and soil conditions were to allow the producer to grow more highly valued crops.

Most feed crops in the model have important functions in crop rotations. For example, alfalfa has deep roots and is considered to be useful in breaking up the soil. Other feed crops are also rotated for pest control and soil management.

In addition to minimum acreage requirements for physical rotation, some feed and forage crops will be grown in preference to others for other reasons. About 142 thousand hectares

( 350 thousand acres), of irrigated pasture in the state may have no other significant cropping possibilities [86]. Moreover, some growers may prefer to produce certain crops because they are easier to grow, because the grower is more knowledgeable about certain crops or because there may be limited capital to finance production of other crops. For all the above reasons, the model specifies minimum and maximum crop acreages for the model by region.

Irrigated pasture and feed crop maximums and minimums are determined on the basis of extreme points for six years, using county Commissioner's Reports data [11]. The maximum acreage harvested for each county for 1972-1977, totaled for each region, provides the maximum. The minimum is derived in a similar manner.

Ten percent more acreage was added to the maximums to make sure the model had a reasonable amount of freedom to choose crop production patterns. If crop prices are high enough, growers may plant ten percent more acreage than the highest amount grown in 1972-1977. For the minimum, a similar procedure was applied; ten percent was subtracted from the extreme points for each region for nonzero acreage minimums.

Another commonly used way to establish acreage maximum and minimum constraints is to choose specific crop rotations. For example, a cotton-tomato-cotton-sugar beet rotation would imply only half the acreage in any one year can be planted to cotton. Because of the complexity of specifying such a rotation for a statewide model and because the model is limited to looking at field crops, this method was rejected. Because the minimum and maximum allow a great deal of choice, the method chosen is probably fairly reasonable. However, it should be pointed out that model projections show most regional crop acreages producing at their rotational minimums. 
The model was run and then compared to estimates of actual data for 1978 and for 1976-78 (Table 4). Both comparisons were made because 1978 technology, prices, and costs were used in the model as the most recent data available, but per capita consumption was set in terms of 1976-78 averages to avoid extremes in years. Since per capita beef consumption declined by 4 kilograms ( 9 pounds) during this period, the 1976-1978 comparison may be more relevant, and these are the data referred to here, unless otherwise specified.

The estimates of actual levels of some of the model activities are not published. These estimates of actual levels were derived from the best information available. Feed grains consumed are based on livestock and poultry numbers for the period specified (1978 or 1976-1978). Feed grain consumption per animal in 1974-1976, as estimated by the University of California [68], was assumed for 1976-1978. Both grain produced in California and grain shipped from other states are consumed by livestock at the same percentages, as recent estimates show [68]. Alfalfa production excludes those quantities that are used to produce pellets and meal. Total beef consumption is based on population and California per capita consumption estimates; beef produced in California is based on feedlot marketings at $454 \mathrm{kilograms}$ $(1,000$ pounds) final weight.

Numbers of poultry consumed in California and poultry shipped to other states are difficult to estimate; the only really reliable figures represent California production. Out-shipment estimates are based on the ten-year averages, using the estimation methodology provided by the University of California [67] . California consumption estimates are derived from the same source.

The base run results are quite variable, but most of the important parameters are estimated reasonably well. Total feed grains used in California livestock production happened to be 100 percent of actual data in both periods. California-produced feed grains are estimated at 86 percent of reliable estimates. The residual between total grain consumption and California-based production is 111 percent of estimated figures.

Alfalfa hay and irrigated pasture, as predicted by the model, are 7-16 percent lower than reliable estimates for 1976-1978. This occurred in part because of the specification of the model; the model did not include horses, although they are significant consumers of hay and pasture. A conservative estimate is about one million tons of all types of hay [68]. Unfortunately, how much hay and pasture horses consume is difficult to estimate. 
COMPARISON OF THE 1978 LINEAR PROGRAMMING MODEL BASE RUN WITH REFERENCE 1978 DATA

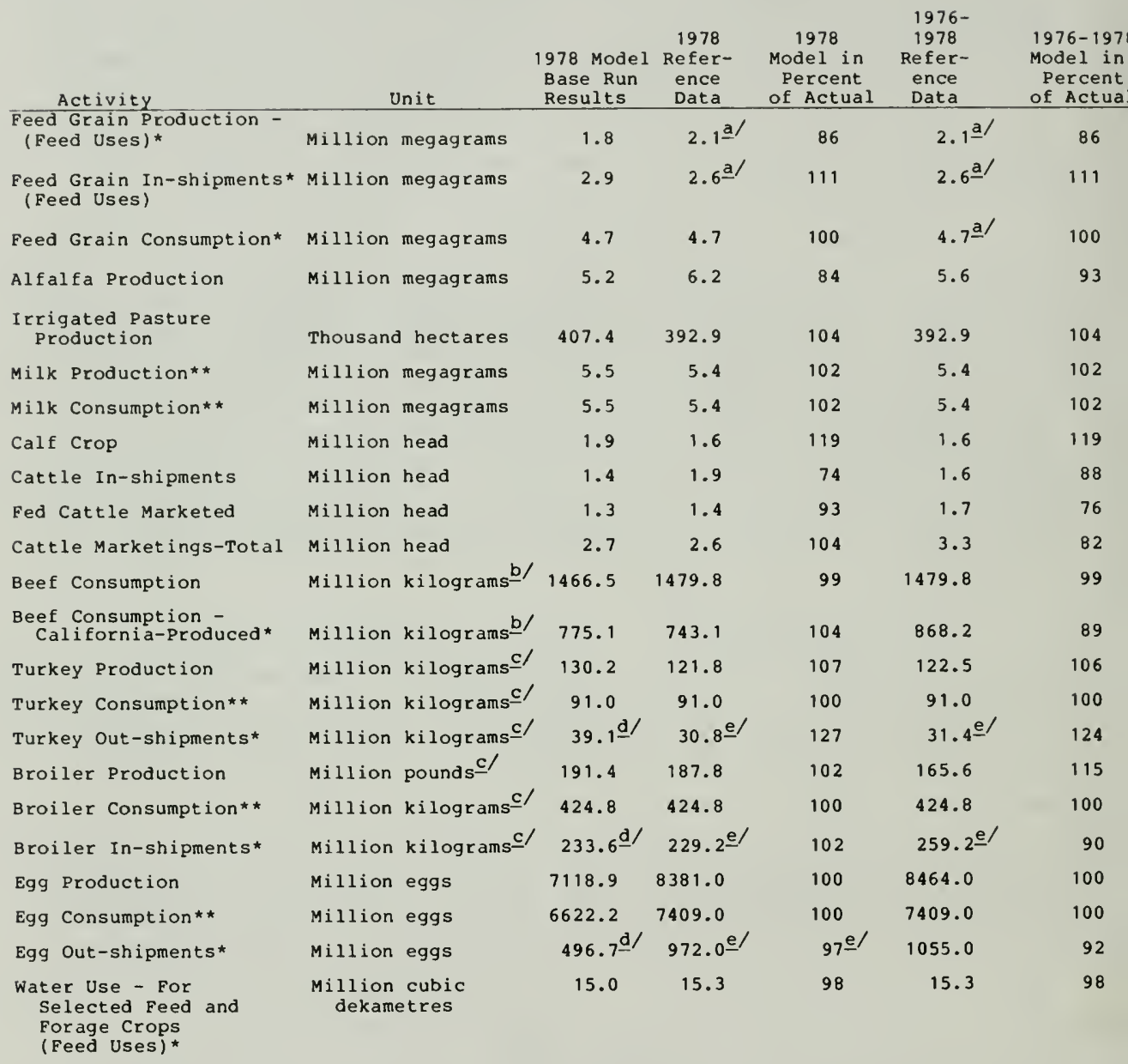

Note: In the cases of many of the variables the model predicts, actual published data are not available. The actual values are estimated in these cases and the activity title is marked with an asterisk (*). Some model activities would be expected to be equal to or close to 100 percent by model design. Those activity titles are marked with double asterisks $(* \star)$.

a/ Derived from: "Trends in California Livestock and Poultry Production, Consumption and Feed Use: 1961-1978".

b/ Carcass weight. Assuming 1,000-1b. siaughter weight and 60 o efficiency.

c/ Ready-to-cook basis.

d/ Derived. Based on estimates of the average percentage of California production shipped out for the last ten years.

e/ Derived. Based on the residual of California population times per capita consumption minus California production. 
Milk production was forced to equal milk consumption by model design. The fact that milk production and consumption are close to actual levels is also due to this design, which did not allow milk to be shipped in or out of California.

The beef cattle marketing figures were not predicted as well as many of the other model activities. Total cattle marketings were 82 percent of 1976-1978 actual data; Californiaproducted beef was 89 percent of estimated actual levels. Feedlot marketings were 76 percent of actual levels. The model chose cattle feeding as taking place almost exclusively in the Imperial valley, relying almost totally on feeder cattle shipped into the region from out of the state.

The poultry production figures show mixed results, mainly because of the difficulty of estimating California per capita consumption and shipments out of California. Consumption levels are 100 percent of actual data; as with the other products, these were specified by the model. The residual of production and consumption is defined as shipments in and out of the state.

Production figures are, therefore, the most dependable data for comparisons. Poultry production by type is fairly reasonable; turkeys are 106 percent, broilers are 115 percent, and eggs are 100 percent of actual. The percentages of implied out-shipments and in-shipments diverge farther because the basis of comparison is smaller.

Water use predicted by the model came reasonably close to 1976-78 and 1978 estimated actual levels, at 89 percent. The actual levels are based on the derived acreage for feed and forage crops used by the University of California [68]. The applied water coefficients are from DWR [86]. The actual figures differ from the ones shown in the University of California report [68] because of the difference in years, the exclusion by the model of corn silage, oats, and other hay, and the fact that this report uses DWR applied water coefficients rather than University of California figures. 


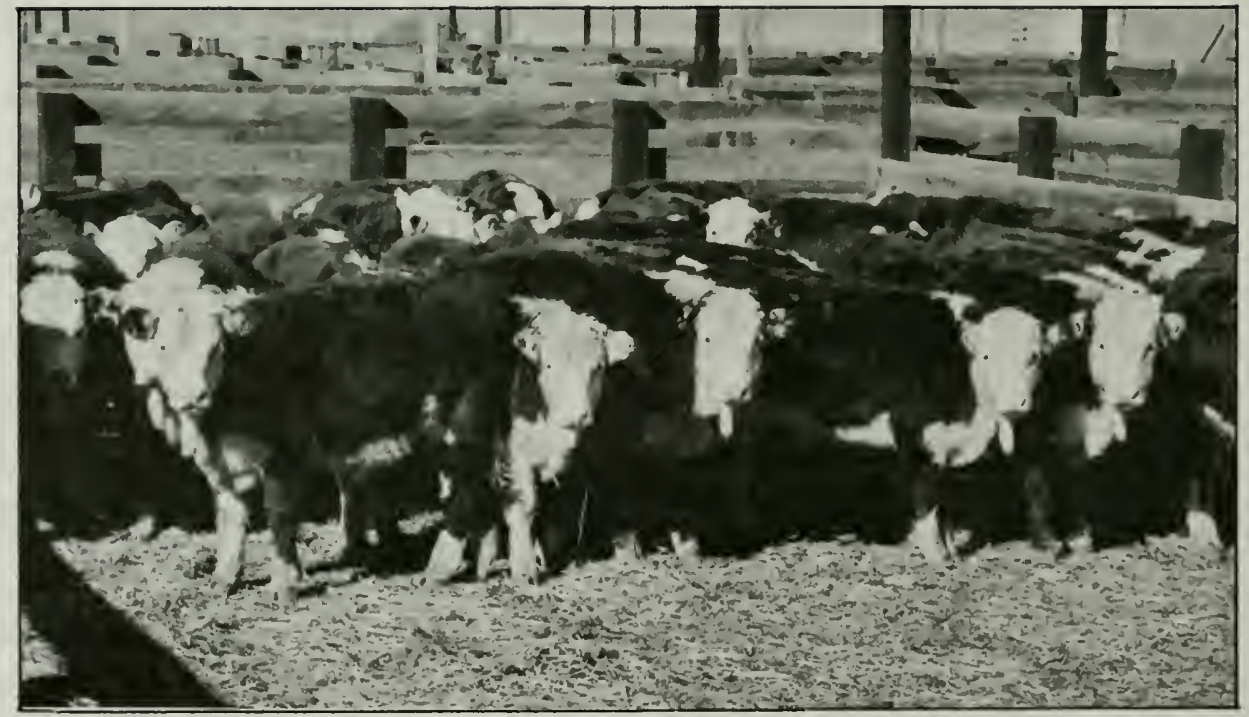

Beef cattle usually spend the first part of their lives on range or pasture and are then sold to feedlots to be fattened for slaughter. These feeder cattle are ready for sale. 


\section{CHAPTER V}

\section{PROJECTED ASSUMPTIONS AND RESULTS AND SENSITIVITY OF RESULTS FOR 1990, 2000, and 2010}

\section{Projection Assumptions}

To make the projections to 1990,2000 , and 2010 , examination of likely assumptions and relationships is necessary. These are outlined in this chapter. Many can be assumed to be reasonably constant or, for practical purposes, unlimited. Examples of these are California's rangeland (assumed constant) and soil and water availability in the rest-of-the-U. S. (Region 7) (assumed unlimited). Others need to be assessed to determine the relative importance of possible changes as they may affect California's comparative advantage with respect to Region 7 . These include, among others, crop yields, water costs, and transportation costs. other information necessary to run the model, such as population projections, is obtained from other sources.

All assumptions, except those for water costs, water conservation, and transportation costs, and per capita consumption, are treated in this section of the chapter. These factors are covered separately in detail in subsequent sections because they are likely to be the most important considerations in the projections.

As in the base run model, the exclusion of sheep and swine is assumed since these traditionally have used few water-related resources. All other assumptions made about the activities and constraints to be used in the base run model are also made for the projections, except where specified. (Appendixes A and B provide more detail about the 1978 base run assumptions.)

Crop by-products are assumed to increase in proportion to population, since the by-products are generally derived from commodities for consumption by the general population. This assumption may be crude, but given its importance in relation to the rest of the model inputs, it is considered reasonable. 
It should be noted that shifts in specific by-products may occur. For example, sugar beet acreage may decline due to the substitution of corn sweeteners for sugar beets. However, other by-products such as brewers" "spent" grains may increase accordingly. In 1974-1976, sugar beet,pulp composed about 21 percent of low-protein by-products 2 , excluding fats and vitamins and mineral supplements. Grain mill by-products composed 25 percent; molasses, 29 percent; and other miscellaneous crops composed the remaining 25 percent [68].

Soybean meal, which is currently shipped from other states, composed 26 percent of the high-protein supplements. Much of the rest of the high-protein by-products fed to California livestock were cottonseed meal (19 percent) and fish meal (32 percent) [68].

In a relative sense, by-product supplies are not assumed to be more or less expensive than they are today, in view of the above relationships. Although the cost of high-protein by-products may decline in the future if cotton production continues to increase, relative by-product prices are assumed to remain constant in real terms.

Rangeland and feed crop yield productivity is assumed constant. Future increases in productivity for all crops and livestock do not differ significantly between California and the rest of the U. S., according to a recent USDA report [109].

The minimum, maximum, and feed uses proportions of feed and forage crops are assumed to be constant over 1978 levels. Minimum and maximum acreage constraints are constant because one would, for the most part, expect California feed and forage crop production to slow its growth rate, as recent data suggests [12]. The feed use proportion is constant because there is no obvious reason to change them.

Water Costs

Water costs are expected to increase at various rates due to increases in energy costs for pumping ground water and current institutional pricing policies for federal and state water. Likely federal water prices are documented in a DWR memorandum [27]. In terms of 1978 real prices, water costs are expected to increase by factors of as much as 1.5 times by $1990,2.0$ times by 2000 , and 2.5 times by 2010 (Table 5). This assumes (1) all other prices are constant and (2) energy-related costs are the only costs that are increasing. This is probably a rather pessimistic scenario, since other costs and farm commodity prices are likely

2/ All by-products, except soybean meal, cottonseed meal, fish meal, and meat meal. 
TABLE 5

CURRENT AND PROJECTED REAL / TYPICAL WATER COSTS

FOR LINEAR PROGRAMMING MODEL

\begin{tabular}{|c|c|c|c|c|c|c|c|c|c|}
\hline & \multirow[b]{2}{*}{ Region } & \multicolumn{2}{|c|}{$\begin{array}{l}\text { Typica } 1978 \\
\text { Water Costs }\end{array}$} & \multicolumn{2}{|c|}{$\begin{array}{c}\text { Real Typical } \\
1990 \text { Water } \\
\text { Costs }\end{array}$} & \multicolumn{2}{|c|}{$\begin{array}{l}\text { Real Typical } \\
2000 \text { Water } \\
\text { Costs }\end{array}$} & \multicolumn{2}{|c|}{$\begin{array}{l}\text { Real Typical } \\
2010 \text { Water } \\
\text { Costs }\end{array}$} \\
\hline & & $\begin{array}{l}\text { per } \\
\text { dam }\end{array}$ & $\begin{array}{l}\text { per } \\
\text { ac-ft }\end{array}$ & $\begin{array}{l}\text { per } \\
\text { dam }\end{array}$ & $\begin{array}{c}\text { per } \\
a c-f t\end{array}$ & $\begin{array}{l}\text { per } \\
\text { dam }^{3}\end{array}$ & $\begin{array}{c}\text { per } \\
a c-f t\end{array}$ & $\begin{array}{l}\text { per } \\
\text { dam }\end{array}$ & $\begin{array}{c}\text { per } \\
\mathrm{ac}-\mathrm{ft}\end{array}$ \\
\hline 1 & Southern Tulare Lake & $\$ 19$ & $\$ 23$ & $\$ 28$ & $\$ 35$ & $\$ 37$ & $\$ 46$ & $\$ 47$ & $\$ 58$ \\
\hline 2 & Northern Tulare Lake & 10 & 12 & 13 & 16 & 19 & 24 & 24 & 30 \\
\hline 3 & $\begin{array}{l}\text { San Joaquin - } \\
\text { Sacramento River }\end{array}$ & 6 & 7 & 6 & 8 & 8 & 10 & 14 & 18 \\
\hline 4 & Imperial Valley & 5 & 6 & 5 & 6 & 5 & 6 & 5 & 6 \\
\hline 5 & $\begin{array}{l}\text { Southern Coastal and } \\
\text { Desert }\end{array}$ & 11 & 13 & 16 & 20 & 21 & 26 & 27 & 33 \\
\hline 6 & $\begin{array}{l}\text { Northern California } \\
\text { Bay and Mountain }\end{array}$ & 7 & 9 & 10 & 12 & 12 & 15 & 19 & 23 \\
\hline 7 & $\begin{array}{l}\text { Rest of the United } \\
\text { States }\end{array}$ & 4 & 5 & 6 & 8 & 8 & 10 & 10 & 13 \\
\hline
\end{tabular}

a/ Real, in terms of 1978 dollars.

Dam $^{3}$ - cubic dekametre.

Ac-ft - acre-foot.

to be increasing as well. However, these costs and prices will also, in all likelihood, increase for producers in Region 7.

As added support of a 2.5 times real energy cost increase in 2010, the University of California assumes a 100-percent energy cost increase in real terms for 1985 [46]. Also, gasoline and fuel oil cost more in 1979 than in 1978 (52 percent and

62 percent, respectively) [118]. In real terms, these increases were 39 percent (gasoline) and 49 percent (fuel oil) because the Consumer Price Index (CPI) for a market basket of consumer goods was 13 percent higher in 1979 than in 1978. The year 1979 will probably be remembered as the time in which an adjustment was made between relatively low energy prices and higher ones. Therefore, one would not expect these yearly percentage increases in costs to 
continue to 2000. The 2.5 factor for cost increases allows for some degree of energy substitution and a varying degree of pumping efficiency that may take place.

Costs of water supplied by the state water Project to the Kern county Water Agency are expected to increase to an average of $\$ 38 /$ cubic dekametre $(\$ 47 /$ acre-foot) by 1990 , twice the 1978 cost [66]. However, water prices can be expected to be somewhat lower, when costs of all sources of water are melded. Federal (Central Valley project) and local surface water, which represents a much larger percentage of the total water applied, will likely increase at a much slower rate because of the institutional nature of the federal water market and because local water projects require little pumping and thus use less energy. These facts are reflected in the water costs shown in Table 6 and the acreages of various high water-using crops grown in these areas (Table 2 ).

Much federal water is contracted for at relatively low prices, considering the rate of inflation, and many of these contracts do not expire until the mid-1990s. Even then, prices are not expected to increase more than by a factor of 3 , with the most expensive Central valley Project water costing from $\$ 8$ to $\$ 12$ per cubic dekametre ( $\$ 10$ to $\$ 15$ an acre-foot) [28].

The cost of ground water should increase roughly in proportion to energy costs. The cost of electricity represents about 26-44 percent of the cost of such water [56]. Electricity cost increases in California have not surpassed the cost of living

TABLE 6

ACTUAL AND PROJECTED CALIFORNIA PER CAPITA DEMAND LEVELS FOR MEAT, MILK, POULTRY AND EGGS

\begin{tabular}{|c|c|c|c|c|c|c|c|}
\hline & $\begin{array}{l}\text { Beef and } \\
\text { Veala } \\
\text { in kgs } \\
\text { (in lbs) }\end{array}$ & $\begin{array}{c}\text { Milk } \text { - } \\
\text { in kgs } \\
\text { (in lbs) }\end{array}$ & $\begin{array}{l}\text { Pork } \text { a/ } \\
\text { in kgs } \\
\text { (in lbs) }\end{array}$ & $\begin{array}{l}\text { Muttona/ } \\
\text { in kgs } \\
\text { (in lbs) }\end{array}$ & $\begin{array}{l}\text { Turkeys } \\
\text { in kgs } \\
\text { (in lbs) }\end{array}$ & $\begin{array}{l}\text { Chickens } \\
\text { in kgs } \\
\text { (in lbs) }\end{array}$ & $\begin{array}{l}\text { Eggs } \\
\text { in } \\
\text { numbers }\end{array}$ \\
\hline $\begin{array}{l}\text { 1975-1977 Average Per } \\
\text { Capita Consumption }\end{array}$ & $(145)^{65.8}$ & $\begin{array}{l}248.6 \\
(548)\end{array}$ & $\begin{array}{l}26.8 \\
(59.0)\end{array}$ & $\begin{array}{l}0.9 \\
(1.9)\end{array}$ & $\begin{array}{l}4.1 \\
(9.0)\end{array}$ & $\begin{array}{l}19.5 \\
(42.9)\end{array}$ & 297 \\
\hline $\begin{array}{l}1990 \text { Projected Per } \\
\text { Capita Consumption }\end{array}$ & $(140)^{63}$ & $\begin{array}{l}249.5 \\
(550)^{-}\end{array}$ & $\begin{array}{l}23.6 \\
(52.0)\end{array}$ & $\begin{array}{l}1.5 \\
(3.2)\end{array}$ & $\left(\begin{array}{c}5.4 \\
(12.0)\end{array}\right.$ & $\begin{array}{l}24.4 \\
(53.8)\end{array}$ & 285 \\
\hline $\begin{array}{l}2000 \text { Projected Per } \\
\text { Capita Consumption }\end{array}$ & $(150)^{68}$ & $(540)$ & $\begin{array}{l}24.1 \\
(53.2)\end{array}$ & $\left(\begin{array}{l}1.4 \\
(3.0)\end{array}\right.$ & $\begin{array}{c}5.8 \\
(12.8)\end{array}$ & $\begin{array}{l}25.6 \\
(56.5)\end{array}$ & 285 \\
\hline $\begin{array}{l}2010 \text { Projected Per } \\
\text { Capita Consumption }\end{array}$ & $(155)^{70.3}$ & $\begin{array}{l}240.4 \\
(530)^{4}\end{array}$ & $\begin{array}{c}24.7 \\
(54.4)\end{array}$ & $\begin{array}{l}1.3 \\
(2.8)\end{array}$ & $\begin{array}{c}6.0 \\
(13.2)\end{array}$ & $\begin{array}{l}26.6 \\
(58.7)\end{array}$ & 285 \\
\hline
\end{tabular}

a/ Carcass weight basis.

b/ Fresh equivalent basis.

c/ Ready-to-cook basis.

Source: [46] 
increases by much for the past several years [78], and they are not likely to exceed the overall cost of living by much more than 2 percent between now and 1990 [39]. No doubt conservation and nonfossil fuel electricity sources have influenced this very optimistic scenario. However, pumping depths are also likely to continue increasing, raising the cost of ground water further.

Water Conservation

The assumption is made that 5 percent less gross applied water will be needed per crop for 1990 and 10 percent less by 2000. These assumptions entail quite a few developments [22] and are assumed to be spurred on by increasing water costs and other factors.

Most feed and forage crops are grown in areas where relatively cheap water is available (Table 1). Little incentive is present for conservation. However, in all likelihood, opportunities for some conservation exist in these areas.

Water cost increases, conservation education and social pressure, if coupled with possible tax incentives, should eventually provide some incentives for agricultural water conservation in much the same way they are currently influencing businesses and individuals to conserve energy. Even where water is currently used efficiently, deficit irrigation and reuse of brackish water on barley and other field crops could possibly take place without significant yield reductions $\{81$ and 90$\}$.

Given these possible developments, 10 percent conservation in applied water by 2000 does not seem unlikely.

Transportation Costs

Significantly, the energy cost component of rail and truck transportation has been quite small in recent times. The DWR input-output model shows both rail and truck energy costs at less than 5 percent of total costs. Wages and salaries, maintenance costs, and fixed investment costs were 60 percent (for rail) and 50 percent (for trucking) of total costs for rail and truck transportation in 1976 [33]. These costs are based on 1967 energy costs, before the 1973 Arab oil embargo.

The outlook for energy conservation by trucking and rail carriers is fairly bright. In experiments in 1977 with a variety of devices, railroads saved from 10-24 percent of their normal energy use [113]. This same report projected that the trucking industry should be able to save 16 billion gallons of fuel by 1990. This savings will be accomplished by devices that reduce air resistance, by lower travel speeds, by use of radial tires, and by more fuel-efficient engines [113]. 
In view of these data and likely developments, transportation costs were increased to reflect up to a 4 times increase in energy costs by 2010 , in real terms. Only the fuel cost component, conservatively estimated to be 10 percent of 1978 transportation costs, was increased. Increases in the fuel cost component of transportation costs are assumed to take place, since energy costs are expected to increase more rapidly than will other costs. Energy-related transportation costs are assumed to increase by a factor of 2 times 1978 levels by 1990,3 times by 2000 , and 4 times by 2010 .

\section{Per Capita Consumption}

Per capita consumption is likely to increase at the levels shown in Table 6 . These are based on recent USDA and University of California Cooperative Extension studies [46] [98] and expert opinion of members of the Livestock Advisory Committee and others. These projections take into account differences between per capita consumption in California and the rest of the United States [65].

\section{Projection Results for 1990,2000 , and 2010}

Tables 7 and 8 summarize the statewide crop, livestock, and poultry projections for 1990, 2000, and 2010. Tables 9 and 10 show percentage changes from the base run for these years.

The model shows only changes relating to livestock and poultry production. Exports and direct human and industrial feed uses are not considered.

TABLE 7

ACTUAL AND PROJECTED FEED AND FORAGE CROP PRODUCTION IN CALIFORNIA

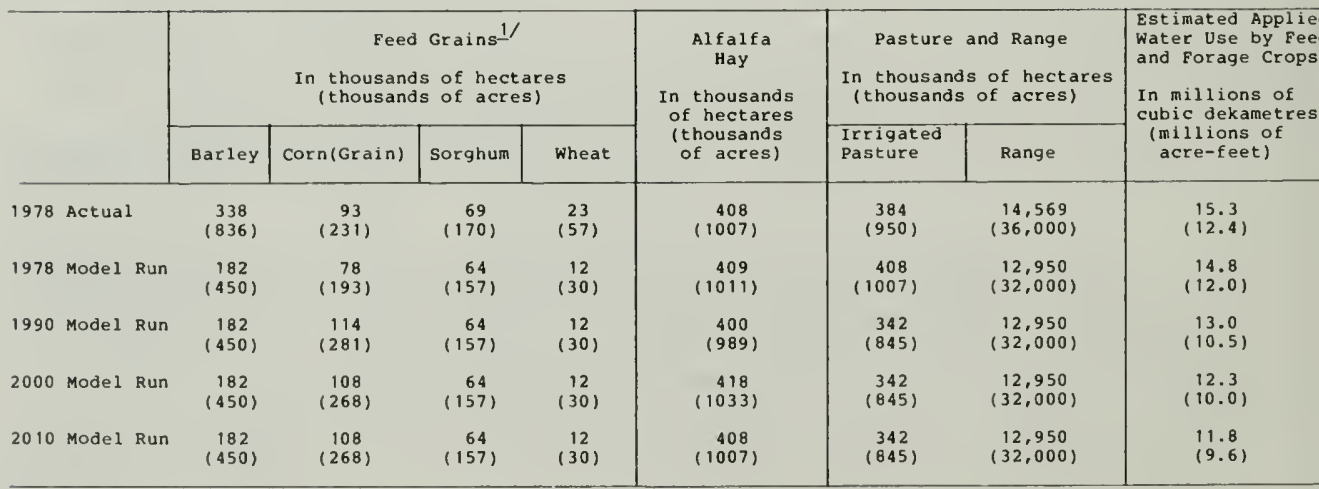

1/ Portions of crops used for feed. 
TABLE 8

ACTUAL AND PROJECTED LIVESTOCK AND POULTRY PRODUCTION IN CALIFORNIA

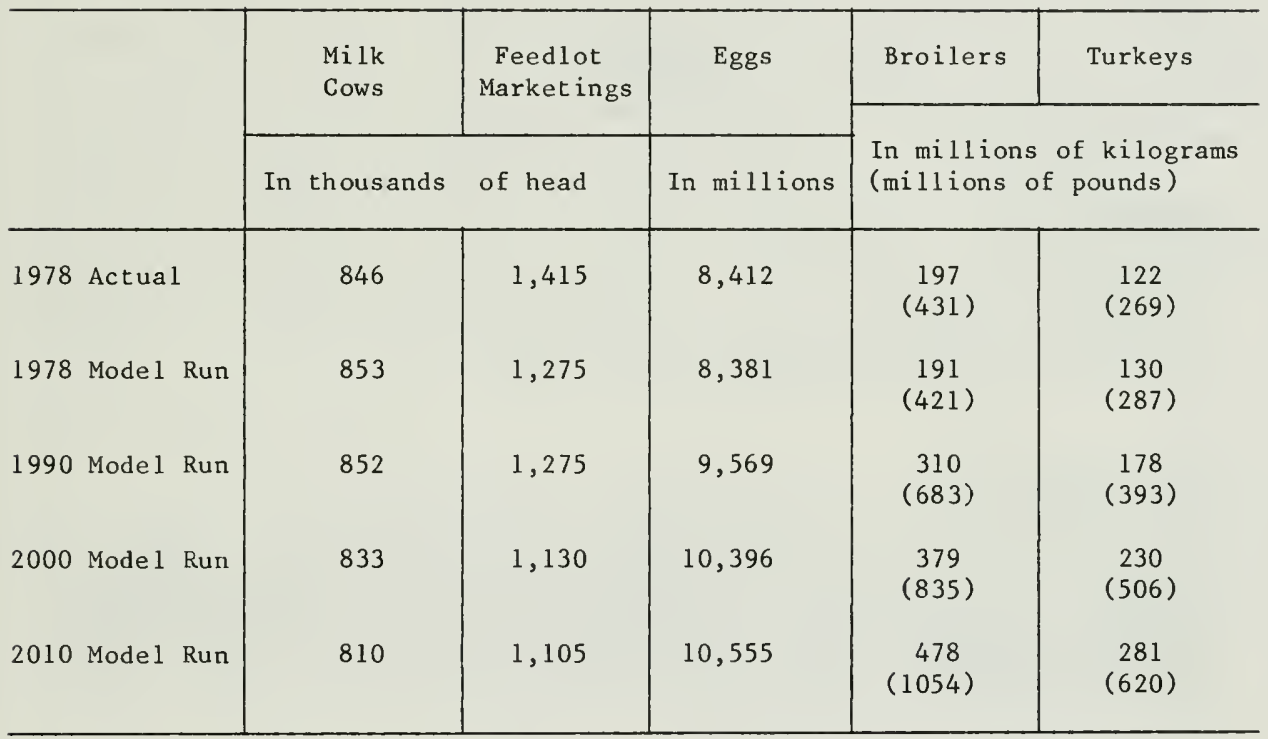

TABLE 9

PROJECTED PERCENTAGE CHANGES IN FEED AND FORAGE CROP AREA FROM THE 1978 MODEL BASE RUN

\begin{tabular}{|c|c|c|c|c|c|c|c|c|}
\hline & \multirow[b]{2}{*}{ Barley } & \multicolumn{3}{|c|}{ Feed Grains } & \multirow{2}{*}{$\begin{array}{c}\text { Alfalfa } \\
\text { Hay }\end{array}$} & \multicolumn{2}{|c|}{ Pasture and Range } & \multirow{2}{*}{$\begin{array}{l}\text { Applied } \\
\text { Water Use, } \\
\text { Feed And } \\
\text { Forage Crops } 1 /\end{array}$} \\
\hline & & $\operatorname{Corn}(G r a i n)$ & Sorghum & Wheat & & Pasture & Range & \\
\hline 1990 Model Run & N.C. & +468 & N.C. & N.C. & -28 & -168 & N.C. & -128 \\
\hline 2000 Model Run & N.C. & +398 & N.C. & N.C. & +28 & -168 & N.C. & -178 \\
\hline 2010 Model Run & N.C. & +398 & N.C. & N.C. & N.C. & -168 & N.C. & -208 \\
\hline
\end{tabular}

1/ Based on the assumption of the Department of Water Resources that applied water use per hectare (acre) will be reduced by 10 percent by 2000 .

N.C. - No change from 1978 model base run. 
PROJECTED PERCENTAGE CHANGES IN LIVESTOCK AND POULTRY PRODUCTION FROM THE 1978 MODEL BASE RUN

\begin{tabular}{l|c|c|c|c|c}
\hline & $\begin{array}{c}\text { Milk } \\
\text { Cows }\end{array}$ & $\begin{array}{c}\text { Feedlot } \\
\text { Marketings }\end{array}$ & Eggs & Broilers & Turkeys \\
\hline 1990 Model Run & N.C. & N.C. & $+17 \%$ & $+62 \%$ & $+37 \%$ \\
2000 Model Run & $-2 \%$ & $-11 \%$ & $+27 \%$ & $+98 \%$ & $+76 \%$ \\
2010 Mode1 Run & $-5 \%$ & $-13 \%$ & $+29 \%$ & $+150 \%$ & $+116 \%$ \\
\hline
\end{tabular}

N.C. - No change from the 1978 model base run.

\section{Feed Crops}

Barley and sorghum acreage are projected to remain constant over the project period (1978-2010). Wheat acreage, based on amounts used for feeding, will also remain constant. Corn will increase to 146 percent of 1976-78 levels and then decline somewhat, leveling off at 139 percent by 2000 .

\section{Forage Crops}

Projected alfalfa hay acreage decreases only two percent from 1978 to 1990. This amount is, in all likelihood, statistically insignificant. Alfalfa acreage increases slightly in 2000 and remains at 1978 levels in 2010. The demand for alfalfa hay is closely tied to dairy production. It is estimated that about 75 percent of alfalfa produced in California is consumed by dairy cows [68]. The model results indicate that most of the future hay demand will continue to be met by California production, as it was during the 1976-1978 base period. Although alfalfa is a relatively high water-using crop and despite the increases in water costs of the model, most of the demand for alfalfa will continue to be met from alfalfa produced within the state. These results indicate that, despite increasing water costs, the leastcost way to provide alfalfa hay is to continue to grow it in california rather than to ship more of it in from other states.

Irrigated pasture declines to 84 percent of the 1978 model run by 1990, then remains at this level, due to the minimum acreage constraints put into the model. This is significant in terms of water use for feed crops because pasture is a high water-using crop. The minimum irrigated pasture acreage was 
water-using crop. The minimum irrigated pasture acreage was 846 thousand acres, the amount in the model solutions. This means that, if left unconstrained, fewer acres of pasture would be predicted by the model in the projections. Since significant pasture acreages are known to be in production, the conclusion was drawn that, for this part of the model, reality is not captured well without a minimum constraint.

There are several possible reasons for needing a minimum acreage constraint. In some cow-calf and stocker operations, pasture is used seasonally to supplement dry range; cattle are moved to the pasture when the range becomes dry. These seasonal aspects of production are not addressed by the model, yet they are known to exist to some degree [44]. About 142 thousand hectares ( 350 thousand acres) of California land is used as irrigated pasture because little or no other agricultural use can be found for that particular class of land [123]. Also, there are the somewhat intangible aspects of pasture production; pasture is useful in breaking up soil and deterring soil erosion. Moreover, it is relatively hardy and requires little attention to its growth.

\section{Applied Water Use}

Given the water costs and conservation levels assumed in the model, and the declining irrigated pasture acreages projected, the use of water could be expected to decline from 1978 levels. Applied water use in 1990 is 12 percent less than in 1978 for feed uses for model feed crops (Table 7). In 2000 and 2010, applied water use declines somewhat more, to 84 and 80 percent. The change from 1978 to these years reflects the 10 percent water conservation assumption and the 20 percent decline in irrigated pasture acreage.

\section{Livestock and Poultry Production}

Milk cow projections are quite dependent on projected trends for milk production per cow. California milk production per cow has increased about 40 percent in the last 20 years [17]. There is also great potential for continued increase, because some of the top producers in the state are producing more than twice the state average [32].

The study II report [46], identified in Chapter I, projects a most likely scenario of continued milk production per cow increases, but not at the rate of the trend extrapolations of the past 20 years. A reasonable average production per cow figures would show increases from 7,030 kilograms $(15,500$ pounds) per cow in 1980 to $7,710 \mathrm{kilograms}(17,000$ pounds) per cow in 1990, 8,620 kilograms $(19,000$ pounds) per cow in 2000 , and $9,525 \mathrm{kilo-}$ grams $(21,000$ pounds) per cow in 2010. Assuming these figures, the milk consumption per capita of Chapter IV, and projected population increases from the Department of Finance [61], cow numbers are likely to be 852 thousand in 1990,833 thousand in 2000 and 810 thousand in 2010 . If production per cow increases 
more modestly, milk cow numbers would remain roughly constant. The decline could be also reversed, if California begins to ship milk to other states, but the model did not allow this activity to take place.

Beef feedlot marketing declined from 1978 to 1990 , from 1.7 to $1.2 \mathrm{million}$ head. Thereafter it drops to the minimum levels specified in the model design, about 1.1 million head.

Minimal cattle feeding production levels were chosen because cattle feeding is not subject to resource constraints, only to cost constraints. It uses very small amounts of $l$ and and water; therefore, theoretically, it is virtually unconstrained. Since models choose the least-cost method of supplying consumer demand, there is often a tendency for them to show production of all beef only at the optimal location. Institutional constraints exist that the model does not take into account. Seasonal aspects of cattle feeding are one of these. The Imperial Valley may have a cost advantage in the winter months when the rest of the United States is quite cold and cattle in that region do not easily gain weight. Fixed investment costs are another; an operator may remain in a cattle feeding operation at a given location because his fixed costs are covered, even though he could make more money in the long run in another location. The producers' assumed planning horizon is another intangible consideration; an operator with a short-run perspective may be making decisions based only at returns on variable costs, rather than fixed and variable costs. Finally, not all producers are profit-maximizers; some may be in the industry for other reasons, such as having a preference for this particular line of work.

All these factors were considered in specifying the minimum feedlot production levels. California feedlot marketings were allowed to fall only to $1,130,000$ head in 2000 and $1,105,000$ head in 2000. These were chosen on the basis of the trend lines shown in Chapter III. They were chosen only after model runs were made that did not put minimum limits on fed cattle production. These computer runs show no California production taking place, an unrealistic result in light of the above discussion.

Poultry production, as predicted by the model, generally increases as both per capita consumption and population increase. production is pretty much geared to the California market because the southeastern United States will face distance-related transportation cost disadvantages in shipping to California.

Egg production in 2010 is 1.3 times higher than in 1978; broiler production is 2.5 times higher; and turkey production is 2. 2 times higher. These are highly reflective of projected per capita consumption trends, because chicken consumption is expected to increase dramatically; turkeys, to increase somewhat; and eggs, to increase at a moderate rate. 
Water and transportation cost increases have been noted to be probably somewhat overly pessimistic. Therefore, these assumed rate increases are an upper bound.

Sensitivity analyses for variables other than energyrelated water and transportation costs were not made. Changes in feeding efficiency, crop yields, and other inputs could be done, but they were not viewed as important variables to consider in this particular study.

There were few changes in crop or livestock production from 1990 to 2010 , except for poultry and milk production, which largely reflected change in consumer tastes and population growth. The decline in cattle feeding and pasture production occurs between 1978 and 1990, indicating that a relatively small increase in transportation and water costs (up to 50 percent over 1978 in real terms) will have large impacts in the cattle feeding and raising industries. Once those adjustments occur, little change takes place, even when water costs increase 2.5 times over 1978 levels and energy costs increase 4 times over 1978 levels in 2010. This is largely due to the minimum levels specified and discussed earlier. 
California hay producers are expected to continue supplying nearly all the hay required by the State's cattle. Hay acreage should remain constant.

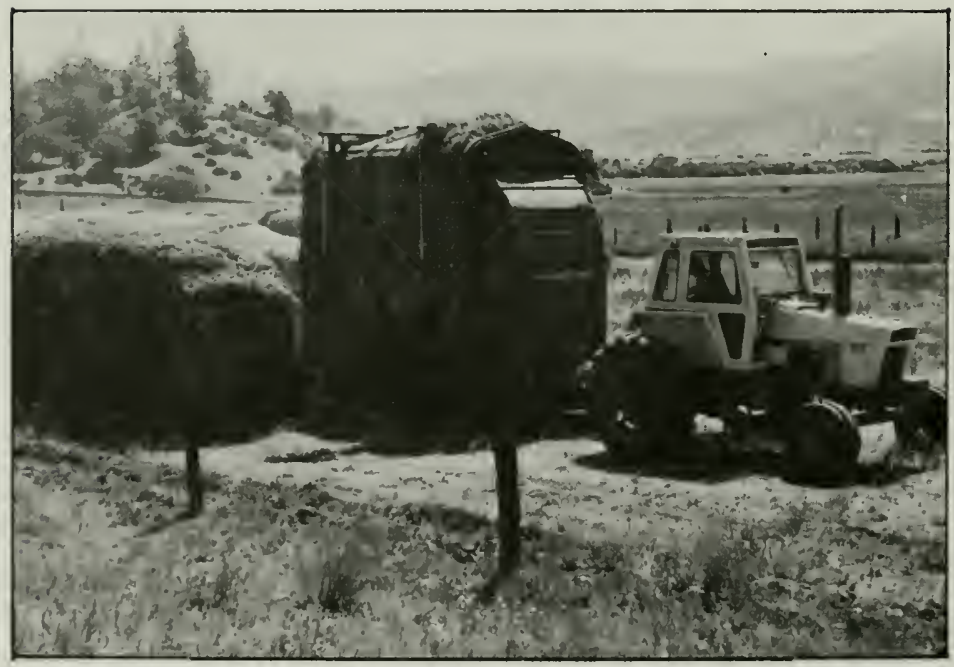


CHAPTER VI

\section{CONCLUDING ASSESSMENT OF STUDY RESULTS}

The purposes of this chapter are to:

(1) Project the applied water use associated with the livestock and poultry industries.

(2) Identify and discuss the major reasons for choosing these particular projections.

(3) Discuss the strengths and weaknesses of the projections selected and the methodologies used.

In assessing the model projections, this chapter brings together the analysis of past trends, the results of the linear programming model, the results of the independent study IIlivestock and poultry projections, and the judgment of informed persons.

Chapter III of this report analyzes trends taking place in California feed and forage crop production and livestogk and poultry production from the data developed in Study I- [68]. Chapters IV and $\mathrm{V}$ show the results of the 1 inear programming model for the base run and projections.

To project on the basis of past trends discussed in Chapter III would be extremely naive. However, to project on the basis of linear programming model results alone would be equally foolish.

1/ Studies I and II refer to the other components of the entire DWR Livestock Study, as outlined in Chapter I of this bulletin. These studies are reported in separate publications [46] and $[68]$, as referenced in the bibliography of this report. 
Therefore, taking all these points of view, a set of most 1 ikely projections (Tables 11 and 12) has been prepared and general conclusions have been drawn regarding California's future livestock and poultry production numbers and acreages devoted to feed and forage crops.

These crop acreages, which reflect the projections of future livestock and poultry production, also provide the basis for estimating quantities of applied water that will be needed to produce the crops. As shown in Table 12, except for a drop in barley of about 156 hectares $(386,000$ acres) between 1978 and 1990, acreages should remain generally about the same.

\section{Projections of Applied Water Use}

Based on the Table 12 crop projections, total applied water use for feed and forage crops used for 1 ivestock and poultry feeding is expected to decline about 10 percent from 1978 to 2010 (Table 13), or from 16236 cubic dekametres $(13,143,000$ acre-feet)

TABLE 11

CALIFORNIA LIVESTOCK AND POULTRY CONSUMPTION AND PRODUCTION PROJECTIONS

\begin{tabular}{|c|c|c|c|c|c|}
\hline Activity & Unit. & $\begin{array}{l}\text { Base } \\
\text { Period }\end{array}$ & 1990 & 2000 & 2010 \\
\hline \multicolumn{6}{|l|}{ Consumption, per capita } \\
\hline Beef and veal & $\begin{array}{l}\text { Kilograms } \\
\text { (pounds) }\end{array}$ & $\begin{array}{c}66 \\
(145)\end{array}$ & $\begin{array}{c}64 \\
(140)\end{array}$ & $\begin{array}{c}68 \\
(150)\end{array}$ & $\begin{array}{c}70 \\
(155)\end{array}$ \\
\hline $\begin{array}{l}\text { Milk (fresh equivalent } \\
\text { basis) }\end{array}$ & $\begin{array}{l}\text { Kilograms } \\
\text { (pounds) }\end{array}$ & $\begin{array}{l}249 \\
(550)\end{array}$ & $\begin{array}{c}249 \\
(550)\end{array}$ & $\begin{array}{l}245 \\
(540)\end{array}$ & $\begin{array}{r}240 \\
(530)\end{array}$ \\
\hline Chickens and turkeys & $\begin{array}{l}\text { Ki lograms } \\
\text { (pounds) }\end{array}$ & $\begin{array}{c}24 \\
(52)\end{array}$ & $\begin{array}{c}30 \\
(66)\end{array}$ & $\begin{array}{l}31 \\
(69)\end{array}$ & $\begin{array}{c}33 \\
(72)\end{array}$ \\
\hline Eggs & Millions & 297 & 285 & 285 & 285 \\
\hline \multicolumn{6}{|l|}{ Production } \\
\hline Feedlot marketings & $\begin{array}{l}\text { Thousands } \\
\text { of head }\end{array}$ & 1,400 & 1,700 & 1,700 & 1,700 \\
\hline Milk cows & $\begin{array}{l}\text { Thousands } \\
\text { of head }\end{array}$ & 846 & 850 & 830 & 810 \\
\hline Milk produced per cow & $\begin{array}{l}\text { Kilograms } \\
\text { (pounds) }\end{array}$ & $\begin{array}{cc}6 & 350 \\
(14,000)\end{array}$ & $\begin{array}{c}7710 \\
(17,000)\end{array}$ & $\begin{array}{c}8620 \\
(19,000)\end{array}$ & $\begin{array}{r}9530 \\
(21,000)\end{array}$ \\
\hline Chickens and turkeys & $\begin{array}{l}\text { Millions of } \\
\text { kilograms } \\
\text { (millions of } \\
\text { pounds) }\end{array}$ & $\begin{array}{c}318 \\
(700)\end{array}$ & $\begin{array}{c}490 \\
(1,080)\end{array}$ & $\begin{array}{c}610 \\
(1,345)\end{array}$ & $\begin{array}{r}760 \\
(1,675)\end{array}$ \\
\hline Eggs & Millions & 8,412 & 9,569 & 10,396 & 10,555 \\
\hline
\end{tabular}

1/ Base periods: Per capita consumption = 1975-1977.

Production $=1978$. 
in 1978 to 14524 cubic dekametres $(11,775,000$ acre-feet) in 2010 . These forecasts were calculated by using projected average statewide applied water use coefficients and assumed water conservation practices.

The decline in total feed and crop water use is largely due to expected improvements in irrigation technology and management. It reflects the constant pasture acreage projection discussed later in this chapter. This finding has considerable significance because 37 percent of the total water used by the feed and forage crop industry is used to produce pasture.

As discussed in greater detail later in this chapter, the model results show water use for feed and forage crops declining

\section{TABLE 12}

PRESENT AND PROJECTED FEED AND FORAGE CROPS

In thousands of hectares

(in thousands of acres)

\begin{tabular}{|c|c|c|c|c|}
\hline & 1978 & 1990 & 2000 & 2010 \\
\hline \multicolumn{5}{|l|}{ Feed Grains $1 /$} \\
\hline Barley & $\begin{array}{c}338 \\
(836)\end{array}$ & $\begin{array}{c}182 \\
(450)\end{array}$ & $\begin{array}{c}182 \\
(450)\end{array}$ & $\begin{array}{c}182 \\
(450)\end{array}$ \\
\hline Corn (grain) & $\begin{array}{c}93 \\
(231)\end{array}$ & $\begin{array}{c}114 \\
(281)\end{array}$ & $\begin{array}{l}108 \\
(268)\end{array}$ & $\begin{array}{l}108 \\
(268)\end{array}$ \\
\hline Corn (silage) & $\begin{array}{c}71 \\
(175)\end{array}$ & $\begin{array}{c}86 \\
(212)\end{array}$ & $\begin{array}{c}86 \\
(212)\end{array}$ & $\begin{array}{c}86 \\
(212)\end{array}$ \\
\hline Sorghum & $\begin{array}{c}69 \\
(170)\end{array}$ & $\begin{array}{c}64 \\
(157)\end{array}$ & $\begin{array}{c}64 \\
(157)\end{array}$ & $\begin{array}{c}64 \\
(157)\end{array}$ \\
\hline Wheat & $\begin{array}{l}23 \\
(57)\end{array}$ & $\begin{array}{c}12 \\
(30)\end{array}$ & $\begin{array}{c}12 \\
(30)\end{array}$ & $\begin{array}{c}12 \\
(30)\end{array}$ \\
\hline Total Feed Grains & $\begin{array}{c}594 \\
(1,469)\end{array}$ & $\begin{array}{c}458 \\
(1,130)\end{array}$ & $\begin{array}{r}452 \\
(1,117)\end{array}$ & $\begin{array}{r}452 \\
(1,117)\end{array}$ \\
\hline \multicolumn{5}{|l|}{$\underline{\text { Hay }}$} \\
\hline Alfalfa Hay & $\begin{array}{c}408 \\
(1,007)\end{array}$ & $\begin{array}{l}400 \\
(989)\end{array}$ & $\begin{array}{c}418 \\
(1,033)\end{array}$ & $\begin{array}{r}408 \\
(1,007)\end{array}$ \\
\hline Other Hay & $\begin{array}{l}210 \\
(520)\end{array}$ & $\begin{array}{l}210 \\
(520)\end{array}$ & $\begin{array}{c}210 \\
(520)\end{array}$ & $\begin{array}{l}210 \\
(520)\end{array}$ \\
\hline Total Hay & $\begin{array}{c}618 \\
(1,527)\end{array}$ & $\begin{array}{c}610 \\
(1,509)\end{array}$ & $\begin{array}{c}628 \\
(1,553)\end{array}$ & $\begin{array}{c}618 \\
(1,527)\end{array}$ \\
\hline Irrigated Pasture & $\begin{array}{c}393 \\
(970)\end{array}$ & $\begin{array}{c}393 \\
(970)\end{array}$ & $\begin{array}{c}393 \\
(970)\end{array}$ & $\begin{array}{c}393 \\
(970)\end{array}$ \\
\hline
\end{tabular}

1/ Portions of crops consumed for animal feed in California. 
20 percent, largely because the model showed a decrease in pasture, rather than constant pasture acreage.

\section{Projections of Livestock and Poultry Production}

Projections of selected measures of livestock and poultry production activity are shown in Table 11. Except for feedlot marketings, these projections are the same as the linear programming results shown in Table 14 . The Table 11 results, in terms of general direction, are consistent with the trend extrapolations of the same date (Table 14).

TABLE 13

APPLIED WATER USE PROJECTIONS FOR FEED AND FORAGE CROPS

In thousands of cubic dekametres

(in thousands of acre-feet)

\begin{tabular}{|c|c|c|c|c|}
\hline & 1978 & 1990 & 2000 & 2010 \\
\hline \multicolumn{5}{|l|}{ Feed Grains $1 /$} \\
\hline Barley & $\begin{array}{c}844 \\
(678)\end{array}$ & $\begin{array}{c}433 \\
(351)\end{array}$ & $\begin{array}{c}412 \\
(334)\end{array}$ & $\begin{array}{c}412 \\
(334)\end{array}$ \\
\hline Corn (grain) & $\begin{array}{c}841 \\
(682)\end{array}$ & $\begin{array}{l}1,060 \\
(859)\end{array}$ & $\begin{array}{c}950 \\
(770)\end{array}$ & $\begin{array}{c}950 \\
(770)\end{array}$ \\
\hline Corn (silage) & $\begin{array}{c}694 \\
(563)\end{array}$ & $\begin{array}{c}800 \\
(649)\end{array}$ & $\begin{array}{c}757 \\
(614)\end{array}$ & $\begin{array}{c}757 \\
(614)\end{array}$ \\
\hline Sorghum & $\begin{array}{l}524 \\
(425)\end{array}$ & $\begin{array}{c}461 \\
(374)\end{array}$ & $\begin{array}{c}435 \\
(353)\end{array}$ & $\begin{array}{l}435 \\
(353)\end{array}$ \\
\hline Wheat & $\begin{array}{l}109 \\
(88)\end{array}$ & $\begin{array}{c}54 \\
(44)\end{array}$ & $\begin{array}{l}51 \\
(41)\end{array}$ & $\begin{array}{l}51 \\
(41)\end{array}$ \\
\hline \multicolumn{5}{|l|}{ Hay and Pasture } \\
\hline Alfalfa Hay & $\begin{array}{c}6 \quad 610 \\
(5,337)\end{array}$ & $\begin{array}{c}6 \quad 610 \\
(4,994)\end{array}$ & $\begin{array}{c}6103 \\
(4,948)\end{array}$ & $\begin{array}{c}5957 \\
(4,829)\end{array}$ \\
\hline Other Hay & $\begin{array}{c}640 \\
(520)\end{array}$ & $\begin{array}{c}609 \\
(494)\end{array}$ & $\begin{array}{c}578 \\
(469)\end{array}$ & $\begin{array}{c}578 \\
(469)\end{array}$ \\
\hline Irrigated Pasture & $\begin{array}{c}5974 \\
(4,850)\end{array}$ & $\begin{array}{c}5659 \\
(4,588)\end{array}$ & $\begin{array}{l}5384 \\
(4,365)\end{array}$ & $\begin{array}{c}5384 \\
(4,365)\end{array}$ \\
\hline TOTAL & $\begin{array}{c}16236 \\
(13,143)\end{array}$ & $\begin{array}{c}15,236 \\
(12,353)\end{array}$ & $\begin{array}{c}14,670 \\
(11,894)\end{array}$ & $\begin{array}{c}14524 \\
(11,775)\end{array}$ \\
\hline
\end{tabular}

1/ Portions of crops used for animal feed. 
Beef Cattle

Feedlot marketings are projected to remain constant at the 1976-1978 level of 1,700,000 head (Table 11). This level is higher than the 1978 level because, in 1978, feedlot marketings were at one of the low-production years of the cattle cycle.

The feedlot marketing projections shown in Table 11 do not coincide with either the model results or the trend extrapolations of Table 14. Cattle feeding in California is shown in the trends and the model to be gradually declining (Table 14). The Livestock Advisory Committee members were mixed in their opinions on the future of the industry in California.

The results of Study II of the University of California [46], which vary considerably from those of the linear programming model or the trend extrapolation for California-fed beef cattle production, provide valuable insights in reaching a conclusion

TABLE 14

COMPARISONS OF THE LINEAR PROGRAMMING MODEL WITH TREND EXTRAPOLATIONS FOR CALIFORNIA PRODUCTION

\begin{tabular}{|c|c|c|c|c|c|c|c|c|c|c|}
\hline & \multicolumn{4}{|c|}{ Feed Graingl/ } & Hay & \multicolumn{2}{|c|}{ Livestock } & & \multicolumn{2}{|c|}{ Poultry } \\
\hline & \multicolumn{4}{|c|}{$\begin{array}{l}\text { In thousands of hectares } \\
\text { (thousands of acres) }\end{array}$} & \multirow{2}{*}{$\begin{array}{l}\text { Alfalfa Hay } \\
\text { In thousands } \\
\text { of hectares } \\
\text { (thousands } \\
\text { of acres }\end{array}$} & \multicolumn{2}{|c|}{ In thousands of head } & \multirow{2}{*}{$\begin{array}{l}\text { Eggs } \\
\text { In } \\
\text { mil- } \\
\text { lions }\end{array}$} & \multicolumn{2}{|c|}{$\begin{array}{l}\text { In millions } \\
\text { of kilograms } \\
\text { (millions of } \\
\text { pounds) }\end{array}$} \\
\hline & Barley & $\begin{array}{c}\text { Corn } \\
(\text { Grain })\end{array}$ & Sorghum & Wheat & & Milk Cows & $\begin{array}{l}\text { Feedlot } \\
\text { Marketings }\end{array}$ & & Broilers & Turkeys \\
\hline $\begin{array}{l}1978 \text { Reference } \\
\text { Data }\end{array}$ & $\begin{array}{c}338 \\
(836)\end{array}$ & $\begin{array}{c}93 \\
(231)\end{array}$ & $\begin{array}{c}69 \\
(170)\end{array}$ & $\begin{array}{c}23 \\
(57)\end{array}$ & $\begin{array}{c}408 \\
(1,007)\end{array}$ & 846 & 1,415 & 8,412 & $\begin{array}{c}197 \\
(431)\end{array}$ & $\begin{array}{c}122 \\
(269)\end{array}$ \\
\hline $\begin{array}{l}1978 \text { Predicted } \\
\text { Trend }\end{array}$ & $\begin{array}{c}293 \\
(724)\end{array}$ & $\begin{array}{c}106 \\
(262)\end{array}$ & $\begin{array}{c}88 \\
(217)\end{array}$ & $\begin{array}{c}32 \\
(79)\end{array}$ & $\begin{array}{c}463 \\
(1,144)\end{array}$ & 791 & 1,736 & 8,982 & $\begin{array}{c}152 \\
(335)\end{array}$ & $\begin{array}{c}117 \\
(258)\end{array}$ \\
\hline $1990 \mathrm{Tr}$ end & $\begin{array}{c}104 \\
(257)\end{array}$ & $\begin{array}{c}161 \\
(398)\end{array}$ & $\begin{array}{c}63 \\
(156)\end{array}$ & $\begin{array}{c}43 \\
(106)\end{array}$ & $\begin{array}{c}456 \\
(1,127)\end{array}$ & 799 & 1,504 & 10,435 & $\begin{array}{c}219 \\
(482)\end{array}$ & $\begin{array}{c}118 \\
(260)\end{array}$ \\
\hline 1990 Model & $\begin{array}{c}182 \\
(450)\end{array}$ & $\begin{array}{c}114 \\
(281)\end{array}$ & $\begin{array}{c}64 \\
(157)\end{array}$ & $\begin{array}{c}12 \\
(30)\end{array}$ & $\begin{array}{c}400 \\
(989)\end{array}$ & 852 & 1,275 & 9,569 & $\begin{array}{l}310 \\
(682)\end{array}$ & $\begin{array}{c}178 \\
(393)\end{array}$ \\
\hline 2000 Trend & $\begin{array}{c}85 \\
(210)\end{array}$ & $\begin{array}{l}165 \\
(408)\end{array}$ & $\begin{array}{c}50 \\
(124)\end{array}$ & $\begin{array}{c}55 \\
(136)\end{array}$ & $\begin{array}{c}451 \\
(1,114)\end{array}$ & 805 & 1,302 & 11,645 & $\begin{array}{l}261 \\
(575)\end{array}$ & $\begin{array}{c}113 \\
(250)\end{array}$ \\
\hline 2000 Model & $\begin{array}{c}182 \\
(450)\end{array}$ & $\begin{array}{c}108 \\
(268)\end{array}$ & $\begin{array}{c}64 \\
(157)\end{array}$ & $\begin{array}{c}12 \\
(30)\end{array}$ & $\begin{array}{c}418 \\
(1,033)\end{array}$ & 833 & 1,130 & 10,396 & $\begin{array}{c}379 \\
(835)\end{array}$ & $\begin{array}{l}230 \\
(506)\end{array}$ \\
\hline 2010 Trend & $\begin{array}{c}68 \\
(168)\end{array}$ & $\begin{array}{c}173 \\
(427)\end{array}$ & $\begin{array}{c}37 \\
(91)\end{array}$ & $\begin{array}{c}66 \\
(163)\end{array}$ & $\begin{array}{c}446 \\
(1,101)\end{array}$ & 811 & 1,100 & 12,856 & $\begin{array}{c}329 \\
(726)\end{array}$ & $\begin{array}{c}118 \\
(260)\end{array}$ \\
\hline 2010 Mode I & $\begin{array}{c}182 \\
(450)\end{array}$ & $\begin{array}{c}108 \\
(268)\end{array}$ & $\begin{array}{c}64 \\
(157)\end{array}$ & $\begin{array}{c}12 \\
(30)\end{array}$ & $\begin{array}{c}408 \\
(1,007)\end{array}$ & 810 & 1,105 & 10,555 & $\begin{array}{c}478 \\
(1054)\end{array}$ & $\begin{array}{l}281 \\
(620)\end{array}$ \\
\hline
\end{tabular}

1/ Areas for portions of crops used for feed. 
regarding the most likely California cattle feeding scenario. The University of California foresees a future in which rising transportation costs, reflecting rising energy costs, will mean more California beef cattle will be raised and fed in California than will be shipped to other states for feeding, as currently is the case for most California stocker cattle [46]. This scenario is a most likely future. Under these conditions, the study II results show feedlot marketings of about $1,900,000$ by 2000 .

The DWR linear programming model, which took a less detailed look at the industry, projected 1,100,000 head for 2000 (Table 14). The consensus projection is weighted heavily toward the study II results. What we would expect to be most likely to occur is that feedlot marketings in 2010 will remain roughly similar to 1976-1978 levels of about 1,700,000 head (Table 11). These results have great importance for future land and water use projections and will be discussed later in this chapter.

\section{Dairy Cattle}

Milk cow inventory numbers are projected to increase slightly from 1978 to 1990, and then decline slightly thereafter, settling in 2010 at 810,000 head, below the 1978 level of 846,000 head. Total milk production will continue to expand because milk production per cow is expected to continue to increase. California will continue to be self-sufficient in meeting its fluid milk demands. Our most likely scenario indicates a slight decrease in per capita consumption of all milk products

(Table 11), but a slight increase in total production and consumption because of population growth. The rate of increase implied by this scenario is slower than trends indicate has occurred in the past 20 years.

Some members of the Advisory Committee have a slightly different view. They believe that per capita milk consumption will hold constant or increase slightly, and uses will shift from fluid to nonfluid as consumption of cheese begins to exceed that of fluid milk. Members close to the dairy industry also expressed the opinion that, with a favorable climate and large economic production units, California milk production will continue to expand at a rate closer to that of the recent past. As a result, they felt, California will be taking less cheese from other states and consuming more cheese produced by California dairies. Cheese will also be shipped to other states [31].

Since 1970 , milk cow numbers and milk production per cow have both increased in California (Figure 9, Chapter III). These changes lend support to these Advisory Committee members' views. However, what will actually happen cannot be easily predicted because possible changes in the current institutional structure of federal and state marketing orders could have a strong effect on these projections. 
The linear programming model, past trends, and the Advisory Committee agree that the outlook for California chicken and turkey production is reasonably bright. The most likely production projections, shown in Table 11 , reflect this view. These show both a per capita increase in consumption -- 24 kilograms ( 52 pounds) in 1975-77 to $33 \mathrm{kilograms} \mathrm{(72} \mathrm{pounds)} \mathrm{in} \mathrm{2010;} \mathrm{and} \mathrm{a}$ significant increase in total production from $318 \mathrm{million}$ kilograms ( $700 \mathrm{million}$ pounds) in 1978 to $760 \mathrm{mill}$ ion kilograms $(1,675$ million pounds) in 2010 .

The Advisory Committee felt that changing consumer tastes, as evidenced by increased retail sales of chicken and turkey, plus the growing use of turkey and chicken in processed foods, signal higher per capita consumption and hence a larger market for these types of meat.

California ships in large quantities of the chicken and turkey consumed in the state. Because california is a deficit poultry meat producer, the State's market offers much room for expansion. California producers can be expected to supply a larger portion of the home demand. California's favorably mild climate and great distance from major competitors in the southeastern United States strengthen the State's competitive position with respect to other producing regions of the nation.

Dr. Cothern's findings in Study II indicate that combined transportation and production costs are likely to remain lower for California poultry producers than for southeastern export producers. Most Advisory Committee members believe that California producers will maintain a strong competitive position in the future.

Total California egg production is also expected to increase (Table 14). California per capita egg consumption is projected to decrease slightly but, because population is growing, total egg consumption will increase. The state is a selfsufficient egg producer and ships a relatively small percentage of its output to other states.

Projections of California egg production from trend extrapolation and the linear programming model take the same general direction, but the trend extrapolations are higher. The Study II projections are much lower than the trend extrapolation and slightly lower than the model results. Therefore, the model results would appear to strike a reasonable middle ground. The Advisory Committee had no major disagreement with this position. 
Feed crop acreage projections deal only with the portion of the total acreage consumed in California as animal feed. Barley is projected to drop by 156000 hectares $(386,000$ acres ) by 1990. Except for this decrease, total feed grain acreages are expected to stay at about 450000 hectares (about 1,000,000 acres) through 2010, with small increases in corn, both grain and silage, and small decreases in sorghum and wheat (Table 12).

All these projections are taken directly from the model results. The model did not consider crops other than those produced for feed and forage. In reality, however, other crops do compete for land used for feed and forage production. Therefore, the projections presented here should be viewed as an upper bound because other crops not considered in this study are likely to occupy some of the acreage devoted to these crops.

Future California livestock and poultry production will affect the feed grain crop industry, although perhaps not as much as one might expect. California producers currently ship in about half the feed grains fed to livestock and poultry, and this percentage is likely to increase.

Past total acreage trends show barley decreasing, sorghum decreasing slightly, and corn and wheat increasing. Except for wheat acreage, the model results follow the same direction as the trends. Since less than 10 percent of California-grown wheat is used for feeding, total wheat for feeding may not necessarily follow total wheat acreage trends.

Nevertheless, these projections may easily change direction, and one should look at some of the reasons why this may occur. For example, the possibility exists that barley acreage will increase, rather than remain constant or decrease. The increasing salinity problems of the San Joaquin Valley, coupled with the likelihood of using saline drainage water for crop production, could possibly bring this about. Barley varieties have been developed that can tolerate high levels of salinity reasonably well $[81,90]$, and some of this saline water could be used to produce barley and other salt-tolerant crops [90]. Saline drainage water should be relatively less expensive than fresh water, particularly as pumping costs increase in the future. Although the possibility of increasing barley acreage with the use of saline water cannot be substantiated at present, it is worth bearing in mind as another qualitative factor in making long-term projections of feed and forage crop acreages.

Other factors would also affect the future of corn and wheat acreages. Corn could increase even more than is projected 
because of its potential nonfeed uses as a sweetener and in gasohol production [40]. California corn and wheat production may also exceed the results shown by the model because of California's proximity to new grain markets developing in China and Japan [44].

\section{Hay Production}

Both alfalfa and other types of hay acreage are projected to be very close to 1978 levels in the future -- about 618000 hectares (about 1,530,000 acres) (Table 12). Alfalfa hay acreage is geographically tied to livestock production and dairies because it is very expensive to ship the hay long distances. The model shows that alfalfa acreage will change by very small amounts (Table 12). This is also demonstrated by the trend extrapolation ( Table 14).

Irrigated Pasture and Rangeland

Irrigated pasture is expected to remain at the 1978 level of 393000 hectares $(970,000$ acres) (Table 12).

One of the larger discrepancies between the model results and the findings of Study II, as noted earlier in this chapter, concerns the projections of fed cattle marketings. The linear programming model shows a 20-percent decline in irrigated pasture acreage from 1976-78 levels, a result that conflicts with the implications of the Study II results.

Study II indicates that beef cattle inventories are likely to increase from 869,000 head in 1980 to $1,050,000$ head in 2000 [46]. Inventories in 1975-77 were close to that figure with 1,032,000 head. If current levels of beef cattle inventories are to be maintained in 2010 (a conservative estimate in light of Study II results), one would expect irrigated pasture acreage to also remain constant, if pasture productivity shows no gain.

The Study II findings are predicated largely on the condition that cattle born and raised in California remain in California for feeding. In this set of circumstances, the most likely scenario would unfold as follows: California cattle raised on pasture or range until ready to enter feedlots (stocker cattle) will continue to decline in value for the next few years, in relation to their Rocky Mountain counterparts. This gap in value will encourage more local California purchase and feeding of these animals. This development will eventually cause some modernization and expansion of existing California facilities. Also, more closely controlled and coordinated types of feeding and processing linkages will develop. If this scenario takes place, more fed cattle will be marketed in California.

If, as the Study II results indicate, large numbers of cattle remain in California for feeding, they could significantly 
affect irrigated pasture and rangeland acreage. Beef cattle currently consume about 73 percent of the total animal unit month production of California range and pasture (excluding amounts consumed by horses). Dairy cows consume another 17 percent, and sheep, the remainder [68]. As discussed previously, the dairy industry is likely to remain constant in numbers of cows. With pasture use per cow by the dairy industry at historically low levels and with few economic incentives to change these production practices, pasture use by dairy cows will probably remain constant. California sheep production is also not expected to increase dramatically [46]. Therefore, changes in beef cattle inventories are likely to have very important consequences for irrigated pasture acreage.

Trends in irrigated pasture, though sketchy, can shed some additional light on the pasture situation. Study $I$, which compared 1961-1965 and 1974-1976 feeding practices, shows a 7-percent decline in animal unit months provided by irrigated pasture and rangeland (excluding pasture and range that horses consume). However, since pasture and rangeland productivity and acreage are so difficult to estimate, we have no reliable way of knowing whether this reduction occurs on dry rangeland or irrigated pasture. From land use surveys, the Department of Water Resources has estimated irrigated pasture at 615000 hectares $(1,521,000$ acres) in 1965, 518000 hectares $(1,280,000$ acres) in 1972 [30], and 393000 hectares $(970,000$ acres) in 1978. This represents a 36-percent decline in irrigated pasture acreage from 1965 to 1978 .

Study I indicates that pasture acreage has declined. Range and pasture productivity has not increased in recent years and may not increase much in the future. Therefore, given constant range and pasture productivity, there are two ways to look at future pasture acreage: accept the downward trends and model results, or, consider the beef industry interrelationships studied in detail in study II that imply no decrease in pasture acreage.

There are several good reasons for projecting constant pasture acreages for the future (Table 12). First, this is a compromise between past trends in pasture acreage and Study II, which considers the future of the cattle industry in a world of scarcer resources and increasing real energy costs. Second, as discussed in Chapter III, most irrigated pasture is grown with relatively inexpensive water in areas where water costs are not likely to increase much in real terms because surface water is not pumped long distances and because the ground water table is relatively near the surface. Therefore, the water cost increases in the model for these areas are probably high since they are based on the premise of increasing energy costs. Also, many acres used to grow pasture in these areas are not suited to the culture of very many alternative crops (Chapter IV).

This pasture projection might change, if increases in rangeland productivity are considered, because rangeland can often substitute for pasture. Studies indicate that California's 
rangeland has great potential for increased productivity, if prescribed vegetative burning practices are adopted. If such practices are used widely [129], rangeland productivity could theoretically improve by as much as 4 million animal unit months in 20 years. This is a gain of almost 30 percent over current rangeland production. However, these estimates must be used cautiously; such increases have not been determined with a great degree of accuracy because this type of burning has not been used widely in recent times. Also, there are environmental concerns; if the burning is not done properly, much soil erosion can result.

The California Legislature has passed a bill that provides for partial state funding of vegetative management programs, and several pilot projects have been set up. If these projects are successful and funding continues, use of prescribed burning might expand. Effects of this practice on the California livestock industry will depend on location, area burned, and portion grazed. Thus, the increase in animal unit months is very difficult to judge at this time. Also, it will take about 20 years for the proposed program to reach maximum acreage treated. This means that most of the increase in productivity will not occur until after 2000 -- probably nearer 2010, which is beyond the period considered in this study.

\section{Factors to Consider in Making Future Studies}

Several factors relating to data and methodology presented certain difficulties during this study. These are discussed here as important areas for consideration when studies of this type are undertaken in the future.

One of the main disadvantages was a persistent lack of data. Too little is known of crop and livestock production costs and their range of variability from one producer to the next. Also, certain categories of important data are not collected and must be inferred. For example, how much grain in California is used as feed and how much is used for milling or other human and industrial consumption uses?

Even with better data, there are great difficulties in mathematically modeling the industry and projecting the future. One reason is the very complex nature of the relationships among feed and forage crops, livestock, poultry, transportation, processing, and marketing. Cattle are entering and leaving California at various stages of their life cycle and at varying degrees of completed processing.

To keep the size of the model at a reasonable level, several assumptions had to be made. One of these dealt with minimum and maximum crop acreage. This type of information is critical because the model showed that only the minimum levels of rotational crop acreage are produced in many regions for most of the projections. Differently specified minimums will give different model results. 
Related to the crop rotation problem is the fact that the model does not include the opportunity to grow crops other than feed and forage crops. The rational farmer chooses to grow the crops that are likely to provide the best return. If growing conditions are suitable and a market exists for higher value crops, a farmer will probably grow those crops. There are many crop production activities of higher value than feed and forage crops. The model does not adequately address options to grow these higher value crops.

Mathematical model studies being conducted for a forthcoming DWR report (Bulletin 160-82) will consider many more crop possibilities than those related to livestock and poultry. The model used in this report could not do this because it specified mathematically the complex feed and forage crop and livestock and poultry interrelationships discussed earlier, and these and all other types of crop production options could not be considered in the scope of this study.

Other shortcomings of the model include its highly geographically aggregated nature and its reliance on a single set of crop budgets and water costs by region. The model results are also weakened because some producers may not be profit maximizers and because production decisions may be influenced by noneconomic forces such as an individual's desire to live in the country.

To make projections, the model relied on fixed technical coefficients and was restricted to crops currently in production. (Many committee members mentioned that input substitution, especially for energy-related inputs, should be examined.) Greater water conservation than estimated is also possible to some extent, at the expense of reduced yields. How much input substitution will take place in the future and what new technological developments will occur is very difficult to assess now. Another unknown at the present time is which other crops (energy-producing crops such as jojoba, for example) may be produced as rotational substitutions for traditional feed and forage crops.

The present study is not without its strengths, however. One of the major strong points is the balance of approaches that were taken: the use of trends, mathematical modeling, cost of production analysis, and expert opinion. Comparisons among these have generally tended to point in the same direction as most of the projections, and have provided a basis for compromise where they have not. To permit consideration of new technological developments, these projections must be continually updated, again with reliance on a balance of several approaches and the expertise of individuals with varying backgrounds. 
1. Alt, Klaus. Agricultural Economist, U. S. Department of Agriculture. Economics, Statistics and Cooperative Service. Iowa State University. Ames, Iowa. (Personal Communication). February, 1979.

2. Ascher, W. Forecasting: An Appraisal for Policymakers and Planners. The Johns Hopkins University Press. Baltimore. 1978.

3. Australian Bureau of Agricultural Economics. An Econometric Model of the United States Beef Market. Beef Research Report No. 20. Canberra, Australia. May 1977 .

4. Bath, D. L., and Bennett, L. F. Maximizing Income Above Feed Costs: A Computerized Dairy Ration Program. University of California. Division of Agricultural Sciences. 1975.

5. Berry, S. L., Spurlock, G. M., Alpaugh, R., Dunbar, J. R., and Ufford, G. R. More Grass and Less Grain in Beef Production in California. University of California. Division of Agricultural Sciences. Bulletin 1873. September, 1975.

6. Bookman-Edmonston Engineering, Inc. Water Resources Management in the Southern San Joaquin Valley, California: A study of the Physical and Institutional Management Practices for Surface and Ground Water Utilization. A Report to the San Joaquin Valley Agricultural water Committee. January 1979.

7. Brewster, L. and Jacobson, M. F. The Changing American Diet. Center for Science in the Public Interest. Washington, D.C. 1978.

8. Bywater, A. C. Animal Scientist, University of California Animal Science Department. (Personal Communication). February 1979 .

9. California-Arizona Farm Press. "Less Irrigation on Sugar Beets Not Harmful". Vol. 2, No. 4. January 26, 1980 .

10. California Cattleman. Vol. 63, No. 4. Sacramento. February 1980 .

11. California County Agricultural Commissioners. 1972-1978 Agricultural Commissioner's Reports. (Various, by county). Sacramento. 
12. California Department of Finance, Financial Research Section. "California statistical Abstract".

Sacramento. 1978.

13. California Department of Food and Agriculture, California Crop and Livestock Reporting Service. "California Field Crop Review". Sacramento. January 1980.

14. January $\frac{\text { California Livestock Review. Sacramento. }}{1980 .}$

15. $\frac{\text { California Livestock Statistics, } 1978}{\text { Sacramento. June } 1979 .}$

16.

- Dairy Industry Statistics, 1978: Manufactured Dairy Products, Milk Projection, Utilization and Prices. Sacramento. 1979.

17. - Exports of Agricultural Commodities Produced in California. Sacramento (Various years).

18. - Field Crop Statistics, California: 1977-1978.

19. - Production and Marketing: Eggs, Chickens and Turkeys, California-1979. Sacramento. June 1979.

20. California Department of Food and Agriculture,

Federal-State Marketing Service. Feedstuff Prices in California, 1978. Sacramento. July 1979.

21. Grain: California Market Summary, 1978. Fresno, California. June 1979.

22. California Department of Water Resources. Advisory Panel on Agricultural Water Conservation (May, 1979): Report of Findings. Sacramento. 1979.

23. The California state Water Project - 1978 Activities and Future Management Plans. Bullet in 132-79. Sacramento. November 1979 .

24. The California water Plan: Outlook in 1974 . Bulletin 160-74. November 1974 .

25. Central District. National Agricultural Market Study. Sacramento. August 1974.

26. Central District. A Profile of California Agriculture. Sacramento. April 1974 . 
27. Division of $\mathrm{Pl}$ anning. Water Utilization Section. Acreage and Production of Nonirrigated Grazing Lands in California, 1973. November 1979.

28. of Reclamation Supplied Water. N. Sturm, DWR Consultant. Memorandum to $W$. Cole, DWR Statewide Planning Branch. Sacramento. September 12, 1979.

29. - Division of Planning, Statewide Planning Branch. Livestock and Poultry Feed Crop Study Pre-Study Interviews (April-May, 1978). C. M. Warner and R. M. Ernst. July 1978 .

30. Division of Planning, Statewide Planning Branch. Memorandum Report: Crop Market Outlook Study. Sacramento. June 4, 1975.

31. Livestock and Poultry Feed and Forage Crop Study Advisory Committee. Answers to Questionnaire: Critical Questions Requiring Committee Response. July 1979 .

32. Livestock and Poultry Feed and Forage Crop Study Advisory Committee. Minutes of meeting held November 8,1979 , at the University of California, Davis. November $30,1979$.

33. - Measuring Economic Impacts: The Application of Input-Output Analysis to California Water Resources Problems. Bulletin 210. May 1980.

34 .

Resource Evaluation office. Feed and Forage Crop Projections: Review and Analysis. by K. M. Turner. Office Report (typewritten). May 19, 1977.

35. San Joaquin District. Post-Project Economic Impact, San Joaquin Valley Service Area, 1978. Memorandum Report. Fresno, California. September 28, 1979.

36.

"State of California Estimate and Projections of County Populations, 1975-2020, Series E-150,000 and COG". (Typewritten). August 1, 1978.

37. "Vegetative Water Use in California, 1974". Bulletin 113-3. April 1975.

38. "Water Conservation in California". Bulletin 198. May 1976. 
39. California Energy Commission. California Energy Demand: 1978-2000: A Preliminary Assessment. (Staff Draft Report). August 1979 .

40. Carman, H. F. and Thor, P. K. High Fructose Corn Sweeteners: Economic Aspects of a Sugar Substitute.

University of California, Davis. Division of Agricultural Sciences. Giannini Foundation of Agricultural Economics. Bulletin 1894. July 1979.

41. Carman, H. F. California's Competitive Position in Cattle Feeding and Poultry Production: A Review of Interregional Competition Studies. University of California. Cooperative Extension Service, Agricultural Experiment Station, Giannini Foundation of Agricultural Economics. No. 72-1. October 1972.

42. Christensen, D. A. Research Assistant, Iowa State University. Center for Agricultural and Rural Development. (Personal Communication). August 1979.

43. Clawson, M. America's Land and Its Uses. The Johns Hopkins Press. Baltimore. 1972.

44. Cothern, J. H., Agricultural Economist, Unversity of California Cooperative Extension Service. (Personal Communication). January $25,1980$.

45. Beef Cattle Economics Series: Costs of Transporting Boxed and Carcass Beef, California, 1976. University of California. Division of Agricultural Sciences. Leaflet 21039. August 1978.

46. Cothern, J. H., and Gray, C. W., Horel, L., Highstreet, A., Innes, K., Kleffer, P. The Economics of Interrelated Industries: The Future of the Livestock Industry in California. Draft typewritten report. University of California. Cooperative Extension Service. 1980.

47. Cothern, J. H. Processing, Transporting and Pricing California Alfalfa Hay. University of California. Division of Agricultural Sciences. Leaflet 2890. May 1976 .

48. Day, R. H. "On Economic Optimization: A Nontechnical Survey" A Survey of Agricultural Economics Literature, Volume 2: Quantitative Methods in Agricultural Economics, 1940 s to 1970s. Edited by L. R. Martin. The University of Minnesota Press. Minneapolis. 1977. 
49. Dean, G. W., King, G. A., Carter, H. O. and Shumway, C. R. Projections of California Agriculture to 1980 and 2000. University of California. Division of Agricultural Sciences. Bulletin 847. September 1970.

50. Development and Resources Corporation. A Perspective on Flood protection of Agricultural Lands. (Typewritten report submitted to the Institute for Water Resources, U. S. Army Corps of Engineers, Fort Belvoir, Virginia). January 1976.

51. Dietrich, R. A. Interregional Competition in the Cattle Feeding Economy with Special Emphasis on Economics of Size. Texas $A$ and $M$ University. Texas Agricultural Experiment Station. Bulletin B-1115. September 1971.

52. Durrenberger, R. W. Patterns on the Land: Geographical Historical and political Maps of California. Fourth edition. National Press Books. Palo Alto,

California. (No date).

53. Dvoskin, D., Heady, E. O., and English, B. C. Energy Use in U. S. Agriculture: An Evaluation of National and Regional Impacts from Alternative Energy Policies. Iowa State University. Center for Agricultural and Rural Development. Report 78. Ames, Iowa. March 1978.

54. Dvoskin, D., and Heady, E. O. U. S. Agricultural Production Under Limited Energy Supplies, High Energy Prices, and Expanding Agricultural Exports. Iowa State University. Center for Agricultural and Rural Development. Report 69. Ames, Iowa. November 1976.

55. Ensminger, M. E. "What's Ahead for Beef Producers?" Farmer's Digest. Vol. 43, No. 4. October 1979.

56. Fereres, E., Meyer, J. L., Aljibury, F. K., Schulbach, H., Marsh, A. W., and Reed, A. D. Irrigation Costs. University of California. Division of Agricultural Sciences. Leaflet 2875. August 1978 .

57. Glenn, B. "Water Conservation Opportunities on Federal Irrigation Projects". Reclamation Era. Vol. 65, No. 2. 1979.

58. Goodman, C., and Yeary, E. A. "1978 Preliminary Budgets for the California Agricultural Resources Model". (Handwritten). December 1979. 
59. Grosson, P. D., and Frederick, K. D. The World Food

Situation: Resource and Environmental Issues in the Developing Countries and the United States. Research Paper R-6. Resources for the Future. Washington, D.C. 1977.

60. Heath, M. E., Metcalfe, D. S., and Barnes, R. F. Eorages. Third edition. Ames, Iowa. 1973.

61. Hambright, Marla. Economist, California Department of Water Resources. (Personal communication).

62. Highstreet, A., Nuckton, C. F. and Horner, G. L. Agricultural Water Use and Costs in California. University of California. Division of Agricultural Sciences, Giannini Foundation of Agricultural Economics. Bulletin 1896. July 1980.

63. Irrigation Journal. "Irrigation Survey". Vol. 29, No. 6. December 1979 .

64. Jones, T. Federal-State Market News Service, Stockton, California. (Personal communications). December 1979.

65. Kelso, M. M., Martin, W. E. and Mack, L. E. Water Supplies and Economic Growth in an Arid Environment: An Arizona Case Study. The University of Arizona Press. Tucson, Arizona. 1973.

66. Kern County Water Agency. Water Management in Kern County - A Compilation of Papers on Water Issues as of March 30,1979. Bakersfield, California. 1979.

67. King, G. A., Carter, H. O., and Dudek, D. J. Projections of California Crop and Livestock Production to 1985. University of California. Cooperative Extension Service. Agricultural Experiment Station. Giannini Foundation of Agricultural Economics. No. 77-3. May 1977.

68. King, G. A., Eitz, J. C., Warner, C. M., and Bywater, A. C. Trends in California Livestock and Poultry,

Consumption and Feed Use: 1961-1978. University of California, Davis. Division of Agricultural Sciences. Giannini Foundation of Agricultural Economics. Bulletin 1899. November, 1980.

69. Martin, M. V., and Dahl, R. P. Social Costs of Regulating Railroad' Grain Rates in the Upper Midwest. University of Minnesota. Agricultural Experiment Station. Technical Bulletin 319-1979. 1979. 
70. Matulich, S. C., and Carman, H. F. Cost-Size Relationships for Large-Scale Dairies with Emphasis on Waste Management. University of California. California

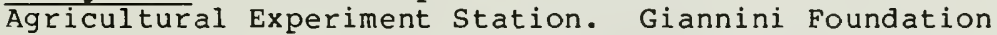
of Agricultural Economics. Research Report No. 324. October 1977 .

71. McClellan, W. D. "Project Measures Waste Water Effects on Cotton". California-Arizona Farm Press. May 26, 1979.

72. McClellan, W. D. "Report Delves into Competition for Food Between Humans and Animals". California-Arizona Farm Press. Vol. 2, No. 12. March 22, 1980.

73. McConkey, L. "Farming Trends for the 1980s". Farmers's Digest. Vol. 43, No. 4. October 1979.

74. Meister, A. D., and Nicol, K. J. A Documentation of the National Water Assessment Model of Regional Agricultural production, Land and Water Use, and Environmental Interaction. Iowa State University. Center for Agricultural and Rural Development. Miscellaneous report. December 1975 .

75. Meister, A. D., Heady, E. O., Nicol, K. J., and Strohbehn, R. W. U. S. Agricultural Production in Relation to

Alternative Water, Environmental, and Export

Policies. Iowa State University. Center for

Agricultural and Rural Development. Report 65. Ames, Iowa. June 1976.

76. Miller, R. F., Dunbar, J. R., and Berry, S. A Practical Guide to Swine Nutrition. University of California. Division of Agricultural Sciences. Leaflet 2342. December 1977 .

77. Milligan, R. A. An Economic Analysis of the Factors Affecting the California Dairy Industry. University of California. California Agricultural Experiment Station. Giannini Foundation of Agricultural

Economics. Research Report No. 325. February 1978.

78. Moore, C. V. Agricultural Economist, U. S. Department of Agriculture. Economics, Statistics and Cooperatives Service. Davis, California. (Personal Communication). March 1980.

79. Moulton, K. S. "Outlook and Issues for California Agriculture". Paper presented at the Annual Economic Outlook Conference, University of California, Davis, California. July 13, 1979. Typewritten. 
80. Pimentel, D., Oltenacu, P. A., Nesheim, M. C., Krummel, J., Allen, M. S., and Chick, S. "The Potential for Grass-Fed Livestock: Resource Constraints". Science. February 22, 1980 .

81. Porteous, H. "A Step Closer to Growing With Saline Water". California Farmer. March 1, 1980.

82. Raguse, C. A., Berry, L. J., and Street, J. E. Irrigated Pastures in California. University of California. Division of Agricultural Sciences. California Agricultural Experiment Station Extension Service. Cj.rcular 545. November 1967.

83. Rand-McNally. 1979 Road Atlas: United States, Canada, Mexico. 1979 .

84. Reed, A. D., and Horel, L. A. Beef-Planning Profitable Production. University of California, Division of Agricultural Sciences. Leaflet 2320. April 1977.

85. Reed, A. D. The Contribution of Range to the Economy of California. University of California. Cooperative Extension. Davis, California. May 1974.

86. Sawyer, Glenn. Chief, Water Conservation and Use Section, California Department of Water Resources. (Personal communication.)

87. Short, Cameron. Research Associate, Iowa State University Center for Agricultural and Rural Development. (Personal Communication). September 1979.

88. Stewart, J. I. Irrigation in California: A Report to the State water Resources Control Board. University of California, Davis. Water Science and Engineering Section, Department of Land, Air and Water Resources. June 1975.

89. Tsao, A. H. "Spatial Equilibrium and Regional Comparative Advantage in American Agriculture". Iowa State University. (Unpublished Ph.D. dissertation). Ames, Iowa. 1973.

90. Turner, K., Associate Engineer, Office of Water Conservation, California Department of Water Resources. (Personal Communication). March 1980.

91. Turner, M. S., and Atwood, J. Trucking Grain? What Does It Cost? University of Nebraska, Lincoln. Agricultural Experiment Station. Institute of Agricultural and Natural Resources. Report No. 94. March 1979. 
92. U. S. Department of Agriculture. Agricultural Statistics. Washington, D. C. 1978.

93. Another Revolution in U. S. Farming? L. P. Schert $z$ and others. Washington, D. C. 1979.

94.

1979 Handbook of Agricultural Charts.

Agriculture Handbook No. 561. Washington, D. C. october, 1979.

95.

Economic Research Service. Agriculture: The Third Century -- Commodity Production and Utilization Projections to 1985. A. G. Smith. Washington, D. C. July 1976.

96.

Economic Research Service. Cattle Feeding in the United States. R. A. Gustafson and R. N. Van Arsdall. Agricultural Economic Report No. 186. Washington, D. C. October 1970.

97. Economic Research Service. Cattle Raising in the United States. R. N. Van Arsdall and M. D. Skold. Agricultural Economic Report No. 235. Washington, D. C. January 1973.

98. Economics, statistics and Cooperatives Service. Adjustment Potential in U. S. Agriculture. Vol. 1. Scenario, Production, Price and Income Projections to 1985, 1990 and 2000 L. Quance and others. National Economic Analysis Division. (Working materials). Washington, D. C. No date.

99.

- Economics, Statistics and Cooperatives Alternative Futures for world Food in 1985. World GoL Model Analytical Report. Foreign Agricultural Service. Agricultural Economic Report No. 146. Washington, D. C. April 1978.

100. - Economics, Statistics, and Cooperatives Service. Costs of Producing Fed Cattle in the United states Final 1977, Preliminary 1978, and Projections for 1979. Washington, D. C. August 1979.

101. Economics, Statistics, and Cooperatives Service. Costs of Producing Feeder Cattle in the United States - Final 1977, Preliminary 1978, and Projections for 1979. Washington, D. C. August 1979.

102. - Economics, Statistics and Cooperatives Service. Costs of Producing Selected Crops in the United States - 1977, 1978 and Projections for 1979. Washington, D. C. June 1979 . 
103.

Economics, Statistics and Cooperatives Service. Economic Performance in Trucking of Livestock. P. N. Boles. Washington, D. C. 1977.

104.

Economics, Statistics and Cooperatives Service. Food Consumption, Price, and Expenditures. Supplement for 1976 to Agricultural Economic Report No. 138. Washington, D. C. March 1978.

105. - Economics, Statistics and Cooperatives Service. Livestock and Meat Statistics. Washington, D. C. (Various years).

106. Economics, Statistics and Cooperatives Service. Major Uses of Land in the United States: 1974. H. T. Frey. Agricultural Economic Report No. 440.

Washington D. C. November 1979.

107. Economics, Statistics and Cooperatives Service. National Food Review. Washington, D. C. (Various years).

108. Economics, Statistics and Cooperatives Service. A Perspective on Cropland Availability. L. K. Lee. Agricultural Economic Report No. 406. Washington, D. C. July 1978 .

109. Economics, Statistics and Cooperatives Service. Perspective for Productivity Growth in U. S.

Agriculture. L. Yoo-Chi, P. Cline, and L. Quance. Agricultural Economic Report No. 435. Washington, D. C. September 1979.

110. U. S. Department of Commerce. Bureau of the Census. Number of Inhabitants: United States Summary. Washington, D. C. December 1971.

111. - Bureau of the Census. Statistical Abstract of the United States, 1978. Washington, D. C. 1979.

112. Domestic and International Business Administration. U. S. Industrial Outlook, 1978, with Projections to 1985. Washington, D. C. 1978.

113. Industry and Trade Administration. 1979 U. S. Industrial Outlook with Projections to $198 \overline{3 \text { for } 200}$ Industries. Washington, D. C. January 1979.

114. U. S. Department of the Interior. Bureau of Reclamation. 1977 Federal Reclamation Projects: Water and Land Resources Accomplishments, Statistical Appendix I. washington, D. C. 1978. 
115. U. S. Department of Labor. Bureau of Labor Statistics. Monthly Labor Review. Washington, D. C. (Various issues).

116. U. S. News and World Report. "Forecast of Experts: Prosperity in the $\mathbf{8 0 \mathrm { s }}$. February 11, 1980.

117. U. S. News and World Report. "Tomorrow: A Look Ahead From the Nation's Capital". September 10, 1979.

118. U. S. News and World Report. "What's Up, Down in Living Costs?" February 11, 1980.

119. U. S. Water Resources Council. The Nation's Water Resources. Vol. 1: Summary. Washington, D. C. December 1978 .

120. United States Water Resources Council. 1972 OBERS

$\frac{\text { Projections; Economic Activity in the United States. }}{\text { Vols. 1-5. Washington, D. C. April 1974. }}$

121. University of California. Cooperative Extension Service. Western Livestock Roundup. February 1980.

122. University of California Extension Service. "New Crops for California Agriculture". Syllabus for Conference held February 7, 1980, University of California, Davis. (Typewritten).

123. Wardlow, J., Senior Land and Water Use Analyst, Land and Water Use Section, Environmental Measurement Branch, California Department of Water Resources. (Personal Communication). December 1979.

124. Wall Street Journal. "More Inflation Is Seen, But Many Economists Voice Optimisum On The '80s". December 21 , 1979.

125. Wall Street Journal. "Most Analysts Expect Slow Growth and Drop in Inflation in the 1980s". September 13, 1979.

126. Watson, W. D., Nuckton, C. F., and Howitt, R. E. Crop Production and water Supply Characteristics of Kern County. University of California, Davis. Department of Agricultural Economics. Working Paper No. 78-13. 1978 .

127. Wells Fargo Bank. "California to 1990: State Economic Forecast". San Francisco. March 1978.

128. Western Water. Western Water Education Foundation. Sacramento. November/December 1979. 


\section{GLOSSARY}

Animal unit month (AUM): the amount of feed or forage required by one mature cow for one month. AUM is often referred to as a measure of rangeland or pasture productivity.

By-product feeds: crop or animal food processing residues that are fed to livestock or poultry. Examples are meat processing scraps, sugar beet pulp, and cottonseed meal.

Coefficients of determination $\left(\mathrm{R}^{2}\right)$ : a measure of how well the regression equation fits the actual data. Coefficients of determination are, by definition, numerical values between 0 and 1. For example, a perfect fit estimated between rainfall (dependent variable) and month (independent variable) would have a coefficient of determination of 1.0 , which implies that all variation in rainfall throughout the year is explained by the month of the year (or season) in which it occurs. A coefficient of determination of 0 indicates that there is no relationship between rainfall and month (or season). Causality is not necessarily implied by high coefficients of determination; for example, the fact that the month is January does not cause rain to fall.

Competitive position: the relative profitability of a given productive enterprise in one region, compared to those of other regions, when all costs of production and marketing are included.

Constraints: limits of available productive resources or minimum levels of productive activity, as specified mathematically in mathematical programming models.

Controlled (or prescribed) burning: a method of vegetative management in which rangeland is purposely burned to clear out unwanted trees and brush.

Cow-calf operations: a type of livestock enterprise in which brood cows graze year-around on pasture or rangeland. Their calves are usually sold at weaning time (generally about 8 months of age).

Dependent variables: variables that depend on another (independent) variable. For example, occurrence of rainfall depends on climate and season.

Fed cattle: cattle that have been kept in feedlots before slaughter.

Feed grain concentrates: feeds that are relatively low in fiber and high in digestible nutrients. They supply primary nutrients (protein, carbohydrate, and fat). Examples are grains, cottonseed meal, and wheat bran. 
Feeder cattle: cattle considered to be ready to enter feedlots.

High-protein feeds: feed concentrates or roughage provided in an animal's ration specifically to supply protein.

Input substitutions: the use of different techniques or products to produce the same result. For example, herbicide application may be substituted for weeding by hand.

Linear programming: application of a mathematical procedure that makes the most desirable use of a mathematically expressed objective (for example, profit maximization), where input resource choices (for example, water availability) are limited. Both the objective and the resource choices are expressed as linear equations (see Mathematical programming).

Mathematical modeling: a method of analysis in which relationships between inputs (or decision variables) and outputs (or consequences) are generalized and quantified so that consequences of decision variables can be predicted.

Mathematical programming: application of any of several mathematical procedures to optimization problems. Mathematical

programming, a more general term than linear programming, includes both 1 inear and nonlinear types of models.

Matrices (matrix, singular): rectangular arrays of numbers arranged in rows and columns. Linear programming (and most other types of mathematical programming models) are nearly always set up in this form and are referred to as matrices or tableaus.

Model activities: productive economic activities specified in a model. For example, barley growing is an activity specified in the linear programming model presented in this report.

Nonfed beef: beef derived from cattle which have spent their lives entirely on range or pasture land or in a dairy operation. In either case, the animals are not specifically fed to gain weight.

Objective functions: the mathematical expression of objectives specified in linear or other mathematical programming models. In economic applications, the objective function is usually either cost minimization or profit maximization.

Opportunity costs: the costs of engaging in one activity in relation to the costs of engaging in the next best alternative activity. Opportunity cost is the cost of making decisions, and it relates to a specific time and space. For example, once the decision has been made to grow corn at a given time on a given piece of land that is also suited to the raising of tomatoes, the opportunity cost of growing corn on that piece of 1 and is the difference between the profit to be 
gained from growing corn and the profit to be gained from growing tomatoes. Opportunity costs may be positive, negative, or zero. In the case cited here, if tomatoes are assumed to be the more profitable crop to grow than is corn, the opportunity cost of growing corn is negative.

Optimal production: the level of production in which the entrepreneur maximizes profits or minimizes costs of production.

Parameters: in linear programming, constants in the equations. For example, in the relationship $y=3 x+2$, the numbers 3 and 2 are parameters.

Sensitivity analysis: in linear programming models, that range in production input values in which no change occurs in the optimal model output solution.

Simultaneous equations: a collection of equations considered to be a set of joint conditions imposed on the variables involved.

Standard errors of regression estimates: indications of how far and with what degree of confidence an actual data value could be expected to deviate from the value predicted by a regression equation. For example, the standard error of the regression estimate between rainfall and month of the year (or season) may be plus or minus 10 centimetres at the 95 percent confidence level. That is to say, 95 times out of 100 actual rainfall would be expected to occur within 10 centimetres of rainfall, as predicted by a regression equation relating rainfall (dependent variable) to month of the year (independent variable).

Stocker cattle: weaned beef animals before they enter a feedlot or a breeding herd.

Tableau: a tabular representation of a matrix of a mathematical programming problem. The activities, the objective function, and the input-output production relationships and constraints are expressed in rows and columns.

Technical coefficients: relationships between inputs used to produce a good and the good being produced. For example, if a farm uses $100 \mathrm{kilograms}$ of fertilizer per hectare of corn grown, the technical coefficient of fertilizer per hectare is 100 .

Total digestible nutrients (TDN): the total of all digestible organic nutrients (adjusted for energy value) found in a specified quantity of feed. TDN is generally expressed as a percentage of the total weight of the feed.

Transshipment models: generally considered to be specific types of linear programming models in which a mathematically specified transportation network is an important part of the model design. 
Several assumptions were made and relationships specified concerning the objective function costs, the activities, and the constraints in the model. More specific details of the physical and economic relationships in the 1 inear programming model are given in Tables 15 through 18 .

\section{Objective Function Costs}

1. Land costs are excluded from costs of production. This is because all fixed costs, including land costs, are variable in the long run.

2. Total Digestible Nutrients (TDN) for by-products is a weighted average of TDN for each by-product from the University of California [68]. The low-protein by-products specified are orange rind pulp, sugar beet pulp, molasses, and mill feeds.

3. Rail transportation costs for grains are based on information from the Federal-state Market News Service [64] and Grain Market Summaries [21]. These statistics were used to check the rail cost function, $\mathrm{TC}=25.78+$ $.15869 x$ [69], where: $x=$ number of kilometres hauled and $\mathrm{TC}=$ cents per hundred kilograms. The results obtained by using this cost function were very close to cost statistics available on corn shipped to California from Omaha, Nebraska [64].

4. Truck transportation costs for grains and hay were obtained from the University of California [47] and are increased 19 percent from 1976 to 1978 , using the Consumer Price Index [115].

5. Truck transportation costs for live feeder cattle are based on information from the cooperative Extension Service, University of California [44]. These costs are also assumed for refrigerated poultry and boxed beef.

\section{Activities in the Matrix}

1. Swine and sheep production are excluded from the model because these commodities have traditionally used relatively few feed grain and water resources as a portion of total California livestock production [68]. 
2. Regions for rest-of-U. S. production are based on centers of production [92]. The population center of the United States was assumed to be St. Louis [111], based on U. S. Bureau of Census data and judgment concerning the southwestward movement of population over time.

3. Regional crop activities chosen in the model are based on percentage of total California production. The sum of production for any one crop over all regions must be at least 85 percent of production for the state. The activities are included in the model if they contribute to the top producing regions to reach this 85 -percent

TABLE 15

1978 FEED AND FORAGE CROP RELATIONSHIPS IN THE LINEAR PROGRAMMING MODEL

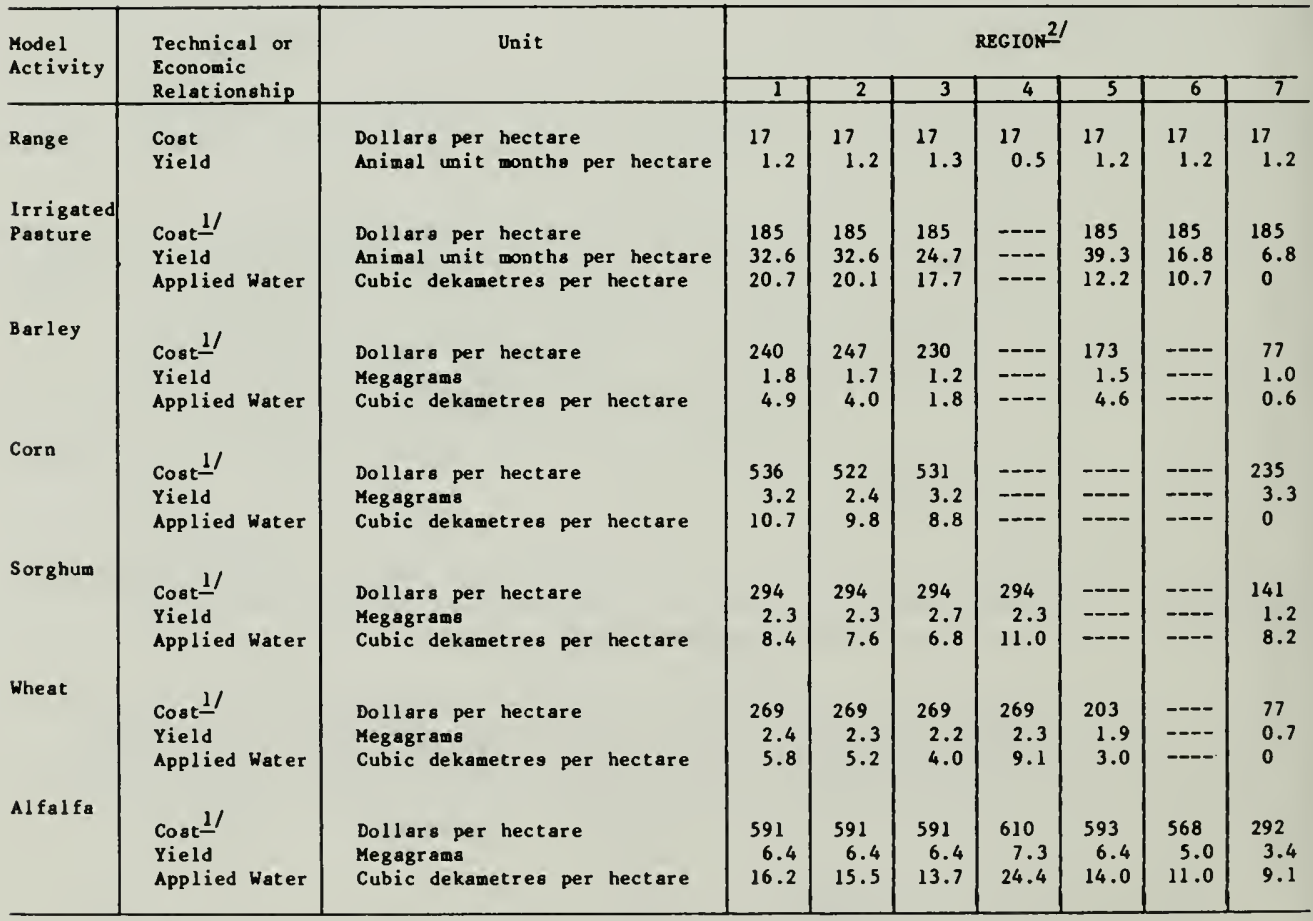

1) Excludes vater.

2) 1 Southern Tulare Lake

Northern Tulare Lake

3 San Joaquin - Sacramento River

Inperial Valley

5 Southern Coastal and Desert

6 Northern California Bay and Mountain

7 Rest of the United States 
goal. Alfalfa and irrigated pasture are defined as activities for all regions because they are high waterusing crops.

4. California's crop production budgets are based on cost of production budgets for the California Agricultural Resources Model (CARM). The regions of the CARM model were modified to $f$ it the regions of the Department of Water Resources (DWR).

5. Animal Unit Months per Hectare for range and irrigated pasture by region are based on data provided by DWR [25]. These were cross-checked with data provided by the University of California [68]. Costs of rangeland per acre of grazing were also provided by University of California data [46].

6. Crop yield data were obtained from the University of California [58] and the U. S. Department of Agriculture (USDA) [92], [102].

TABLE 16

1978 LIVESTUCK AND POULTRY PRODUCTION RELATIONSHIPS IN THE LINEAR PROGRAMMING MODEL

\begin{tabular}{|c|c|c|c|c|c|c|c|c|c|}
\hline \multirow{2}{*}{$\begin{array}{l}\text { Model } \\
\text { Activity }\end{array}$} & \multirow{2}{*}{$\begin{array}{l}\text { Technical or } \\
\text { Economic } \\
\text { Relationship }\end{array}$} & \multirow[t]{2}{*}{ Unit } & \multicolumn{7}{|c|}{ REG[ON1/ } \\
\hline & & & 1 & 2 & 3 & 4 & 5 & 6 & 7 \\
\hline $\begin{array}{l}\text { Inter- } \\
\text { mediate }\end{array}$ & Cost of Production - & Dollars per head & 380 & 380 & 380 & 380 & 380 & 380 & 380 \\
\hline Fed Beef & Forage Consumption & $\begin{array}{l}\text { Animal unit months per } \\
\text { head }\end{array}$ & 18 & 18 & 18 & 18 & 18 & 18 & 18 \\
\hline $\begin{array}{l}\text { Final } \\
\text { Product } \\
\text { Beef }\end{array}$ & Slaughter Costs $2 /$ & Cents per kilogram & 9.3 & 9.3 & 9.3 & 9.3 & 9.3 & 9.3 & 9.3 \\
\hline Broilers & Production Costs $\frac{2 /}{}$ & $\begin{array}{l}\text { Dollars per thousand } \\
\text { birds }\end{array}$ & $\star$ & $\star$ & 71.5 & $\star$ & $\star$ & * & 71.5 \\
\hline Turkeys & Production Costs $2 /$ & $\begin{array}{l}\text { Dollars per thousand } \\
\text { birds }\end{array}$ & * & $\star$ & 213 & $\star$ & $\star$ & $\star$ & 213 \\
\hline Eggs & Production Costs $2 /$ & Dollars per thousand & $\star$ & $\star$ & 27 & $\star$ & * & $\star$ & 27 \\
\hline
\end{tabular}

1/ I Southern Tulare Lake

Northern Tulare Lake

3 San Joaquin - Sacramento River

Imperial Valley

5 Southern Coastal and Desert

6 Northern California Bay and Mountain

7 Rest of the United States

2/ Does not include fixed costs or costs of feed and forage.

* Not applicable in these regions. 
7. Rest-of-U. S. cost of production budgets for crops and livestock were obtained from USDA estimates [100], [101], [102]. These crop budgets were adjusted to be consistent with definitions of California costs of production budgets, where applicable.

8. Alfalfa yields, water use, and costs for Region 7 were obtained from the University of Arizona [65].

9. Water use coefficients for Region 7 feed crops for appropriate production centers were obtained from USDA data $[102]$.

10. Feed crop acreages grown for nonfeed purposes are assumed to be in accordance with data from the University of California [68] for 1974-76. Proportions

TABLE 17

1978 CALIFORNIA INTRASTATE TRUCK TRANSPORTATION COSTS IN THE LINEAR PROGRAMMING MODEL

Total Alfalfa

Transportation Costs

Distance (Kilometres) (Dollars per $1000 \mathrm{kilograms)}$
Total Grain Transportation Costs (Dollars per 1000 kilograms)
$0-80$

160

240

320

400

480

560

640

720

800

880

960
8.60

10.80

12.60

15.40

17.00

19.60

21.60

22.50

24.70

26.40

28.40

30.40
4.80

6.40

8.40

11.00

12.80

14.80

17.20

19.20

20.90

22.70

24.50

26.20 
of nonfeed uses to total crop production are assumed to apply in 1978 and projected years.

11. High-protein feeds are assumed to be available without restriction and are assumed to be a weighted average of cotton and soybean meal in proportion to current estimated use levels.

12. Livestock and poultry rations and production were obtained from the University of California [46], [68].

13. Cost of California livestock and poultry production are based on information from the University of California [46].

TABLE 18

1978 INTERSTATE TRUCK TRANSPORTATION COSTS

IN THE LINEAR PROGRAMMING MODEL

(Live and Refrigerated Livestock and Poultry Products)

\begin{tabular}{|c|c|c|c|c|}
\hline \multicolumn{2}{|c|}{$\begin{array}{c}\text { Distance } \\
\text { (kilometres) } \\
\end{array}$} & \multirow{2}{*}{$\begin{array}{c}\text { Total Dollars } \\
\text { Per } 1000 \text { kilograms } \\
6.90\end{array}$} & \multirow{2}{*}{$\begin{array}{c}\begin{array}{c}\text { Distance } \\
\text { (kilometres) }\end{array} \\
1120\end{array}$} & \multirow{2}{*}{$\begin{array}{c}\begin{array}{c}\text { Total Dollars } \\
\text { Per } 1000 \text { kilograms }\end{array} \\
48.60\end{array}$} \\
\hline 0 & -80 & & & \\
\hline & 160 & 10.10 & 1280 & 54.60 \\
\hline & 240 & 13.40 & 1440 & 60.50 \\
\hline & 320 & 16.80 & 1600 & 66.50 \\
\hline & 400 & 20.10 & 1760 & 72.40 \\
\hline & 480 & 23.40 & 1920 & 78.40 \\
\hline & 560 & 26.70 & 2080 & 84.40 \\
\hline & 640 & 30.00 & 2240 & 90.30 \\
\hline & 720 & 33.40 & 2400 & 96.30 \\
\hline & 800 & 36.68 & 2500 & 102.20 \\
\hline & 880 & 39.70 & 2720 & 108.20 \\
\hline & 960 & 42.60 & 2880 & 114.20 \\
\hline & 1040 & 45.60 & 3040 & 120.10 \\
\hline
\end{tabular}


14. Several livestock relationships are assumed:

(a) Cattle are fed to 500 kilograms and slaughtered at 60 -percent efficiency.

(b) Nonfed cattle are slaughtered at 360 kilograms and 60 -percent efficiency.

(c) Average life of dairy and beef cows is 2.2 years and 4.0 years, respectively [68].

(d) Feed costs represent 85 percent of feeding beef cattle.

\section{Constraints}

1. Crop by-products are available within regions of California in accordance with current use practices, based on present levels of livestock and poultry production and amounts of by-products fed in rations [68].

2. U. S. per capita consumption for 1976-78 are used for Region 7 (Rest-of-U. S.). California per capita consumption for Regions 5 and 6 are based on U. S. consumption patterns and adjusted for California [67].

3. California population is grouped into either Region 5 (Los Angeles) or 6 (San Francisco), on the basis of proximity to these areas.

4. Thirty percent of beef consumption is nonfed, and 70 percent is fed, in accordance with percentages provided by the University of California [46].

5. Minimum levels of various classes of poultry were assumed to be shipped in and out of the state, on the basis of data for the last 10 years. These assumptions are based on California production figures [19] and U. S. per capita consumption for 1976-78 [104, 107]:

(a) Five percent of total California egg production was shipped out of state.

(b) Forty-five percent of California-consumed broilers were produced in California.

(c) Forty percent of turkeys produced in California are shipped out of state. 
THE DWR LIVESTOCK MODEL

A simplified linear programming tableau, showing the logic of the DWR livestock model, is shown in Figure 28. The activity columns are read across the top of the tableau. This model has two forage crop activities (range and irrigated pasture), one grain crop activity (corn), two livestock activities (grass and grain fed beef), in addition to water, transportation, and slaughter activities for the two regions. The objective function of the model is to minimize the costs of the physical relationships between these activities needed to satisfy specified levels of consumer demand for beef.

Maximum availablity constraints of the model are specified for range, irrigated pasture, corn, water, and soil. Minimum constraints are set for corn (minimum rotational acreage) and final consumer demand for slaughtered beef. The Right-Hand Side (RHS) numbers, the "b's" on the far right side of the table, show the maximum amount of the resource available or the minimum specified consumer demand level to be met.

The technical relationships of the constraints are shown in the rows of the matrix in Figure 28. Other rows are balancing supply and demand. For example, all range demanded must be consumed. All transportion demanded must be consumed. These balancing rows are identified as such under the column heading "Comments" on the far right of the tableau.

The remaining rows are used for what is termed "pooling". pooling in this model means that the least expensive source of feed or forage is used first. After this source is exhausted, the next least expensive source is used to meet the same feed or forage requirement. For example, crop by-products are used for cattle feeding until all by-products available are consumed. Grains are then substituted for the by-products. The pooling and balancing rows sum to zero in the right-hand side column, so amounts supplied are neither in excess nor in deficit.

The coefficients in the tableau show the relationships between column activities and row constraints. The "a" coefficient denote technical relationships in production. For example, the "a" coefficient in the matrix cell row ("Demand water l") and column ("Irrigated Pasture 1") show cubic dekametres of water used to grow one hectare of irrigated pasture in Region 1. 
SOURCES OF PHOTOGRAPHS

$\underline{\text { Page }}$

Cover California Cattlemen's Association (left); Department of Water Resources, No. 1012-103 (center), and No. 4275-11 (right).

xii California Cattlemen's Association

8 Department of Water Resources, No. 1012-131 (top), and No. 4275-9 (bottom).

16 Department of Water Resources, No. 4950-15

56

California Cattlemen's Association

68

Department of Water Resources, No. 4740-20 



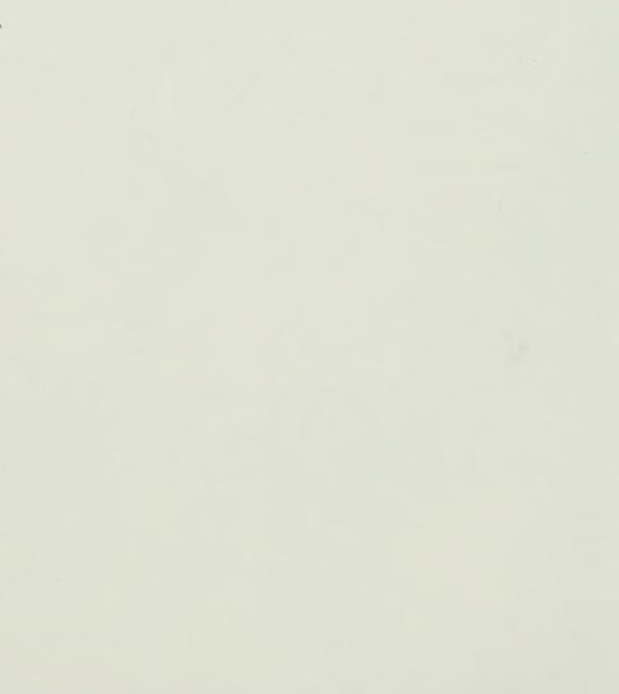




\section{-}


e 28

\section{STOCK MODEL}
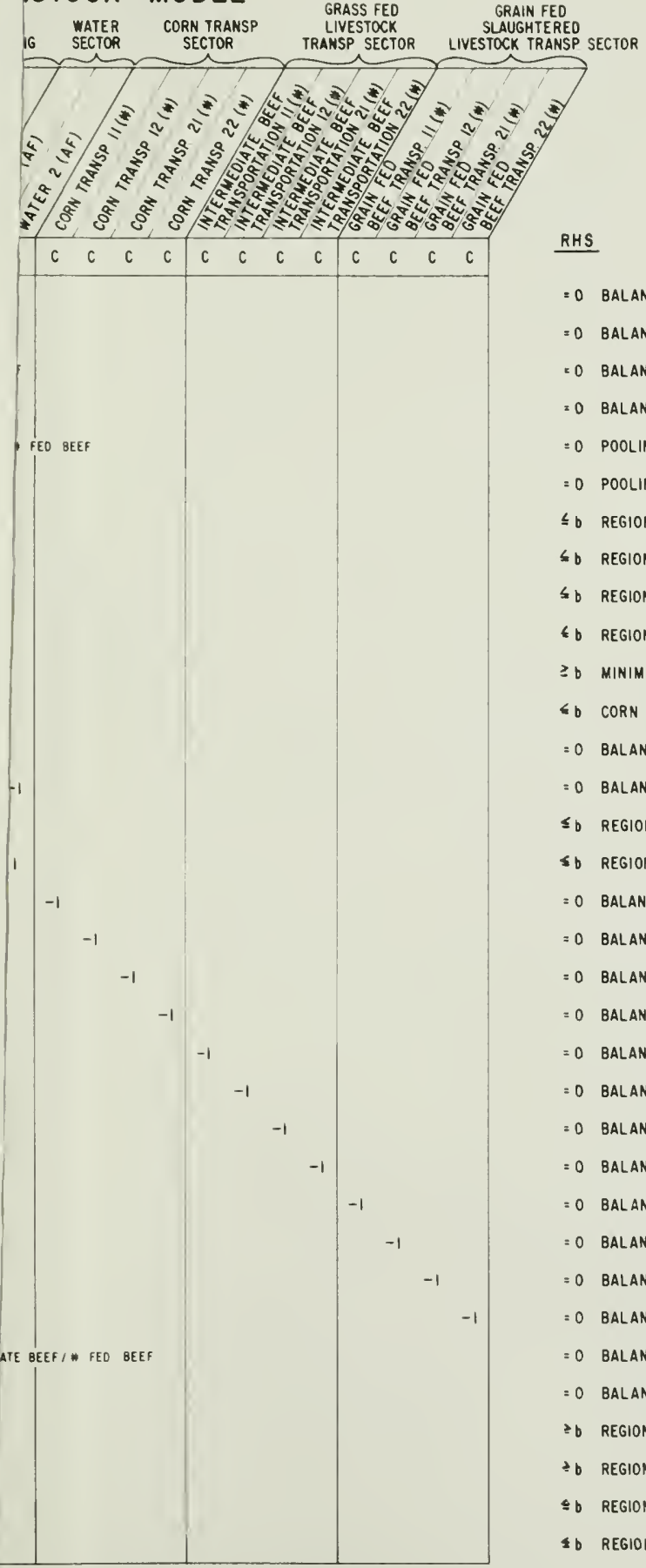

RHS

METRIC CONVERSIONS
I ACRE $\times .40469=$ I HECTARE
IACRE-FOOT \& $1.2335=$ I CUBIC DEKAMETRE
I POUND (\#) $\times .453592=$ I KILOGRAM

COMMENTS

$=0$ BALANCING - RANGE SUPPLIED = RANGE USED

$=0$ BALANCING - RANGE SUPPLIED = RANGE USED

$=0$ BALANCING - IRRIGATED PASTURE SUPPLIED=IRRIGATEO PASTURE USED

$=0$ BALANCING -IRRIGATEO PASTURE SUPPLIED=IRRIGATED PASTURE USEO

$=0$ POOLING - GRAIN FED BEEF HAS TWO SOURCES OF CORN

$=0$ POOLING-GRAIN FED BEEF HAS TWO SOURCES OF CORN

$\leq b$ REgIONAL RANGE CONSTRAINT

$\leqslant b$ REGIONAL RANGE CONSTRAINT

$\leq b$ REgIONAL IRRIGATEO PASTURE CONSTRAINT

\&b REGIONAL IRRIGATED PASTURE CONSTRAINT

$\geq 6$ MINIMUM CORN ACREAGE FOR ROTATIONAL REQUIREMENT

$\because b$ CORN MARKET CONSTRAINT

$=0$ BALANCING - WATER SUPPLIED = WATER USED

$=0$ BALANCING - WATER SUPPLIED = WATER USED

$\leq b$ REGIONAL WATER CONSTRAINT

\b REGIONAL WATER CONSTRAINT

$=0$ BALANCING-CORN TRANSPORTATION SUPPLIED = CORN TRANSPORTATION USEO

$=0$ BALANCING-CORN TRANSPORTATION SUPPLIEO=CORN TRANSPORTATION USED

$=0$ BALANCING - CORN TRANSPORTATION SUPPLIED=CORN TRANSPORTATION USEO

$=0$ BALANCING-CORN TRANSPORTATION SUPPLIEO=CORN TRANSPORTATION USED

$=0$ BALANCING -INTERMEDIATE BEEF TRANSPORTATION SUPPLIED = TRANSP USEO

$=0$ BALANCING -INTERMEDIATE BEEF TRANSPORTATION SUPPLIED = TRANSP USED

$=0$ BALANCING-INTERMEDIATE BEEF TRANSPORTATION SUPPLIED=TRANSP USEO

$=0$ BALANCING-INTERMEDIATE BEEF TRANSPORTATION SUPPLIED $=$ TRANSP USED

$=0$ BALANCING- FED -SLAUGHTERED BEEF TRANSP SUPPLIED = TRANSP USED

$=0$ BALANCING - FEO -SLAUGHTERED BEEF TRANSP SUPPLIED=TRANSP USED

$=0$ BALANCING - FEO -SLAUGHTERED BEEF TRANSP SUPPLIED=TRANSP USED

$=0$ BALANCING - FED -SLAUGHTERED BEEF TRANSP SUPPLIED =TRANSP USED

$=0$ BALANCING - INTERMEDIATE BEEF SUPPLIED = INTERMEDIATE BEEF USED

$=0$ BALANCING-INTERMEDIATE BEEF SUPPLIED = INTERMEDIATE BEEF USED

?b REGIONAL DEMAND FOR FED - SLAUGHTERED BEEF

¿b REGIONAL OEMAND FOR FED - SLAUGHTERED BEEF

\& 6 REGIONAL SOIL AVAILABILITY CONSTRAINT

I G REGIONAL SOIL AVAILABILITY CONSTRAINT 



\section{D.W.R. LIVESTOCK MODEL}

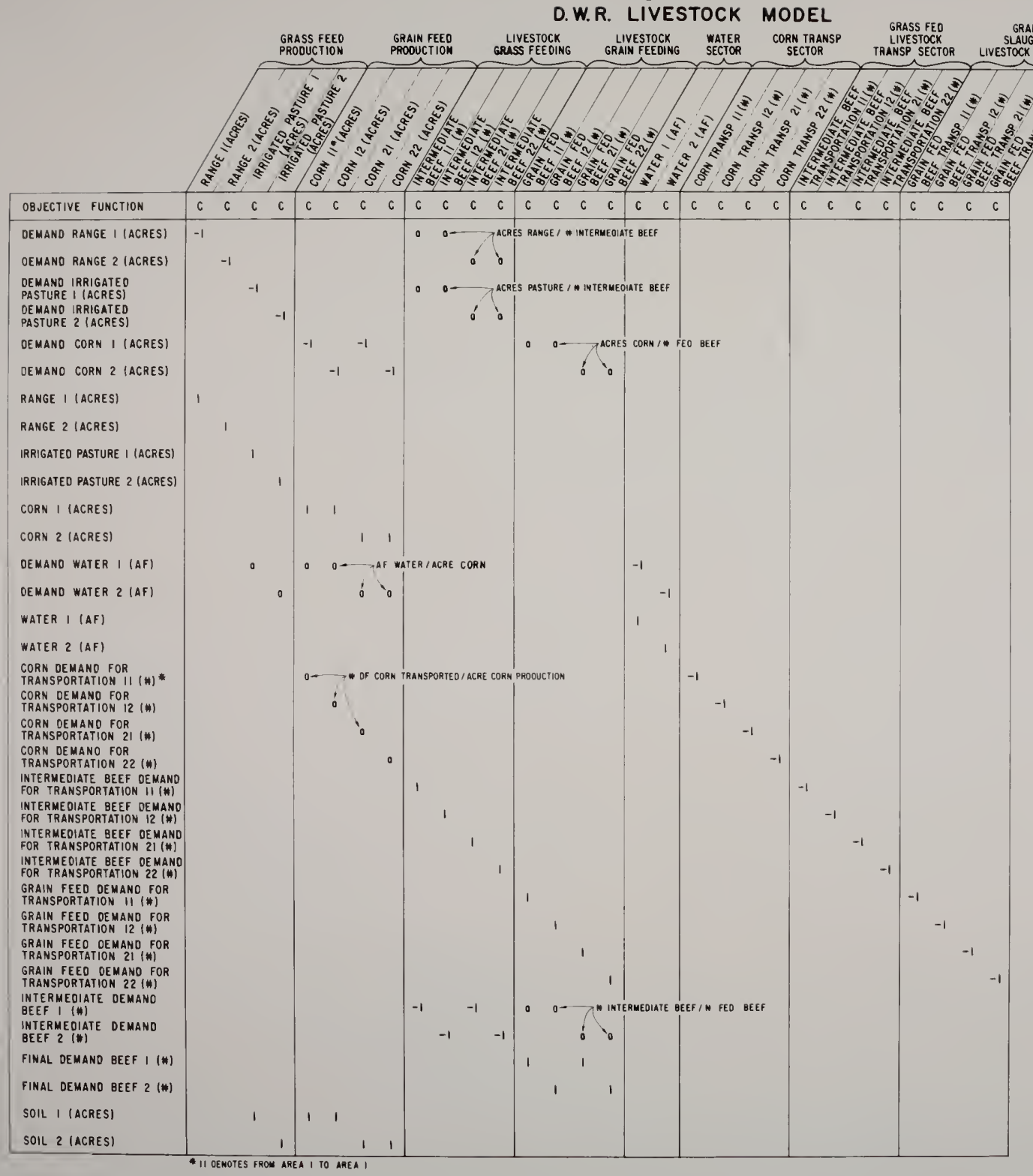

RHS

METRIC CONVERSIONS

I ACRE X. $40469=$ I HECTARE

IACRE - FOOT $\times 1.2335=$ I CUBIC DEKAMETRE

I POUNO (\#) $\times .453592=1$ KILOGRAM

\section{COMMENTS}

$=0$ BALANCING-RANGE SUPPLIED = RANGE USED

$=0$ BALANCING - RANGE SUPPLIED = RANGE USED

-0 BALANCING-IRRIGATEO PASTURE SUPPLIEO=IRRIGATEO PASTGRE USEO

$=0$ BALANCING-IRRIGATEO PASTURE SUPPLIEO=IRRIGATEO PASTURE USEO

$=0$ POOLING - GRAIN FED BEEF HAS TWO SOURCES OF CORN

$=0$ POOLING-GRAIN FEO BEEF HAS TWO SOURCES OF CORN

$\leq b$ REgIONAL RANGE CONSTRAINT

$\leqslant b$ REgIONAL RANGE CONSTRAINT

$\{b$ REGIONAL IRRIGATEO PASTURE CONSTRAINT

\& 6 REGIONAL IRRIGATEO PASTURE CONSTRAINT

$\geq b$ MINIMUM CORN ACREAGE FOR ROTATIONAL REOUIREMENT

$\because b$ CORN MARKET CONSTRAINT

$=0$ BALANCING - WATER SUPPLIED = WATER USEO

= 0 BALANCING - WATER SUPPLIEO = WATER USED

\&b REGIONAL WATER CONSTRAINT

$\checkmark b$ REGIONAL WATER CONSTRAINT

$=0$ BALANCING-CORN TRANSPORTATION SUPPLIEO = CORN TRANSPORTATION USED

= 0 BALANCING-CORN TRANSPORTATION SUPPLIED = CORN TRANSPORTATION USEO

$=0$ BALANCING-CORN TRANSPORTATION SUPPLIED = CORN TRANSPORTATION USED

$=0$ BALANCING-CORN TRANSPORTATION SUPPLIED= CORN TRANSPORTATION USEO

$=0$ BALANCING-INTERMEOIATE BEEF TRANSPORTATION SUPPLIED = TRANSP USED

$=0$ BALANCING-INTERMEDIATE BEEF TRANSPORTATION SUPPLIEO= TRANSP USED

$=0$ BALANCING-INTERMEDIATE BEEF TRANSPORTATION SUPPLIEO=TRANSP USED

= 0 BALANCING-INTERMEDIATE BEEF TRANSPORTATION SUPPLIED = TRANSP USEO

$=0$ BALANCING- FEO -SLAUGHTEREO BEEF TRANSP SUPPLIED = TRANSP USEO

$=0$ BALANCING - FEO -SLAUGHTERED BEEF TRANSP SUPPLIED= TRANSP USEO

$=0$ BALANCING- FED -SLAUGHTEREO BEEF TRANSP SUPPLIEO=TRANSP USEO

$=0$ BALANCING-FED-SLAUGHTERED BEEF TRANSP SUPPLIED=TRANSP USED

$=0$ BALANCING-INTERMEDIATE BEEF SUPPLIEO = INTERMEDIATE BEEF USED

$=0$ BALANCING-INTERMEOIATE BEEF SUPPLIED=INTERMEOIATE BEEF USED

?b REgional oEMANO FOR FEO - SLAUGHTEREO BEEF

? REgional demano FOR FEo - SLAUghtered beEF

\& Regional SOIL aVaILABility CONSTRaINT

4 regional SOIL aVAILABILITY CONSTRAINT 

CONVERSION FACTORS

\begin{tabular}{|c|c|c|c|c|}
\hline Quantity & Ta Convert trom Metric Unit & To Customary Unit & $\begin{array}{l}\text { Multipity Metric } \\
\text { Unit By }\end{array}$ & $\begin{array}{l}\text { To Convert to Metric } \\
\text { Unit Multiply } \\
\text { Customary Unit By }\end{array}$ \\
\hline \multirow[t]{4}{*}{ Length } & millımetres $(\mathrm{mm})$ & inches $\langle$ (n) & 003937 & 254 \\
\hline & centımetres $(\mathrm{cm})$ for snow depth & Inches (ın) & 03937 & 254 \\
\hline & metres $(\mathrm{m})$ & feet $(f t)$ & 32808 & 0.3048 \\
\hline & kılometres $(\mathrm{km})$ & miles (mi) & 0.62139 & 16093 \\
\hline \multirow[t]{4}{*}{ Area } & square millımetres $\left(\mathrm{mm}^{2}\right)$ & square inches $\left(i n^{2}\right)$ & 0.00155 & 645.16 \\
\hline & square metres $\left(\mathrm{m}^{2}\right)$ & square feet $\left(f t^{2}\right)$ & 10764 & 0092903 \\
\hline & hectares (ha) & acres $(a c)$ & 24710 & 040469 \\
\hline & square kılometres $\left(\mathrm{km}^{2}\right)$ & square miles $\left(m i^{2}\right)$ & 03861 & 2.590 \\
\hline \multirow[t]{5}{*}{ Volume } & litres (L) & gallons (gal) & 026417 & 37854 \\
\hline & megalitres & million gallons $\left(10^{6}\right.$ gal $)$ & O 26417 & 37854 \\
\hline & cubic metres $\left(\mathrm{m}^{3}\right)$ & cubic feet $\left(\mathrm{ft}^{3}\right)$ & 35.315 & 0.028317 \\
\hline & cubic metres $\left(\mathrm{m}^{3}\right)$ & cubic yards $\left(y d^{3}\right)$ & 1.308 & 076455 \\
\hline & cubic dekametres $\left(\right.$ dam $\left.^{3}\right)$ & acre-feet $(a c-f t)$ & 08107 & 12335 \\
\hline \multirow[t]{5}{*}{ Flow } & cubic metres per second $\left(\mathrm{m}^{3} / \mathrm{s}\right)$ & $\begin{array}{l}\text { cubic feet per second } \\
\left(\mathrm{ft}^{3} / \mathrm{s}\right)\end{array}$ & 35315 & 0.028317 \\
\hline & litres per minute (L/min) & $\begin{array}{l}\text { gallons per minute } \\
\text { (gal/min) }\end{array}$ & 026417 & 37854 \\
\hline & litres per day (L/day) & gallons per day (gal/day) & 026417 & 3.7854 \\
\hline & megalitres per day (ML/day) & $\begin{array}{l}\text { millıon gallons } \\
\text { per day (mgd) }\end{array}$ & 0.26417 & 37854 \\
\hline & $\begin{array}{l}\text { cubic dekimetres per day } \\
\left(\text { dam }^{3} / \text { day }\right)\end{array}$ & $\begin{array}{l}\text { acre-feet per day (ac- } \\
\text { (t/day) }\end{array}$ & 0.8107 & 12335 \\
\hline \multirow[t]{2}{*}{ Mass } & kılograms (kg) & pounds (Ib) & 22046 & 045359 \\
\hline & megagrams (Mg) & tons (short, 2,000 lb) & 11023 & 0.90718 \\
\hline Velocity & metres per second $(\mathrm{m} / \mathrm{s})$ & feet per second $(\mathrm{ft} / \mathrm{s})$ & 32808 & 0.3048 \\
\hline Power & kılowatts (kW) & horsepower (hp) & 1.3405 & 0.746 \\
\hline \multirow[t]{2}{*}{ Pressure } & kılopascals $(\mathrm{kPa})$ & $\begin{array}{l}\text { pounds per square inch } \\
\left(p s_{1}\right)\end{array}$ & 014505 & 6.8948 \\
\hline & kilopascals (kPa) & feet head of water & 0.33456 & 2.989 \\
\hline Specific Capacity & $\begin{array}{l}\text { litres per minute per metre } \\
\text { drawdown }\end{array}$ & $\begin{array}{l}\text { gallons per minute per } \\
\text { foot drawdown }\end{array}$ & 008052 & 12419 \\
\hline Concentration & milligrams per litre $(\mathrm{mg} / \mathrm{L})$ & parts per million (ppm) & 1.0 & 10 \\
\hline $\begin{array}{l}\text { Electrical Con- } \\
\text { ductivity }\end{array}$ & $\begin{array}{l}\text { microsiemens per centımetre } \\
(\mathrm{uS} / \mathrm{cm})\end{array}$ & micromhos per centimetre & 10 & 1.0 \\
\hline Temperature & degrees Celsius $\left({ }^{\circ} \mathrm{C}\right)$ & degrees Fahrenheit $\left({ }^{\circ} \mathrm{F}\right)$ & $11.8 \times{ }^{\circ} \mathrm{C}$ & $-32\left({ }^{\circ} \mathrm{F}-32\right) / 18$ \\
\hline
\end{tabular}


THIS BOOK IS DUE ON THE LAST DATE STAMPED BELOW

BOOKS REQUESTED BY ANOTHER BORROWER

ARE SUBJECT TO IMMEDIATE RECALL

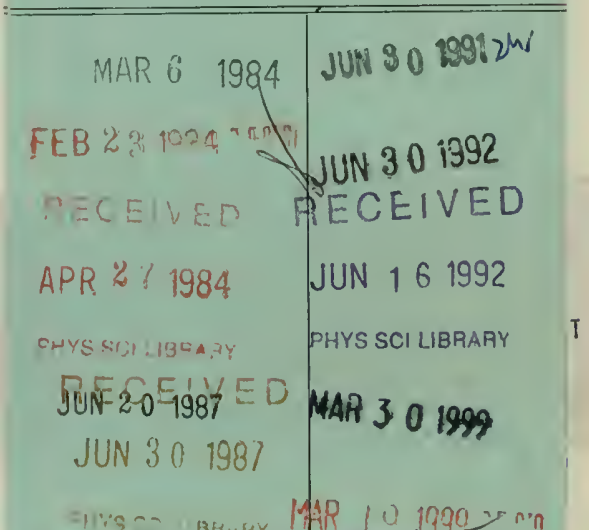

USDA DOC. DELIV. SYSTEMUVIED INTERLIBRARY IOAO

DUE (7) DAYS AFTER PFARIBTL 1999 RPEK EI VISDREC'D

NUV 6 199C EHYS SCI LIBRARY

LIBRARY, UNIVERSITY OF CALIFORNIA, DAVIS 


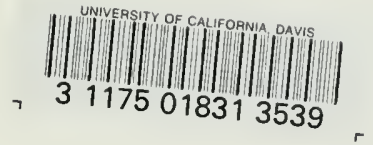



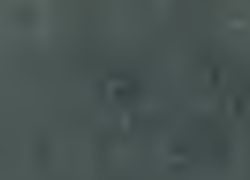